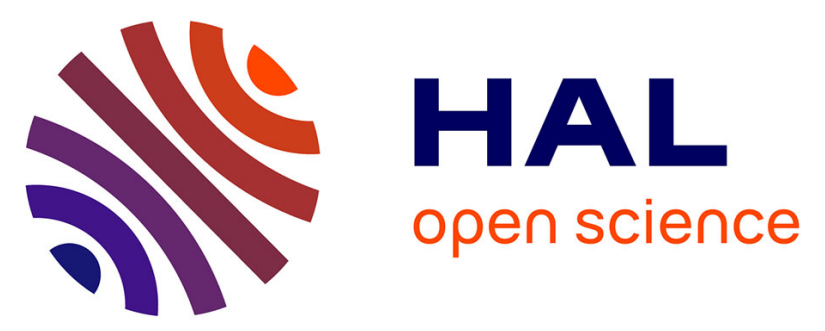

\title{
5-HT2A receptor-dependent phosphorylation of mGlu2 receptor at Serine 843 promotes mGlu2 receptor-operated $\mathrm{Gi} / \mathrm{o}$ signaling
}

\author{
Samy Murat, Mathilde Bigot, Jonathan Chapron, Gabriele M König, Evi
} Kostenis, Giuseppe Battaglia, Ferdinando Nicoletti, Emmanuel Bourinet, Joël Bockaert, Philippe Marin, et al.

\section{To cite this version:}

Samy Murat, Mathilde Bigot, Jonathan Chapron, Gabriele M König, Evi Kostenis, et al.. 5-HT2A receptor-dependent phosphorylation of mGlu2 receptor at Serine 843 promotes mGlu2 receptoroperated Gi/o signaling. Molecular Psychiatry, 2019, 24 (11), pp.1610-1626. 10.1038/s41380-0180069-6 . hal-02356293

\section{HAL Id: hal-02356293 https://hal.science/hal-02356293}

Submitted on 8 Nov 2019

HAL is a multi-disciplinary open access archive for the deposit and dissemination of scientific research documents, whether they are published or not. The documents may come from teaching and research institutions in France or abroad, or from public or private research centers.
L'archive ouverte pluridisciplinaire HAL, est destinée au dépôt et à la diffusion de documents scientifiques de niveau recherche, publiés ou non, émanant des établissements d'enseignement et de recherche français ou étrangers, des laboratoires publics ou privés. 
Research Article

5- $\mathrm{HT}_{2 \mathrm{~A}}$ receptor-dependent phosphorylation of $\mathrm{mGlu}_{2}$ receptor at Serine 843 promotes $\mathrm{mGlu}_{2}$ receptor-operated $\mathrm{G}_{\mathrm{i} / \mathrm{o}}$ signaling

Samy Murat ${ }^{(1-3)}$, Mathilde $\operatorname{Bigot}^{(1-3)}$, Jonathan Chapron ${ }^{(1-3)}$, Gabriele M König ${ }^{(4)}$, Evi Kostenis $^{(4)}$, Giuseppe Battaglia ${ }^{(5)}$, Ferdinando Nicoletti ${ }^{(5,6)}$, Emmanuel Bourinet ${ }^{(1-3)}$, Joël Bockaert $^{(1-3)}$, Philippe Marin ${ }^{\left(1-3^{*}\right)}$, Franck Vandermoere ${ }^{\left(1-3^{*}\right)}$

(1) CNRS, UMR-5203, Institut de Génomique Fonctionnelle, F-34094 Montpellier, France; (2) INSERM, U1191, F-34094 Montpellier, France; (3) Université de Montpellier, F-34094 Montpellier, France; (4) Molecular, Cellular and Pharmacobiology Section, Institute of Pharmaceutical Biology, University of Bonn, 53115 Bonn, Germany; (5) I.R.C.C.S. Neuromed, 86077 Pozzilli, Italy; (6) Department of Physiology and Pharmacology, University Sapienza, 00185 Rome, Italy

$\left.{ }^{*}\right)$ These authors equally contributed to the study

Corresponding authors: Dr Philippe Marin, Institut de Génomique Fonctionnelle, 141 rue de la Cardonille, F-34094 Montpellier Cedex 5, France; Tel +33 4343592 13; Fax + 3346754 24 32; email: philippe.marin@igf.cnrs.fr; Dr Franck Vandermoere, Institut de Génomique Fonctionnelle, 141 rue de la Cardonille, F-34094 Montpellier Cedex 5, France; Tel +33 434 3592 13; Fax + 334675424 32; email: franck.vandermoere@igf.cnrs.fr

Running title: $\mathrm{mGlu}_{2}$ phosphorylation in $5-\mathrm{HT}_{2 \mathrm{~A}} / \mathrm{mGlu}_{2}$ crosstalk 


\begin{abstract}
The serotonin $5-\mathrm{HT}_{2 \mathrm{~A}}$ and glutamate $\mathrm{mGlu}_{2}$ receptors continue to attract particular attention given their implication in psychosis associated with schizophrenia and the mechanism of action of atypical antipsychotics and a new class of antipsychotics, respectively. A large body of evidence indicates a functional crosstalk between both receptors in the brain, but the underlying mechanisms are not entirely elucidated. Here, we have explored the influence of $5-\mathrm{HT}_{2 \mathrm{~A}}$ receptor upon the phosphorylation pattern of $\mathrm{mGlu}_{2}$ receptor in light of the importance of specific phosphorylation events in regulating $G$ protein-coupled receptor signaling and physiological outcomes. Among the five $\mathrm{mGlu}_{2}$ receptor phosphorylated residues identified in HEK-293 cells, the phosphorylation of $\mathrm{Ser}^{843}$ was enhanced upon $\mathrm{mGlu}_{2}$ receptor stimulation by the orthosteric agonist LY379268 only in cells co-expressing the $5-\mathrm{HT}_{2 \mathrm{~A}}$ receptor. Likewise, administration of $\mathrm{LY} 379268$ increased $\mathrm{mGlu}_{2}$ receptor phosphorylation at $\mathrm{Ser}^{843}$ in prefrontal cortex of wild type mice but not $5-\mathrm{HT}_{2 \mathrm{~A}}{ }^{-/}$mice. Exposure of HEK-293 cells co-expressing $\mathrm{mGlu}_{2}$ and $5-\mathrm{HT}_{2 \mathrm{~A}}$ receptors to $5-\mathrm{HT}$ also increased $\operatorname{Ser}^{843}$ phosphorylation state to a magnitude similar to that measured in LY379268-treated cells. In both HEK-293 cells and prefrontal cortex, Ser ${ }^{843}$ phosphorylation elicited by $5-\mathrm{HT}_{2 \mathrm{~A}}$ receptor stimulation was prevented by the $\mathrm{mGlu}_{2}$ receptor antagonist LY341495, while the LY379268-induced effect was abolished by the 5- $\mathrm{HT}_{2 \mathrm{~A}}$ receptor antagonist M100907. Mutation of $\mathrm{Ser}^{843}$ into alanine strongly reduced $\mathrm{G}_{\mathrm{i} / \mathrm{o}}$ signaling elicited by $\mathrm{mGlu}_{2}$ or $5-\mathrm{HT}_{2 \mathrm{~A}}$ receptor stimulation in cells co-expressing both receptors. Collectively, these findings identify $\mathrm{mGlu}_{2}$ receptor phosphorylation at $\operatorname{Ser}^{843}$ as a key molecular event that underlies the functional crosstalk between both receptors.
\end{abstract}




\section{Introduction}

Amongst the 14 5-hydroxytryptamine (serotonin, 5- $\mathrm{HT}$ ) receptor subtypes, the $5-\mathrm{HT}_{2 \mathrm{~A}}$ receptor still raises special interest given its role in the psychotropic effects of psychedelic hallucinogens, which are often used to probe the psychosis associated with schizophrenia, and in the therapeutic effects of atypical antipsychotics like clozapine, olanzapine and risperidone, which act as antagonists or inverse agonists of the receptor $(1,2)$. Atypical antipsychotics are efficient against positive symptoms of schizophrenia (hallucinations, delusions and disorder of thought), but they poorly control negative symptoms (social isolation, anhedonia and inactivity) and are often not efficient against cognitive symptoms (poor "executive functioning", lack of attention, impaired working memory) (3). During the 90ies, a new class of antipsychotics acting as orthosteric agonists (LY354740, LY379268, LY404039) or positive allosteric modulators (PAMs, LY487379, BINA) of group II metabotropic glutamate receptors $\left(\mathrm{mGlu}_{2} / 3\right)$ has been developed. Subsequent preclinical studies indicated that $\mathrm{mGlu}_{2}$ receptor activation accounts for their antipsychotic activity (4-6) and showed overall superiority over $5-\mathrm{HT}_{2 \mathrm{~A}}$ receptor antagonists in alleviating negative symptoms. Furthermore, an integrated study combining five placebo-controlled trials of pomaglumetad, the oral prodrug of LY404039, demonstrated clinical efficacy of glutamatebased pharmacotherapy in schizophrenia in specific patient subgroups, such as patients at early disease stage and, interestingly, patients who had never been treated with $5-\mathrm{HT}_{2 \mathrm{~A}}$ receptor antagonists (7).

5- $-\mathrm{HT}_{2 \mathrm{~A}}$ and $m \mathrm{mGlu}_{2}$ receptors are canonically coupled to $\mathrm{G}_{\mathrm{q}}$ and $\mathrm{G}_{\mathrm{i} / \mathrm{o}}$ proteins, respectively, and thus induce different signaling cascades, but they do not function as independent targets of antipsychotics. Electrophysiological and behavioral studies have demonstrated a functional antagonism between $5-\mathrm{HT}_{2 \mathrm{~A}}$ and $\mathrm{mGlu}_{2}$ receptors: pharmacological activation of $\mathrm{mGlu}_{2}$ receptor inhibits glutamate release and excitatory postsynaptic currents (EPSCs) elicited by $5-\mathrm{HT}_{2 \mathrm{~A}}$ receptor stimulation in the prefrontal cortex, and attenuates behavioral effects of hallucinogens, while $\mathrm{mGlu}_{2}$ receptor antagonists further enhance the frequency and amplitude of $5-\mathrm{HT}_{2 \mathrm{~A}}$ receptor-induced EPSCs $(7,8)$. It has recently been proposed that 
the functional crosstalk between both receptors does not solely occur at the level of neuronal networks or intracellular signaling cascades, but that it involves the formation of $5-\mathrm{HT}_{2 \mathrm{~A}^{-}}$ $\mathrm{mGlu}_{2}$ heteromers, which integrate inputs from ligands of each protomer to trigger unique signaling and behavioral outcomes (9). In vitro and in vivo data identified the $5-\mathrm{HT}_{2 \mathrm{~A}}-\mathrm{mGlu}_{2}$ heterocomplex as a possible target of hallucinogenic $5-\mathrm{HT}_{2 \mathrm{~A}}$ receptor agonists that mediates engagement of $\mathrm{G}_{\mathrm{i} / \mathrm{o}}$ signaling and the associated psychotropic effects (9). Conversely, 5$\mathrm{HT}_{2 \mathrm{~A}}-\mathrm{mGlu}_{2}$ heteromers are necessary for the stimulation of $\mathrm{G}_{\mathrm{q}}$ signaling by $\mathrm{mGlu}_{2}$ receptor agonists, which is altered in patients with schizophrenia (10). This particular signaling also depends on the ability of $m \mathrm{mGlu}_{2}$ receptor to couple to and activate $\mathrm{G}_{\mathrm{i} / \mathrm{o}}$ proteins (10). Finally, studies showed that $5-\mathrm{HT}_{2 \mathrm{~A}}-\mathrm{mGlu}_{2}$ heteromers serve as an integration point that determines the balance between $G_{i / o}$ and $G_{q}$-dependent signaling, and pro-psychotic (increase in $G_{q} v s$. $\mathrm{G}_{\mathrm{i} / \mathrm{o}}$ signaling) vs. antipsychotic (increase in $\mathrm{G}_{\mathrm{i} / \mathrm{o}}$ vs. $\mathrm{G}_{\mathrm{q}}$ signaling) outcome (11). These findings pinpoint the role of $5-\mathrm{HT}_{2 \mathrm{~A}}-\mathrm{mGlu}_{2}$ heteromers in the homeostatic equilibrium between $G_{i / o}$ and in $G_{q}$ signaling that ensures a normal non-psychotic state. However, the existence of $5-\mathrm{HT}_{2 \mathrm{~A}}-\mathrm{mGlu}_{2}$ heteromers and their physiological relevance still remain controversial in absence of unequivocal demonstration of the co-localization of both receptors in neurons (12). There is even predominant evidence for a presynaptic localization of $\mathrm{mGlu}_{2}$ receptors while $5-\mathrm{HT}_{2 \mathrm{~A}}$ receptors are mainly localized at the post-synapse (12).

Given the importance of specific phosphorylation events in determining the signaling and physiological outcomes of G protein-coupled receptors (GPCRs) (13), phosphorylation of 5$\mathrm{HT}_{2 \mathrm{~A}}$ and $\mathrm{mGlu}_{2}$ receptors is another mechanism that might contribute to the functional crosstalk between both receptors, irrespective of heteromer formation. In a previous study, we extensively characterized $5-\mathrm{HT}_{2 \mathrm{~A}}$ receptor phosphorylated sites and identified a serine residue in the third receptor intracellular loop $\left(\operatorname{Ser}^{280}\right)$ phosphorylated in response to receptor activation by hallucinogenic $5-\mathrm{HT}_{2 \mathrm{~A}}$ receptor agonists, such as lysergic acid diethylamide (LSD) or 1-(2,5-dimethoxy-4-iodophenyl)-2-aminopropane (DOI), but not by nonhallucinogenic agonists, such as lisuride or ergotamine (14). This study also showed that the phosphorylation of $\operatorname{Ser}^{280}$ underlies the lower propensity of hallucinogens to induce receptor 
desensitization and internalization, compared with non-hallucinogenic agonists (14). These data suggest that biased phosphorylation of $5-\mathrm{HT}_{2 \mathrm{~A}}$ receptor by hallucinogenic vs. nonhallucinogenic agonists might account for their distinct behavioural outcomes upon long-term treatment. Using an in vitro phosphorylation assay, another study also identified several residues phosphorylated in the $\mathrm{mGlu}_{2}$ receptor $\mathrm{C}$-terminal domain and showed that the phosphorylation of one of them $\left(\mathrm{Ser}^{843}\right)$ by protein kinase $A(\mathrm{PKA})$ affects receptor coupling to $\mathrm{G}$ proteins (15). However, the reciprocal influence of $5-\mathrm{HT}_{2 \mathrm{~A}}$ and $\mathrm{mGlu}$ receptors on their phosphorylation state and the role of their phosphorylation in the functional crosstalk between both receptors remain unexplored.

Here, we characterized phosphorylated residues of $\mathrm{mGlu}_{2}$ receptor expressed in HEK-293 cells and investigated the influence of $5-\mathrm{HT}_{2 \mathrm{~A}}$ receptor expression/stimulation upon their phosphorylation state using high-resolution mass spectrometry. Among the identified residues, we show that $\mathrm{Ser}^{843}$ phosphorylation elicited by agonist stimulation of $\mathrm{mGlu}_{2}$ receptor depends on $5-\mathrm{HT}_{2 \mathrm{~A}}$ receptor co-expression and demonstrate a reciprocal interplay between the activation of both receptors to promote $\mathrm{Ser}^{843}$ phosphorylation. Characterization of the signaling outcome of $\operatorname{Ser}^{843}$ phosphorylation revealed its key role in $\mathrm{G}_{\mathrm{i} / \mathrm{o}}$ signaling elicited by $5-\mathrm{HT}_{2 \mathrm{~A}}$ and $\mathrm{mGlu}_{2}$ receptors agonists in cells co-expressing both receptors. 


\section{Materials and Methods}

\section{Materials}

Human Embryonic Kidney-293 (HEK-293) N type cells (RRID:CVCL_0045) were from the American Type Culture Collection (Anassas, VI, ATCC, CRL-1573). All experiments of the study were performed using a previously characterized batch of cells (Isolate \#3) (16). Their negative mycoplasma status was analyzed every month using the MycoAlert Mycoplasma Detection Kit (Lonza, Switzerland). Culture media were from Invitrogen. M100907 maleate was a generous gift from Dr Jean-Michel Rivet (Institut de Recherches Servier, Croissy-surSeine, France). LY379268 (mGlu 2 receptor orthosteric agonist), LY341495 ( $\mathrm{mGlu}_{2}$ receptor antagonist), KT5720 (PKA inhibitor) and D4476 (casein kinase 1 inhibitor) were from Tocris, lisuride maleate from Santa Cruz Biotechnologies, 5-HT and DOI from Sigma Aldrich. Pertussis Toxin (PTX) was from Calbiochem ${ }^{\circledR}$ and FR900359 was produced as previously described (17).

The rat anti-Hemagglutinin (HA) antibody (11867423001) was from Roche, the rabbit antiFlag antibody (F7425) and the mouse anti-Flag M2 antibody conjugated to magnetic beads (M8823) were from Sigma Aldrich. The rabbit anti-CK1ع (\#12448) was from Cell Signaling and the mouse anti-Actin (\#MA5-11869) was from ThermoScientific. The anti-phospho$\operatorname{Ser}^{843}$ antibody was generated by immunizing rabbits with the synthetic CAAPRAsANLGQG peptide coupled to $\mathrm{KLH}$ (Eurogentec ${ }^{\circledR}$ ). Antibodies were purified by two consecutive affinity chromatographies. A first chromatography against the immobilized phosphorylated CAAPRAsANLGQG peptide as bait bound antibodies recognizing both phosphorylated and unphosphorylated forms of the peptide. The retained fraction was then eluted and used for a second chromatography against the immobilized non-phosphorylated CAAPRASANLGQG peptide. We considered that the non-retained fraction of the second chromatography step contains antibodies recognizing $m \mathrm{mGlu}_{2}$ receptor phosphorylated at $\mathrm{Ser}^{843}$.

The PRK5 plasmid encoding the HA-tagged 5- $\mathrm{HT}_{2 \mathrm{~A}}$ receptor was described elsewhere (18). The cDNA encoding HA-tagged $5-\mathrm{HT}_{2 \mathrm{~A}}\left(\mathrm{D}^{120} \mathrm{~N}\right)$ was generated by site-directed mutagenesis from this plasmid. The pcDNA3 plasmids encoding the Flag-tagged human and rat $\mathrm{mGlu}_{2}$ 
receptors were generously provided by Dr. Philippe Rondard (Institut de Génomique Fonctionnelle, Montpellier, France). The cDNAs encoding human and rat $\mathrm{S}^{843} \mathrm{~A} \mathrm{mGlu}_{2}$ receptors and human $S^{843} \mathrm{D}$ and $\mathrm{S}^{844} \mathrm{~A} \mathrm{mGlu}_{2}$ receptor were obtained by gene synthesis (Eurogentec $^{\circledR}$ ) and subcloned in pcDNA3. The pcDNA3 plasmid encoding human CaV2.2 calcium channel isoform and the single dual promotor plasmid ( $\mathrm{pDuo}$ ) encoding rat $\mathrm{Cava}_{2^{-}}$ $\delta_{1-b}$ and $\operatorname{Cav} \beta_{1 b}$ ancillary subunits cloned in a single dual promotor plasmid (pDuo) were described elsewhere (19). The peGFPC1 plasmid was from Clontech.

\section{Cell cultures and transfection}

HEK-293 cells were grown in Dulbecco's modified Eagle's medium (DMEM) + GlutaMAX (Life Technologies) supplemented with $10 \%$ dialyzed, heat-inactivated fetal calf serum (BioWhittaker) and antibiotics in a humidified $5 \% \mathrm{CO}_{2}$ incubator at $37^{\circ} \mathrm{C}$. They were transfected at $40-50 \%$ confluence using polyethyleneimine (PEI, Sigma-Aldrich), as previously described (20), and used $48 \mathrm{~h}$ after transfection. CKIع siRNA (FlexiTube siRNA CKIE; Cat.N SI00287735 / SI00287728 / SI04434843 / SI04434836) and control siRNA (AllStars Negative Control siRNA; Cat.N 107280) were purchased from QIAGEN. siRNA transfection in HEK-293 cells (at 40-50\% confluence) was performed with Lipofectamine ${ }^{\circledR}$ 2000 (Invitrogen) according to the manufacturer's protocol using a final siRNA concentration of $10 \mathrm{nM}$. Cells were used $48 \mathrm{~h}$ after transfection.

\section{Quantitative mass spectrometry analysis of $\mathrm{mGlu}_{2}$ receptor phosphorylation}

Transfected cells were starved of serum for $4 \mathrm{~h}$, challenged with either vehicle or LY379268 $(1 \mu \mathrm{M})$ for $15 \mathrm{~min}$ and lysed in Triton X-100 (2\%), sodium chloride (150 mM), Tris- $\mathrm{HCl}$ (50 $\mathrm{mM}, \mathrm{pH} 7.5)$, EDTA (2 mM), EGTA (2 mM), SDS (0.2\%), sodium orthovanadate (1 mM), sodium fluoride $(50 \mathrm{mM})$, sodium $\beta$-glycerophosphate $(25 \mathrm{mM})$, sodium pyrophosphate (5 $\mathrm{mM}$ ) and a protease inhibitor cocktail (Roche). The samples were incubated under rotation for $1 \mathrm{~h}$ at $4^{\circ} \mathrm{C}$ and centrifuged for $15 \mathrm{~min}$ at $16,000 \mathrm{xg}$ to eliminate insoluble material. Flagtagged $\mathrm{mGlu}_{2}$ receptor was immunoprecipitated from $10 \mathrm{mg}$ protein extracts using the antiFlag M2 antibody immobilized on magnetic beads. After reduction with dithiothreitol $(10 \mathrm{mM}$, 
$10 \mathrm{~min}$ at $\left.37^{\circ} \mathrm{C}\right)$ and alkylation with iodoacetamide $\left(50 \mathrm{mM}, 45 \mathrm{~min}\right.$ at $\left.25^{\circ} \mathrm{C}\right)$, immunoprecipitated $\mathrm{mGlu}_{2}$ receptors were resolved by SDS-PAGE and digested in-gel with trypsin (10 ng/mL, Gold, Promega) or with chymotrypsin (10 ng/mL, Gold, Promega) overnight at $25^{\circ} \mathrm{C}$. Peptides were analyzed by nano-flow liquid chromatography coupled to Fourier transform tandem mass spectrometry (nanoLC-FT-MS/MS) using a LTQ Velos Pro Orbitrap Elite mass spectrometer coupled to an Ultimate 3000 (Thermo Fisher Scientific). Desalting and pre-concentration of samples were performed on-line on a Pepmap precolumn (0.3 mm $10 \mathrm{~mm}$, Dionex) in buffer A (2\% acetonitrile, $0.1 \%$ formic acid). A gradient consisting of $2-40 \%$ buffer $B$ ( $B=99.9 \%$ acetonitrile with $0.1 \%$ formic acid) (3-33 $\mathrm{min}), 40$ $80 \%$ B (33-34 min), 80-0\% B (49-50 min), and equilibrated for $20 \mathrm{~min}$ in 0\% B (50-70 min) was used to elute peptides at $300 \mathrm{~nL} / \mathrm{min}$ from a Pepmap capillary reversed-phase column (0.075 mm x $150 \mathrm{~mm}$, Thermo Fisher Scientific). Mass spectra were acquired using a top-10 collision-induced dissociation (CID) data-dependent acquisition (DDA) method. The LTQOrbitrap was programmed to perform a FT full scan $(60,000$ resolution) on $400-1,400$ Th mass range with the top ten ions from each scan selected for LTQ-MS/MS with multistage activation on the neutral loss of $24.49,32.66$ and 48.99 Th. FT spectra were internally calibrated using a single lock mass (445.1200 Th). Target ion numbers were 500,000 for FT full scan on the Orbitrap and 10,000 MSn on the LTQ. Precursor mass and top 6 per $30 \mathrm{Da}$ windows peak lists were extracted from MS2 using MSconvert 3.0 and searched with Mascot 2.6 against the human or rat Complete Proteome Set database (http://www.uniprot.org), cysteine carbamidomethylation as a fixed modification and phosphorylation of Ser, Thr and Tyr as variable modifications, $7 \mathrm{ppm}$ precursor mass tolerance, $0.5 \mathrm{Da}$ fragment mass tolerance and trypsin/P or chymotrypsin digestion. MS2 spectra matching phosphorylated peptides with ion score over 15 were manually inspected for unique transitions that pinpoint the position of phosphorylation sites. Ion signals corresponding to phosphorylated peptides were quantified from the maximal intensities measured in their ion chromatograms manually extracted using Qual browser v2.1 (Thermo Fisher Scientific) with a tolerance of $5 \mathrm{ppm}$ for mass deviation, and normalized to signals of their non-phosphorylated counterparts. For 
each identified phosphorylated residue, a phosphorylation index [phosphorylated peptide ion signal intensity / (phosphorylated peptide ion signal intensity + non-phosphorylated peptide ion signal intensity)], was calculated.

\section{Western Blotting}

Proteins, resolved onto $10 \%$ polyacrylamide gels, were transferred electrophoretically to nitrocellulose membranes (Biorad). Membranes were immunoblotted with primary antibodies (anti phospho-Ser ${ }^{843} \mathrm{mGlu}_{2}$ receptor, 1:2,000; anti-Flag, 1:1,000; Anti-HA, 1:1,000) and then with either anti-rat (Jackson ImmunoResearch 112-035-003) or anti-rabbit (Sigma Aldrich GENA934V) or anti-mouse (Sigma Aldrich GENA931V) horseradish peroxidase (HRP)conjugated secondary antibodies (1:5,000). Immunoreactivity was detected with an enhanced chemiluminescence method (Western lightning ${ }^{\circledR}$ Plus-ECL, Perkin Elmer) on a ChemiDoc $^{T m}$ Touch Imaging System (Biorad). Immunoreactive bands were quantified by densitometry using the ImageJ software (v.1.50). In protein phosphorylation analyses, the amount of each phosphoprotein was normalized to the amount of the corresponding total protein detected in the sample.

\section{Analysis of $\mathrm{Ser}^{843}$ phosphorylation in the mouse prefrontal cortex}

Experiments on mice ( $\mathrm{C} 57 / \mathrm{B} / 6 \mathrm{~J}$, eight weeks old, male) conformed to European ethics standards (86/609-EEC) and to decrees of the French National Ethics Committee $\left(\mathrm{N}^{\circ} 87 / 848\right)$ for the care and use of laboratory animals. Protocols were approved by regional ethic committee for animal use (CEEA LR 34, \#7251). A minimum of four animals was used for each group. Animals were randomly allocated into the different groups by an observer who was blind to the experimental conditions. Prior to immunochemistry, brains were randomly numbered in order to perform immunochemistry and image acquisition in a blind way and reassign the samples to their group afterwards. Mice (about $20 \mathrm{~g}$ ) were injected i.p. with either vehicle (5\% DMSO/5\% Tween-80) or LY379268 $(10 \mathrm{mg} / \mathrm{kg})$ or DOI $(10 \mathrm{mg} / \mathrm{kg})$ or lisuride (10 mg/kg). M100907 (5 mg/kg) or LY341495 (3 mg/kg) were injected 15 min prior to vehicle or agonists. LY379268 was also administered to $5-\mathrm{HT}_{2 \mathrm{~A}}{ }^{-1-}(21)$ and $\mathrm{mGlu}_{2}{ }^{-1-}(22)$ mice 
(originally provided by Prof. Shigetada Nakanishi at Kyoto University, Japan), and DOI to $\mathrm{mGlu}_{2}^{-/-}$mice. Thirty min after agonist injection, mice were anesthetized with pentobarbital (100 mg/kg i.p., Ceva SA) and perfused transcardiacally with fixative solution containing $4 \%$ w/v paraformaldehyde, $0.1 \mathrm{M}$ sodium phosphate buffer $(\mathrm{pH} 7.5)$, sodium fluoride $(10 \mathrm{mM})$ and sodium orthovanadate $(2 \mathrm{mM})$. Brains were post-fixed for $48 \mathrm{~h}$ in the same solution and stored at $4^{\circ} \mathrm{C}$. Thirty $\mu \mathrm{m}$-thick sections were cut with a vibratome (Leica). Sections were incubated with a solution containing $0.2 \%$ Triton $\mathrm{X}-100,3 \%$ bovine serum albumin (BSA) and $2 \%$ goat serum in Tris buffer saline (TBS) for $30 \mathrm{~min}$. They were then incubated for $24 \mathrm{~h}$ at $4^{\circ} \mathrm{C}$ with the anti-phospho-Ser ${ }^{843}$ antibody (1:500) in TBS containing 3\% BSA. After four washes, they were incubated for $1 \mathrm{~h}$ with an Alexa Fluor ${ }^{\circledR}$ 488-conjugated anti-rabbit antibody (1:2,000, Invitrogen) in TBS containing 2.5\% BSA and $0.08 \%$ Triton X-100. Immunofluorescent staining was observed with a Zeiss Axioimager Z1 microscope equipped with apotome (Carl Zeiss). Images were acquired using the Zen2 (blue edition) software driving an AxioCam MRm CCD camera (Carl Zeiss). Image analysis was performed with the Image $\mathrm{J}$ software (v1.50) and results were expressed in percentage of anti-phospho-Ser ${ }^{843}$ positive cells relative to DAPI-stained cells.

\section{ELISA}

Quantification of cell surface expression of HA-tagged 5- $\mathrm{HT}_{2 \mathrm{~A}}$ receptors and Flag-tagged wild-type, $S^{843} A$ and $S^{843} \mathrm{D} \mathrm{mGlu}_{2}$ receptors was performed by ELISA under nonpermeabilized conditions, as previously described (23). Dilutions for primary antibodies were 1:400 (Anti-HA) and 1:1,000 (anti-Flag). Secondary antibodies (donkey anti-mouse or antirabbit conjugated to HRP, GE Healthcare) were used at 1:5,000 dilution. Immunoreactive signal was detected with a M200 Infinite plate reader (Tecan), using the SuperSignal ELISA Femto chromogenic substrate (Thermo Scientific). Control experiments were performed using cells transfected with empty vectors.

\section{Electrophysiology}


HEK-293 cells were co-transfected with plasmids encoding Flag-tagged wild-type or $\mathrm{S}^{843} \mathrm{~A}$ or $\mathrm{S}^{843} \mathrm{D}$ mGlu 2 receptor, HA-tagged $5-\mathrm{HT}_{2 \mathrm{~A}}$ receptor, Cav2.2, $\operatorname{Cav} \beta_{1 \mathrm{~b}}$ and $\operatorname{Cav} \alpha_{2}-\delta_{1-\mathrm{b}}$ ancillary subunits and GFP (to detection of transfected cells). Twenty-four hours after transfection, cells were dissociated with Versene (Invitrogen), and plated at low density in poly-ornithinecoated 35-mm Petri dishes for $24 \mathrm{~h}$. Cells were incubated with extracellular solution containing $125 \mathrm{mM} \mathrm{NaCl}, 20 \mathrm{mM}$ TEACl, $10 \mathrm{mM} \mathrm{HEPES}, 5 \mathrm{mM} \mathrm{BaCl}_{2}, 1 \mathrm{mM} \mathrm{MgCl}$ and $\mathrm{pH}$ was adjusted to 7.3 with TEAOH. Borosilicate glass pipettes (2-4 M $\Omega$, Sutter instrument) were filled with internal solution containing $130 \mathrm{mM} \mathrm{CsCl}, 10 \mathrm{mM}$ HEPES, $10 \mathrm{mM}$ EGTA, 2 $\mathrm{mM} \mathrm{CaCl} 2,1 \mathrm{mM} \mathrm{MgCl} 2,4 \mathrm{mM}$ MgATP, $0.3 \mathrm{mM}$ Tris-GTP (pH adjusted to 7.3 with $\mathrm{NaOH}$ ). Currents were elicited from a holding potential of $-80 \mathrm{mV}$ to $0 \mathrm{mV}$ during $10 \mathrm{msec}$ repeated each $1 \mathrm{sec}$. Data were plotted as means \pm SEM. Statistical difference $(p<0.05)$ was determined using one-way analysis of variance.

\section{Statistics}

Statistical analyses were performed using Prism (v. 7.0, GraphPad Software Inc.). Histograms show means \pm SEMs. One-way ANOVA followed by Tukey's and Dunnett's tests were performed for multiple comparisons to multiple groups or to a single group, respectively. For each statistical test, $\mathrm{F}$ value was calculated in order to determine how the variance between the mean values obtained in different populations is significantly different. F value, number of independent biological replicates and sample size (or number of animals per condition) are indicated in the corresponding figure legends. MS peptide identification probabilities were calculated using the Mascot algorithm. Mascot score represents $10 *$ LOG10(p-value), where $p$-value is the absolute probability of peptide wrong assignment. 


\section{Results}

Agonist-stimulated $\mathrm{mGlu}_{2}$ receptor phosphorylation at $\mathrm{Ser}^{843}$ requires co-expression of 5-HT ${ }_{2 \mathrm{~A}}$ receptor in HEK-293 cells

To identify novel molecular substrates of the functional crosstalk between $5-\mathrm{HT}_{2 \mathrm{~A}}$ and $\mathrm{mGlu}_{2}$ receptors, we first examined the phosphorylation pattern of Flag-tagged human $\mathrm{mGlu}_{2}$ receptor co-expressed with $\mathrm{HA}$-tagged $5-\mathrm{HT}_{2 \mathrm{~A}}$ receptor in $\mathrm{HEK}-293$ cells following exposure to vehicle or a maximally-effective concentration of the $\mathrm{mGlu}_{2}$ receptor orthosteric agonist LY379268 (1 $\mu \mathrm{M})(24)$. mGlu 2 receptors were purified by immunoprecipitation followed by SDS-PAGE. They were then digested in-gel with trypsin. Analysis of peptides from vehicle or LY379268-treated cells by nano-flow liquid chromatography coupled to high-resolution tandem mass spectrometry (nano-LC-MS/MS) yielded $57 \%$ coverage of the entire receptor sequence and $75 \%$ coverage of intracellular domains, with a p-value threshold of 0.05 for peptide identification (Supplementary Figure1). LC-MS/MS analysis identified one phosphorylated residue located in the third extracellular domain of the receptor $\left(\mathrm{Thr}^{718}\right)$ and four residues in the C-terminal domain $\left(\operatorname{Ser}^{833}, \operatorname{Ser}^{837}, \operatorname{Ser}^{843 / 844}\right.$ and $\operatorname{Ser}^{871}$, Table 1, Figure 1A, Supplementary Figures 2-5). Note that MS/MS fragmentation did not discriminate between a phosphorylation at $\operatorname{Ser}^{843}$ or $\operatorname{Ser}^{844}$, due to the absence of site-specific fragment ions in MS/MS spectra (Supplementary Figure 4). In an effort to distinguish Ser $^{843}$ from $\mathrm{Ser}^{844}$ phosphorylation, purified $\mathrm{mGlu}_{2}$ receptor was digested with chymotrypsin to generate a proteolytic peptide with the two serine residues located in the central part of the sequence, which should be enriched in discriminant fragment ions. Unfortunately, chymotrypsin digestion yielded only $31 \%$ receptor sequence coverage (Supplementary Figure $6 \mathrm{~A}$ ) and the two theoretically discriminant ions were not detected in the corresponding fragmentation spectra (Supplementary Figure 6B).

Alignment of human, mouse and rat $\mathrm{mGlu}_{2}$ receptor sequences revealed that the region encompassing $\operatorname{Ser}^{843}$ and $\operatorname{Ser}^{844}$ is highly conserved in the three species (Figure 1B). Specifically, $\operatorname{Ser}^{843}$ of the human receptor is conserved in rat and mouse orthologs, whereas $\mathrm{Ser}^{844}$ is replaced by an alanine (Figure 1B). We thus renewed the experiments in cells 
expressing the rat $\mathrm{mGlu}_{2}$ receptor and clearly identified a peptide phosphorylated at $\mathrm{Ser}^{843}$ (Supplementary Figure 7). Consistent with these findings, a peptide comprising phosphorylated $\mathrm{Ser}^{843}$ was likewise identified in cells expressing the $\mathrm{S}^{844} \mathrm{~A}$ mutant of the human $\mathrm{mGlu}_{2}$ receptor (Supplementary Figure 8), while no peptide phosphorylated at Ser ${ }^{844}$ was detected in cells expressing the $\mathrm{S}^{843} \mathrm{~A}$ mutant. Collectively, these results unambiguously identify $\operatorname{Ser}^{843}$ as the phosphorylated residue in the human and murine receptors.

To explore the impact of agonist stimulation of $\mathrm{mGlu}_{2}$ receptor and $5-\mathrm{HT}_{2 \mathrm{~A}}$ receptor expression upon $\mathrm{mGlu}_{2}$ receptor phosphorylation, we next compared the phosphorylation index of each identified phosphorylated residue in cells exposed or not to LY379268, in the presence or absence of $5-\mathrm{HT}_{2 \mathrm{~A}}$ receptor. The phosphorylation index of $\mathrm{Thr}^{718}, \mathrm{Ser}^{833}, \mathrm{Ser}^{837}$ and $\operatorname{Ser}^{871}$ did not display any significant variation upon exposure of cells to LY379268 or coexpression of $5-\mathrm{HT}_{2 \mathrm{~A}}$ receptor (Table 1 and Supplementary Figures 2B, 3B, 5B). In contrast, LY379268 induced a marked increase in $\operatorname{Ser}^{843}$ phosphorylation in cells co-expressing human $\mathrm{mGlu}_{2}$ and $5-\mathrm{HT}_{2 \mathrm{~A}}$ receptors while it did not significantly affect its phosphorylation state in cells expressing $\mathrm{mGlu}_{2}$ receptor alone (Figure 1C). Likewise, LY379268 exposure of cells expressing the rat $\mathrm{mGlu}_{2}$ receptor increased $\mathrm{Ser}^{843}$ phosphorylation only when the 5$\mathrm{HT}_{2 \mathrm{~A}}$ receptor was co-expressed (Figure 1C and Supplementary Figure 7). Collectively, these findings demonstrate that agonist stimulation of $\mathrm{mGlu}_{2}$ receptor induces the phosphorylation of a conserved serine residue in human and murine receptors in HEK-293 cells, an effect dependent of the presence of $5-\mathrm{HT}_{2 \mathrm{~A}}$ receptor.

\section{Agonist-stimulated $\mathrm{mGlu}_{2}$ receptor phosphorylation at $\mathrm{Ser}^{843}$ in the mouse prefrontal cortex requires co-expression of $5-\mathrm{HT}_{2 \mathrm{~A}}$ receptor}

A polyclonal antibody against the $\mathrm{mGlu}_{2}$ receptor phosphorylated at $\operatorname{Ser}^{843}$ was obtained by immunizing a rabbit with the synthetic CAAPRAsANLGQG peptide encompassing a phosphorylated serine residue corresponding to $\mathrm{Ser}^{843}$ in the entire murine receptor. We checked the specificity of the antibody for the phosphorylated site by immunoblotting on HEK-293 cell protein extracts. No immunoreactive signal was observed in blots from cells 
transfected with empty vector, but a clear signal was detected at the expected molecular weight in blots obtained from cells expressing the rat $\mathrm{mGlu}_{2}$ receptor (Supplementary Figure 9). Furthermore, LY379268 treatment strongly enhanced this immunoreactive signal only in cells co-expressing the 5- $\mathrm{HT}_{2 \mathrm{~A}}$ receptor, consistent with the results of MS analysis (Figure 1C and Supplementary Figure 9). Mutation of $\mathrm{Ser}^{843}$ into alanine abolished this immunoreactive signal, confirming the specificity of the antibody for phosphorylated Ser ${ }^{843}$ (Supplementary Figure 9). The maximal signal intensity was reached at LY379268 concentration as low as $1 \mathrm{nM}$ (Supplementary Figure 10A). Notably, expression of $5-\mathrm{HT}_{2 \mathrm{~A}}$ receptor at various densities (in absence of LY379268) did not enhance phosphorylation of $\mathrm{Ser}^{843}$ of $\mathrm{mGlu}_{2}$ receptor (Supplementary Figure 11). As expected, the increase in Ser $\mathrm{r}^{843}$ phosphorylation induced by LY379268 was prevented by the co-application of the $\mathrm{mGlu}_{2}$ receptor antagonist LY341495 (10 $\mu \mathrm{M}$, Supplementary Figure 12). An increase in the antiphospho-Ser ${ }^{843}$ antibody immunoreactivity was also observed in Western blots from cells expressing the human $\mathrm{mGlu}_{2}$ receptor, though the intensity of the immunoreactive signal was much lower than that measured in cells expressing the rat receptor (Supplementary Figure 13), suggesting a higher affinity of our anti-phospho-Ser ${ }^{843}$ antibody for the murine phosphorylated receptor.

We next took advantage of this antibody to investigate the phosphorylation of native $\mathrm{mGlu}_{2}$ receptor in the mouse prefrontal cortex, a brain region where $\mathrm{mGlu}_{2} / 5-\mathrm{HT}_{2 \mathrm{~A}}$ heteromers have been identified (9). We injected mice with either vehicle of LY379268 (10 mg/kg, $30 \mathrm{~min}$ ) and assessed $\mathrm{mGlu}_{2}$ phosphorylation by immunohistochemisty. Reminiscent of the data obtained in HEK-293 cells, LY379268 administration strongly increased immunostaining with the antiphospho-Ser ${ }^{843}$ antibody (Figure 1D). The most intense signal was observed in middle layers of prefrontal cortex, which express the highest density of $5-\mathrm{HT}_{2 \mathrm{~A}}$ receptor (25). As observed in HEK-293 cells, Ser ${ }^{843}$ phosphorylation elicited in mouse prefrontal cortex by injecting LY379268 was also prevented by the administration of LY341495, which alone did not affect $\mathrm{Ser}^{843}$ phosphorylation (Figure 1D). Confirming the specificity of our antibody for phosphorylated $\mathrm{mGlu}_{2}$, no signal was detected in prefrontal cortex of $\mathrm{mGlu}_{2}$ receptor 
knockout $\left(\mathrm{mGlu}_{2}^{-1-}\right)$ mice treated with either vehicle or LY379268 (Figure 1D). Moreover, administration of $\mathrm{LY} 379268$ to $5-\mathrm{HT}_{2 \mathrm{~A}}$ receptor knockout $\left(5-\mathrm{HT}_{2 \mathrm{~A}}{ }^{-\mathrm{l}}\right)$ mice did not increase the phospho-Ser ${ }^{843}$ immunoreactive signal in prefrontal cortex (Figure 1D), indicating that $5-\mathrm{HT}_{2 \mathrm{~A}}$ receptor expression is also necessary for LY379268-induced phosphorylation of native $\mathrm{mGlu}_{2}$ receptor at $\mathrm{Ser}^{843}$.

\section{$\operatorname{Ser}^{843}$ phosphorylation is mediated by casein kinase 1 (CK1)}

In order to identify protein kinase(s) involved in $\mathrm{Ser}^{843}$ phosphorylation, $\mathrm{mGlu}_{2}$ receptor sequence surrounding $\operatorname{Ser}^{843}$ was uploaded into Group-based Prediction System $\left(\right.$ GPS $^{\odot}$, v3.0), a software for kinase consensus search that ranks protein kinases into a hierarchical tree with four levels and builds its algorithm against the PhosphoELM database, in order to calculate false discovery rates for each of them (26). GPS search revealed that $\operatorname{Ser}^{843}$ is a good consensus for phosphorylation by casein kinase 1 (CK1, GPS ${ }^{\odot}$ score 9.3), and cyclic AMP-dependent protein kinase (PKA, GPS ${ }^{\odot}$ score 4.1), consistent with previous findings (15). Pretreatment of HEK-293 cells co-expressing $\mathrm{mGlu}_{2}$ and $5-\mathrm{HT}_{2 \mathrm{~A}}$ receptor with the $\mathrm{CK} 1$ inhibitor D4476 (10 $\mu \mathrm{M}, 60 \mathrm{~min}$ ) (27) abolished LY379268-induced phosphorylation of Ser ${ }^{843}$, whereas the PKA pharmacological inhibitor KT5720 (1 $\mu \mathrm{M}, 60 \mathrm{~min})(28)$ did not affect the level of $\operatorname{Ser}^{843}$ phosphorylation (Figure 2A), suggesting that CK1 rather than PKA promotes $\mathrm{Ser}^{843}$ phosphorylation in living cells. Treatment of cells with D4476 did not affect the low $\mathrm{Ser}^{843}$ phosphorylation level measured in cells expressing $\mathrm{mGlu}_{2}$ receptor alone and challenged with LY379268 (Supplementary Figure 14).

Among the CK1 isoforms, GPS search pointed $\mathrm{CK} 1 \delta$ and $\mathrm{CK} 1 \varepsilon$ as the best candidates able to phosphorylate $\operatorname{Ser}^{843}$. Given the high CK1 $1 \varepsilon$ expression level and the very low expression of CK1 $1 \delta$ in prefrontal cortex (http://mouse.brain-map.org/), we targeted specifically the $\varepsilon$ isoform using RNA interference. Silencing CK1ع expression abolished LY379268-induced $\mathrm{Ser}^{843}$ phosphorylation in cells co-expressing $5-\mathrm{HT}_{2 \mathrm{~A}}$ receptor (Figure $2 \mathrm{~B}$ and Supplementary Figure 15), reminiscent of the effect of cell exposure to D4476 (Figure 2A). 
$G_{i / o}$ and $G_{q}$ proteins are involved in $\operatorname{Ser}^{843}$ phosphorylation elicited by $\mathrm{mGlu}_{2}$ receptor stimulation in cells co-expressing $5-\mathrm{HT}_{2 \mathrm{~A}}$ receptor

In line with the canonical coupling of $\mathrm{mGlu}_{2}$ and $5-\mathrm{HT}_{2 A}$ receptors to $\mathrm{G}_{\mathrm{i} / \mathrm{o}}$ and $\mathrm{G}_{\mathrm{q}}$ proteins, respectively, we next explored their influence on LY379268-induced Ser $^{843}$ phosphorylation in cells co-expressing both receptors. LY379268 exposure did not increase Ser ${ }^{843}$ phosphorylation in cells pretreated with the $\mathrm{G}_{\mathrm{i} / \mathrm{o}}$ inhibitor Pertussis toxin (PTX, $100 \mathrm{ng} / \mathrm{mL}, 18$ h) or the pharmacological $\mathrm{G}_{\mathrm{q} / 11}$ inhibitor FR900359 (1 $\left.\mu \mathrm{M}, 2 \mathrm{~h}\right)(17)$, indicating that the activation of both $G_{i / o}$ and $G_{q / 11}$ is necessary to LY379268-induced $\operatorname{Ser}^{843}$ phosphorylation (Supplementary Figure 16A). Further supporting the role of $G_{q / 11}$ activation by unliganded 5$\mathrm{HT}_{2 \mathrm{~A}}$ receptor, LY379268 exposure did not promote $\mathrm{Ser}^{843}$ phosphorylation in cells expressing the signaling-dead $5-\mathrm{HT}_{2 A}\left(\mathrm{D}^{120} \mathrm{~N}\right)$ receptor (Supplementary Figure 17A) (29).

Agonist-elicited phosphorylation of $\mathrm{mGlu}_{2}$ receptor at $\mathrm{Ser}^{843}$ promotes receptoroperated $G_{i / o}$ signaling

To determine the role of $\mathrm{Ser}^{843}$ phosphorylation in $\mathrm{mGlu}_{2}$ receptor-mediated signal transduction, we measured $\mathrm{mGlu}_{2}$ receptor-operated inhibition of $\mathrm{N}$-type voltage-gated calcium channels, a read-out commonly used to study engagement of $\mathrm{G}_{\mathrm{i} / \mathrm{o}}$ signaling by GPCRs $(30,31)$ (Figure 3A).

As expected, LY379268 inhibited N-type calcium channel-mediated current in a concentration-dependent manner $\left(\mathrm{pEC}_{50}=8.81 \pm 0.16, \mathrm{n}=10\right.$ cells) in HEK-293 cells transiently expressing $\mathrm{mGlu}_{2}$ receptor (Figure 3B). No effect of LY379268 was seen in cells transfected with an empty vector or transiently expressing the $5-\mathrm{HT}_{2 \mathrm{~A}}$ receptor alone, but coexpression of 5- $\mathrm{HT}_{2 \mathrm{~A}}$ receptor with $\mathrm{mGlu}_{2}$ receptor increased the amplitude of LY379268induced inhibition of $\mathrm{N}$-type calcium channels without affecting its apparent affinity $\left(\mathrm{pEC} \mathrm{C}_{50}=\right.$ $8.66 \pm 0.07, n=10$ cells, Figure $3 B$ ). In contrast, co-expression of $5-\mathrm{HT}_{2 \mathrm{~A}}$ receptor with $\mathrm{S}^{843} \mathrm{~A}$ $\mathrm{mGlu}_{2}$ receptor mutant did not enhance the LY379268-induced inhibition of N-type calcium channels, while mutation of $\mathrm{Ser}^{843}$ into aspartate, to mimic permanent phosphorylation of this residue, had no consequence on the level of inhibition of the $\mathrm{N}$-type calcium channels by LY379268 (Figure 3C). Furthermore, pre-treatment of cells with the CK1 inhibitor D4476 (10 
$\mu \mathrm{M})$, which prevented $\operatorname{Ser}^{843}$ phosphorylation, also abolished the potentiation of the LY379268 response elicited by $5-\mathrm{HT}_{2 \mathrm{~A}}$ receptor expression in cells co-expressing wild type $\mathrm{mGlu}_{2}$ receptor but not in cells co-expressing $\mathrm{S}^{843} \mathrm{D} \mathrm{mGlu}_{2}$ receptors (Figure $3 \mathrm{C}$ ). D4476 exposure did not affect the amplitude of LY379268-induced inhibition of $\mathrm{N}$-type calcium channels in cells expressing $\mathrm{mGlu}_{2}$ receptor alone (Figure $3 \mathrm{C}$ ). Collectively, these results suggest that $\operatorname{Ser}^{843}$ phosphorylation is a necessary step of the potentiation of $\mathrm{mGlu}_{2}$ receptor-operated $\mathrm{G}_{\mathrm{i} / \mathrm{o}}$ signaling induced by $5-\mathrm{HT}_{2 \mathrm{~A}}$ receptor expression. This potentiation was not due to an enhanced expression of $\mathrm{mGlu}_{2}$ receptor at the plasma membrane, as ELISA experiments showed that co-expression of $5-\mathrm{HT}_{2 \mathrm{~A}}$ receptors did not change the cell surface expression of $\mathrm{mGlu}_{2}$ receptor (Supplementary Figure 18). Further supporting the absence of influence of $\mathrm{Ser}^{843}$ phosphorylation on $\mathrm{mGlu}_{2}$ receptor plasma membrane localization, wild type, $\mathrm{S}^{843} \mathrm{~A}$ and $\mathrm{S}^{843} \mathrm{D} \mathrm{mGlu}_{2}$ receptors exhibited similar cell surface expression (Supplementary Figure 18).

\section{$5-\mathrm{HT}_{2 \mathrm{~A}}$ receptor stimulation promotes phosphorylation of $\mathrm{mGlu}_{2}$ receptor at $\mathrm{Ser}^{843}$}

Exposure of HEK-293 cells co-expressing $\mathrm{mGlu}_{2}$ and 5- $\mathrm{HT}_{2 \mathrm{~A}}$ receptors to 5-HT increased $\mathrm{Ser}^{843}$ phosphorylation state in a concentration-dependent manner and to a magnitude similar to that measured in LY379268-treated cells (Figures 1C and 4A, Supplementary Figure $10 \mathrm{~B}$ ), an effect prevented by the $5-\mathrm{HT}_{2 \mathrm{~A}}$ receptor antagonist $\mathrm{M} 100907$ (100 $\mathrm{nM}$, Figure 4A). Reminiscent of the LY379268-induced response, the 5-HT-induced Ser ${ }^{843}$ phosphorylation was strongly reduced in cells expressing the $G_{q}$-dead $5-H T_{2 A}\left(D^{120} N\right)$ receptor (Supplementary Figure 17B). Likewise, the 5-HT-elicited $\operatorname{Ser}^{843}$ phosphorylation was abolished in cells pretreated with FR900359 but it persisted in cells pretreated with PTX (Supplementary Figure 16B). The hallucinogenic 5- $\mathrm{HT}_{2 \mathrm{~A}}$ receptor agonist $\mathrm{DOI}(10 \mu \mathrm{M})$ and the non-hallucinogenic agonist lisuride $(10 \mu \mathrm{M})$ induced increases in $\operatorname{Ser}^{843}$ phosphorylation comparable to that measured in cells challenged with 5-HT (Figure 4B). Furthermore, no additional increase in $\mathrm{Ser}^{843}$ phosphorylation state was measured in cells exposed to both LY379268 and 5- $\mathrm{HT}_{2 \mathrm{~A}}$ receptor agonists (5-HT, DOI or lisuride, Figure 4B). 
Corroborating results obtained in transfected HEK-293 cells, administration of DOI (10 $\mathrm{mg} / \mathrm{kg}, 30 \mathrm{~min}$ ) or lisuride $\left(10 \mathrm{mg} / \mathrm{kg}, 30 \mathrm{~min}\right.$ ) to mice induced elevations of $\mathrm{Ser}^{843}$ phosphorylation in prefrontal cortex similar to those measured in mice injected with LY379268 (Figure 4C). As expected, Ser ${ }^{843}$ phosphorylation elicited by DOI injection was prevented by the administration of M100907, which alone did not affect Ser ${ }^{843}$ phosphorylation (Figure 4C). Collectively, these results indicate that $\operatorname{Ser}^{843}$ phosphorylation can be triggered with similar efficiencies by agonist stimulation of either $5-\mathrm{HT}_{2 \mathrm{~A}}$ or $\mathrm{mGlu}_{2}$ receptors in cells co-expressing both receptor subtypes.

Interestingly, treatment of HEK-293 cells co-expressing 5- $\mathrm{HT}_{2 \mathrm{~A}}$ and $\mathrm{mGlu}_{2}$ receptors with LY341495, which alone did not affect $\operatorname{Ser}^{843}$ phosphorylation, inhibited the 5-HT-induced effect (Figure 5A). Conversely, M100907 prevented the LY379268-induced increase in $\operatorname{Ser}^{843}$ phosphorylation, while it slightly but not significantly decreased basal Ser $\mathrm{S}^{843}$ phosphorylation (Figure $5 \mathrm{~B}$ ). $\mathrm{mGlu}_{2}$ and $5-\mathrm{HT}_{2 \mathrm{~A}}$ receptor ligands induced similar regulations of $\operatorname{Ser}^{843}$ phosphorylation in mouse prefrontal cortex: $\operatorname{Ser}^{843}$ phosphorylation elicited by injecting LY379268 was prevented by the administration of M100907 and, reciprocally, the DOI-induced effect was prevented by the administration of LY341495 (Figure 5C). Collectively, these observations indicate that phosphorylation of $\operatorname{Ser}^{843}$ elicited by the stimulation of $5-\mathrm{HT}_{2 \mathrm{~A}}$ receptor depends on the co-expression of $\mathrm{mGlu}_{2}$ receptor at active conformation and vice versa.

\section{Impact of $5-\mathrm{HT}_{2 \mathrm{~A}}$ receptor activation on $\mathrm{G}_{\mathrm{i} / \mathrm{o}^{-}}$-dependent signaling under the control of $\mathrm{mGlu}_{2}$ receptor}

Given the role of $\mathrm{Ser}^{843}$ phosphorylation in $\mathrm{mGlu}_{2}$ receptor-operated activation of $\mathrm{G}_{\mathrm{i} / \mathrm{o}}$ signaling and the critical influence of the $5-\mathrm{HT}_{2 \mathrm{~A}}$ receptor upon this phosphorylation, we also investigated the effect of $5-\mathrm{HT}_{2 \mathrm{~A}}$ receptor stimulation on $\mathrm{G}_{\mathrm{i} / \mathrm{o}}$ signaling by measuring the activity of $\mathrm{N}$-type calcium channels. In cells expressing $5-\mathrm{HT}_{2 \mathrm{~A}}$ receptor alone, $5-\mathrm{HT}(1 \mu \mathrm{M})$ already induced a weak inhibition of N-type calcium channels (Figure 5D). This inhibition was more pronounced in cells co-expressing wild type or $S^{843} \mathrm{D} m \mathrm{mlu}_{2}$ receptors, but not in cells co-expressing $\mathrm{S}^{843} \mathrm{~A}$ mGlu 2 receptor (Figure $5 \mathrm{D}$ ). Reminiscent of their influence upon 
Ser $^{843}$ phosphorylation, both LY341495 and M100907 prevented LY379268- and 5-HTinduced inhibition of $\mathrm{N}$-type calcium channels (Figure 5E). Collectively, these data suggest a reciprocal interplay between $5-\mathrm{HT}_{2 \mathrm{~A}}$ and $\mathrm{mGlu}_{2}$ receptors in engagement of $\mathrm{G}_{\mathrm{i} / \mathrm{o}}$ signaling, which depends on $\operatorname{Ser}^{843}$ phosphorylation. 


\section{Discussion}

Phosphorylation of GPCRs is classically considered as a mechanism initiating receptor desensitization and $\beta$-arrestin-dependent receptor internalization following sustained agonist exposure (32). More recently, subtle modifications of GPCR phosphorylation at specific sites have emerged as key molecular substrates that determine the nature of GPCR-operated signaling, depending on the ligand (functional selectivity) or the cell type, that can be tailored to meet a specific physiological function (33-38). It has also been suggested that GPCR heteromerization can influence the phosphorylation status of the different heteromer constituents, which in turn modulates signaling and physiological outcome of the heteromer. For instance, a recent study has shown that the RF-amide peptide NPFF, by acting at NPFF 2 receptors, induces a transphosphorylation of Mu-opioid receptor within Mu/NPFF 2 heteromers, a process responsible for a loss of function of Mu receptors and contributing to the tolerance to morphine analgesia induced by NPFF (39). These observations highlight the functional and physiological impact of GPCR phosphorylation within heterocomplexes and underscore the potential of deciphering the phosphorylation events on each subunit of GPCR heteromers to elucidate the mechanism of action of psychotropic drugs. They provided the impetus for the present phosphoproteomics screen aimed at characterizing the influence of $5-\mathrm{HT}_{2 \mathrm{~A}}$ receptor expression and stimulation upon $\mathrm{mGlu}_{2}$ receptor phosphorylation pattern.

We identified three $\left(\operatorname{Ser}^{833}, \operatorname{Ser}^{843}\right.$ and $\operatorname{Ser}^{871}$ ) out of the 12 putative phosphorylated residues $\left(\operatorname{Ser}^{109}, \operatorname{Ser}^{111}, \mathrm{Ser}^{246}, \mathrm{Thr}^{457}, \mathrm{Ser}^{501}, \mathrm{Tyr}^{734}, \mathrm{Tyr}^{745}, \mathrm{Tyr}^{749}, \mathrm{Thr}^{832}, \mathrm{Ser}^{833}, \mathrm{Ser}^{843}\right.$ and $\mathrm{Ser}^{871}$ ) referenced in the PhosphoSitePlus database (http://www.phosphosite.org) and two previously not described phosphorylated sites $\left(\operatorname{Ser}^{718}\right.$ and $\operatorname{Ser}^{837}$ ) in human $\mathrm{mGlu}_{2}$ receptor co-expressed with 5- $\mathrm{HT}_{2 \mathrm{~A}}$ receptor in $\mathrm{HEK}-293$ cells challenged with a mGlu 2 receptor agonist. The absence of manual inspection of MS/MS spectra pinpointing the phosphorylated sites referenced in the PhosphoSitePlus database suggests that the majority of the previously described sites are actually not fully validated, though one cannot rule out 
that the difference between our results and the previously reported ones might reflect the distinct biological samples and experimental conditions used.

Among the five sites identified in the present study, only the phosphorylation of a serine residue $\left(\mathrm{Ser}^{843}\right)$ located in the receptor $\mathrm{C}$-terminal domain and conserved in the human and rat sequences was up-regulated upon agonist receptor stimulation. Moreover, Ser ${ }^{843}$ phosphorylation depended on the co-expression of $5-\mathrm{HT}_{2 \mathrm{~A}}$ receptor. Likewise, phosphorylation of $\mathrm{mGlu}_{2}$ receptor at $\mathrm{Ser}^{843}$ elicited in mice prefrontal cortex by peripheral administration of the $\mathrm{mGlu}_{2}$ receptor agonist LY379268 (assessed by immunohistochemistry using a newly-generated phospho-Ser ${ }^{843}$ antibody) was not seen in $5-\mathrm{HT}_{2 \mathrm{~A}}{ }^{-/}$mice. This result indicates that the joint influence of $5-\mathrm{HT}_{2 \mathrm{~A}}$ and $\mathrm{mGlu}_{2}$ receptors upon $\mathrm{Ser}^{843}$ phosphorylation can be observed on both recombinant receptors and native receptors expressed in prefrontal cortex, a brain structure co-expressing both receptors and important for the behavioral responses to $5-\mathrm{HT}_{2 \mathrm{~A}}$ and $\mathrm{mGlu}_{2}$ receptor ligands $(9,40)$. Intriguingly, 5- $\mathrm{HT}_{2 \mathrm{~A}}$ receptor stimulation by $5-\mathrm{HT}$ promoted $\mathrm{Ser}^{843}$ phosphorylation as efficiently as that induced by $\mathrm{mGlu}_{2}$ receptor stimulation, reminiscent of the transphosphorylation of Mu-opioid receptor elicited by NPFF receptor activation (39). Moreover, $\mathrm{Ser}^{843}$ phosphorylation induced by 5 -HT (or the synthetic $5-\mathrm{HT}_{2 \mathrm{~A}}$ receptor agonist $\mathrm{DOI}$ ) was impaired by the $\mathrm{mGlu}_{2}$ receptor antagonist LY341495, while the LY379268-induced effect was prevented by the 5- $\mathrm{HT}_{2 \mathrm{~A}}$ receptor antagonist M100907, thus demonstrating a positive reciprocal influence of both receptor activities upon $\mathrm{mGlu}_{2}$ receptor phosphorylation at $\mathrm{Ser}^{843}$ in HEK-293 cells and mice prefrontal cortex. Notably, the LY379268-induced $\operatorname{Ser}^{843}$ phosphorylation depends on both $\mathrm{G}_{\mathrm{i} / \mathrm{o}}$ and $\mathrm{G}_{\mathrm{q}}$ activation, whereas the $5-\mathrm{HT}$-induced response is only $\mathrm{G}_{\mathrm{q}}$-dependent. Collectively, these findings suggest that $\operatorname{Ser}^{843}$ phosphorylation can result from two types of allosteric modulation exerted by different active conformations of the $5-\mathrm{HT}_{2 \mathrm{~A}}$ receptor within heteromers: i) an allosteric modulation by unliganded (constitutively active) $5-\mathrm{HT}_{2 \mathrm{~A}}$ receptor of agonist-stimulated $\mathrm{mGlu}_{2}$ receptor (bound to activated $\mathrm{G}_{\mathrm{i} / \mathrm{o}}$ protein) and ii) an allosteric modulation by $5-\mathrm{HT}$-stimulated $5-\mathrm{HT}_{2 \mathrm{~A}}$ receptor that is independent of $\mathrm{mGlu}_{2}$ receptor 
stimulation by its own agonist and of $\mathrm{G}_{\mathrm{i} / \mathrm{o}}$ protein activation. However, one cannot rule out that $5-\mathrm{HT}_{2 \mathrm{~A}}$ receptor-dependent $\mathrm{Ser}^{843}$ phosphorylation can also be induced indirectly, via a 5- $\mathrm{HT}_{2 \mathrm{~A}}$ receptor-operated $\mathrm{G}_{\mathrm{q} / 11}$ signaling pathway. Irrespective of the mechanism underlying $\mathrm{Ser}^{843}$ phosphorylation, our results identify a novel functional crosstalk mechanism between $5-\mathrm{HT}_{2 \mathrm{~A}}$ and $\mathrm{mGlu}_{2}$ receptors at the receptor level. The demonstration of this crosstalk in mouse prefrontal cortex strongly supports the co-localization of at least a fraction of both receptors expressed in this brain area and, possibly, the formation of $5-\mathrm{HT}_{2 \mathrm{~A}}-\mathrm{mGlu}_{2}$ heteromers in vivo.

The difference in signal transduction elicited by hallucinogenic and non-hallucinogenic agonists of the $5-\mathrm{HT}_{2 \mathrm{~A}}$ receptor represents one of the best characterized examples of functional selectivity translated into distinct behaviors $(21,41)$. Furthermore, we previously showed that the two categories of $5-\mathrm{HT}_{2 \mathrm{~A}}$ receptor agonists differ in their capacities to promote $5-\mathrm{HT}_{2 \mathrm{~A}}$ receptor phosphorylation at $\operatorname{Ser}^{280}$ (14). Such a biased phosphorylation was not retrieved for $\operatorname{Ser}^{843}$ : treatment of cells with the hallucinogenic agonist DOI and the nonhallucinogenic agonist lisuride induced comparable increases in $\operatorname{Ser}^{843}$ phosphorylation to that elicited by $5-\mathrm{HT}$. It is thus unlikely that $\mathrm{Ser}^{843}$ phosphorylation underlies the distinct behavioral responses induced by both ligand categories.

Among the two kinases possibly involved in $\operatorname{Ser}^{843}$ phosphorylation suggested by the GPS algorithm, namely CK1 and PKA, our data based on pharmacological inhibitors and CK1 expression silencing suggest that this phosphorylation is mediated by CK1. This contrasts with previous findings, which demonstrated that $\operatorname{Ser}^{843}$ can be phosphorylated in vitro by PKA or following a treatment of cells expressing recombinant $\mathrm{mGlu}_{2}$ receptor with the adenylyl cyclase activator forskolin or cell-permeable cAMP analogs. Hence, CK1 rather than PKA seems to be involved in the more physiological context of agonist $\mathrm{mGlu}_{2}$ receptor stimulation in cells co-expressing $5-\mathrm{HT}_{2 \mathrm{~A}}$ receptors, consistent with the canonical coupling of $\mathrm{mGlu}_{2}$ receptors to $\mathrm{G}_{\mathrm{i} / \mathrm{o}}$ proteins and their ability to inhibit rather than stimulate cAMP production (42). CK1 activity generally depends on its expression level or the expression of 
regulators, which are likely not affected by acute extracellular stimuli $(43,44)$. In light of the well-established formation of $5-\mathrm{HT}_{2 \mathrm{~A}}-\mathrm{mGlu}_{2}$ heteromers, at least in recombinant cells $(9,34)$, we hypothesize that $\mathrm{Ser}^{843}$ might be accessible for $\mathrm{CK} 1$ only in a $\mathrm{mGlu}_{2}$ receptor conformation stabilized by its association with $5-\mathrm{HT}_{2 \mathrm{~A}}$ receptor and agonist stimulation of either $\mathrm{mGlu}_{2}$ or $5-\mathrm{HT}_{2 \mathrm{~A}}$ receptor within the heterocomplex.

Consistent with the localization of $\mathrm{Ser}^{843}$ in $\mathrm{mGlu}_{2}$ receptor C-terminal domain, a region important for coupling to $G$ proteins, several lines of evidence suggest that its phosphorylation is an essential step in engagement of $\mathrm{G}_{\mathrm{i} / \mathrm{o}}$ signaling not only upon $\mathrm{mGlu}_{2}$ receptor activation but also following $5-\mathrm{HT}_{2 \mathrm{~A}}$ receptor activation in cells co-expressing both receptors: i) corroborating previous findings indicating that heteromeric assembly of $\mathrm{mGlu}_{2}$ and $5-\mathrm{HT}_{2 \mathrm{~A}}$ receptors enhances glutamate-elicited $\mathrm{G}_{\mathrm{i} / \mathrm{o}}$ signaling (11), co-expression of 5$\mathrm{HT}_{2 \mathrm{~A}}$ receptor with $\mathrm{mGlu}_{2}$ receptor enhanced LY379268-induced inhibition of $\mathrm{N}$-type channels (used as readout of activation of $\mathrm{G}_{\mathrm{i} / \mathrm{o}}$-dependent signaling) $(30,31$ ), an effect suppressed by mutating $\operatorname{Ser}^{843}$ into alanine; ii) reminiscent of their influence upon $\operatorname{Ser}^{843}$ phosphorylation, the 5- $\mathrm{HT}_{2 \mathrm{~A}}$ receptor antagonist M100907 prevented enhancement of LY379268-induced inhibition of $\mathrm{N}$-type channels induced by the co-expression of $5-\mathrm{HT}_{2 \mathrm{~A}}$ receptor, while the mGlu 2 receptor antagonist LY341495 blocked the 5-HT-evoked response. These findings thus identify $\operatorname{Ser}^{843}$ phosphorylation as a novel molecular substrate underlying the functional crosstalk between $5-\mathrm{HT}_{2 \mathrm{~A}}$ and $\mathrm{mGlu}_{2}$ receptors, which determines the level of $\mathrm{G}_{\mathrm{i} / \mathrm{o}}$ signaling under the control of both receptors. It has been proposed that the balance between $\mathrm{G}_{\mathrm{i} / \mathrm{o}}$ and $\mathrm{G}_{\mathrm{q}}$-dependent signaling determines pro-psychotic vs. antipsychotic activity of $5-\mathrm{HT}_{2 \mathrm{~A}}$ and $\mathrm{mGlu}_{2}$ receptors ligands (11). Given the critical influence of $\mathrm{Ser}^{843}$ phosphorylation level on $\mathrm{mGlu}_{2}$ and $5-\mathrm{HT}_{2 \mathrm{~A}}$ receptor-dependent $\mathrm{G}_{\mathrm{i} / \mathrm{o}}$ signaling, its fine-tuning might be an essential mechanism contributing to the homeostatic balance that ensures a normal non-psychotic state.

In conclusion, the present study identifies $\operatorname{Ser}^{843}$ phosphorylation as an early molecular substrate of the functional crosstalk between $5-\mathrm{HT}_{2 \mathrm{~A}}$ and $\mathrm{mGlu}_{2}$ receptors that determines 
the level of $\mathrm{G}_{\mathrm{i} / \mathrm{o}}$ signaling under the control of both receptors, which itself might be predictive of antipsychotic or pro-psychotic effects of drugs targeting each receptor. Accordingly, the anti-phospho-Ser ${ }^{843}$ antibody developed in this study might be a relevant tool for the screening of potential antipsychotic drugs in preclinical models of schizophrenia. Several studies also reported changes in $5-\mathrm{HT}_{2 \mathrm{~A}}$ and $\mathrm{mGlu}_{2}$ receptors densities in patients with schizophrenia, which might contribute to the pathogenicity of the disease $(9,12,46)$. Though the data show some discrepancies and must be considered cautiously due to the potential impact of antipsychotic drug treatment on $5-\mathrm{HT}_{2 \mathrm{~A}}$ receptor expression, the majority of postmortem studies demonstrate a decrease in cortical $5-\mathrm{HT}_{2 \mathrm{~A}}$ receptor density in patients. In line with these findings and the strong influence of $5-\mathrm{HT}_{2 \mathrm{~A}}$ receptor expression/stimulation on $\mathrm{Ser}^{843}$ phosphorylation, analysis of its phosphorylation status in post-mortem brain of patients with schizophrenia might be of great interest. 


\section{Acknowledgements}

Funding: This work was supported by grants from la Fondation pour la Recherche Médicale, ANR (Contract $\mathrm{n}^{\circ}$ ANR-08-MNPS-0011), CNRS, INSERM and University of Montpellier to PM and FV. EB is supported by the LABEX lon Channel Science and Therapeutics (ICST). Mass spectrometry experiments were carried out using facilities of the Functional Proteomic Platform of Montpellier Languedoc-Roussillon. SM was a recipient of a fellowship from the French Ministry for Research.

Author Contributions: SM performed biochemical and electrophysiology experiments, some LC-MS/MS analyses and participated in manuscript writing. MB and JC performed some biochemical experiments and LC-MS/MS analyses. PM conceived the study, supervised experiments and wrote the manuscript. FV conceived the study, performed LCMS/MS analyses and some biochemical experiments, supervised experiments and wrote the manuscript. JB conceived the study and participated in manuscript writing. EB supervised electrophysiology experiments. GK and EK extracted and purified FR900359 from Ardisia crenata plant. GB and $\mathrm{FN}$ participated in experiments on $\mathrm{mGlu}_{2}^{-{ }^{--}}$mice.

Competing interests: The authors declare that they have no conflict of interest.

Supplementary information is available at MP's website. 


\section{References}

1. Gray JA, Roth BL. Molecular targets for treating cognitive dysfunction in schizophrenia. Schizophr Bull. 2007 Sep;33(5):1100-19.

2. Meltzer HY, Massey BW, Horiguchi M. Serotonin receptors as targets for drugs useful to treat psychosis and cognitive impairment in schizophrenia. Curr Pharm Biotechnol. 2012 Jun;13(8):1572-86.

3. Keefe RSE, Bilder RM, Davis SM, Harvey PD, Palmer BW, Gold JM, et al. Neurocognitive effects of antipsychotic medications in patients with chronic schizophrenia in the CATIE Trial. Arch Gen Psychiatry. 2007 Jun;64(6):633-47.

4. Ellaithy A, Younkin J, González-Maeso J, Logothetis DE. Positive allosteric modulators of metabotropic glutamate 2 receptors in schizophrenia treatment. Trends Neurosci. 2015 Aug;38(8):506-16.

5. Gibert-Rahola J, Villena-Rodriguez A. Glutamatergic drugs for schizophrenia treatment. Actas Esp Psiquiatr. 2014 Oct;42(5):234-41.

6. Fell MJ, McKinzie DL, Monn JA, Svensson KA. Group II metabotropic glutamate receptor agonists and positive allosteric modulators as novel treatments for schizophrenia. Neuropharmacology. 2012 Mar;62(3):1473-83.

7. Kinon BJ, Millen BA, Zhang L, McKinzie DL. Exploratory analysis for a targeted patient population responsive to the metabotropic glutamate $2 / 3$ receptor agonist pomaglumetad methionil in schizophrenia. Biol Psychiatry. 2015 Dec 1;78(11):754-62.

8. Marek GJ, Wright RA, Schoepp DD, Monn JA, Aghajanian GK. Physiological antagonism between 5-hydroxytryptamine(2A) and group II metabotropic glutamate receptors in prefrontal cortex. J Pharmacol Exp Ther. 2000 Jan;292(1):76-87. 
9. González-Maeso J, Ang RL, Yuen T, Chan P, Weisstaub NV, López-Giménez JF, et al. Identification of a serotonin/glutamate receptor complex implicated in psychosis. Nature. 2008 Mar 6;452(7183):93-7.

10. Moreno JL, Miranda-Azpiazu P, García-Bea A, Younkin J, Cui M, Kozlenkov A, et al. Allosteric signaling through an mGlu2 and 5-HT2A heteromeric receptor complex and its potential contribution to schizophrenia. Sci Signal. 2016 Jan 12;9(410):ra5.

11. Fribourg M, Moreno JL, Holloway T, Provasi D, Baki L, Mahajan R, et al. Decoding the signaling of a GPCR heteromeric complex reveals a unifying mechanism of action of antipsychotic drugs. Cell. 2011 Nov 23;147(5):1011-23.

12. Delille HK, Mezler M, Marek GJ. The two faces of the pharmacological interaction of mGlu2 and $5-\mathrm{HT}_{2} \mathrm{~A}$ - relevance of receptor heterocomplexes and interaction through functional brain pathways. Neuropharmacology. 2013 Jul;70:296-305.

13. Butcher AJ, Kong KC, Prihandoko R, Tobin AB. Physiological role of G-protein coupled receptor phosphorylation. Handb Exp Pharmacol. 2012;(208):79-94.

14. Karaki S, Becamel C, Murat S, Mannoury la Cour C, Millan MJ, Prézeau L, et al. Quantitative phosphoproteomics unravels biased phosphorylation of serotonin 2A receptor at Ser280 by hallucinogenic versus nonhallucinogenic agonists. Mol Cell Proteomics MCP. 2014 May;13(5):1273-85.

15. Schaffhauser H, Cai Z, Hubalek F, Macek TA, Pohl J, Murphy TJ, et al. cAMPdependent protein kinase inhibits mGluR2 coupling to G-proteins by direct receptor phosphorylation. J Neurosci Off J Soc Neurosci. 2000 Aug 1;20(15):5663-70.

16. Lefkowitz RJ, Pierce KL, Luttrell LM. Dancing with different partners: protein kinase a phosphorylation of seven membrane-spanning receptors regulates their $G$ proteincoupling specificity. Mol Pharmacol. 2002 Nov;62(5):971-4. 
17. Schrage R, Schmitz A-L, Gaffal E, Annala S, Kehraus S, Wenzel D, et al. The experimental power of FR900359 to study Gq-regulated biological processes. Nat Commun. 2015 Dec 14;6:10156.

18. Bécamel C, Gavarini S, Chanrion B, Alonso G, Galéotti N, Dumuis A, et al. The serotonin $5-\mathrm{HT} 2 \mathrm{~A}$ and $5-\mathrm{HT} 2 \mathrm{C}$ receptors interact with specific sets of PDZ proteins. J Biol Chem. 2004 May 7;279(19):20257-66.

19. Gaillard S, Lo Re L, Mantilleri A, Hepp R, Urien L, Malapert P, et al. GINIP, a Gaiinteracting protein, functions as a key modulator of peripheral GABAB receptormediated analgesia. Neuron. 2014 Oct 1;84(1):123-36.

20. Dubois F, Vandermoere F, Gernez A, Murphy J, Toth R, Chen S, et al. Differential 143-3 affinity capture reveals new downstream targets of phosphatidylinositol 3-kinase signaling. Mol Cell Proteomics MCP. 2009 Nov;8(11):2487-99.

21. González-Maeso J, Yuen T, Ebersole BJ, Wurmbach E, Lira A, Zhou M, et al. Transcriptome fingerprints distinguish hallucinogenic and nonhallucinogenic 5hydroxytryptamine $2 \mathrm{~A}$ receptor agonist effects in mouse somatosensory cortex. J Neurosci Off J Soc Neurosci. 2003 Oct 1;23(26):8836-43.

22. Yokoi M, Kobayashi K, Manabe T, Takahashi T, Sakaguchi I, Katsuura G, et al. Impairment of hippocampal mossy fiber LTD in mice lacking mGluR2. Science. 1996 Aug 2;273(5275):645-7.

23. Chanrion B, Mannoury la Cour C, Gavarini S, Seimandi M, Vincent L, Pujol J-F, et al. Inverse agonist and neutral antagonist actions of antidepressants at recombinant and native 5-hydroxytryptamine2C receptors: differential modulation of cell surface expression and signal transduction. Mol Pharmacol. 2008 Mar;73(3):748-57. 
24. Delille HK, Becker JM, Burkhardt S, Bleher B, Terstappen GC, Schmidt M, et al. Heterocomplex formation of 5-HT2A-mGlu2 and its relevance for cellular signaling cascades. Neuropharmacology. 2012 Jun;62(7):2184-91.

25. Miner L a. H, Backstrom JR, Sanders-Bush E, Sesack SR. Ultrastructural localization of serotonin2A receptors in the middle layers of the rat prelimbic prefrontal cortex. Neuroscience. 2003;116(1):107-17.

26. Xue Y, Ren J, Gao X, Jin C, Wen L, Yao X. GPS 2.0, a tool to predict kinase-specific phosphorylation sites in hierarchy. Mol Cell Proteomics MCP. 2008 Sep;7(9):1598-608.

27. Rena G, Bain J, Elliott M, Cohen P. D4476, a cell-permeant inhibitor of CK1, suppresses the site-specific phosphorylation and nuclear exclusion of FOXO1a. EMBO Rep. 2004 Jan;5(1):60-5.

28. Russo LC, Castro LM, Gozzo FC, Ferro ES. Inhibition of thimet oligopeptidase by siRNA alters specific intracellular peptides and potentiates isoproterenol signal transduction. FEBS Lett. 2012 Sep 21;586(19):3287-92.

29. Sealfon SC, Chi L, Ebersole BJ, Rodic V, Zhang D, Ballesteros JA, et al. Related contribution of specific helix 2 and 7 residues to conformational activation of the serotonin 5-HT2A receptor. J Biol Chem. 1995 Jul 14;270(28):16683-8.

30. Chen W-P, Kirchgessner AL. Activation of group II mGlu receptors inhibits voltagegated $\mathrm{Ca} 2+$ currents in myenteric neurons. Am J Physiol Gastrointest Liver Physiol. 2002 Dec;283(6):G1282-1289.

31. Zamponi GW, Bourinet E, Nelson D, Nargeot J, Snutch TP. Crosstalk between G proteins and protein kinase $\mathrm{C}$ mediated by the calcium channel alpha1 subunit. Nature. 1997 Jan 30;385(6615):442-6. 
32. Premont RT, Gainetdinov RR. Physiological roles of G protein-coupled receptor kinases and arrestins. Annu Rev Physiol. 2007;69:511-34.

33. Reiter E, Ahn S, Shukla AK, Lefkowitz RJ. Molecular mechanism of $\beta$-arrestin-biased agonism at seven-transmembrane receptors. Annu Rev Pharmacol Toxicol. 2012;52:179-97.

34. Nobles KN, Xiao K, Ahn S, Shukla AK, Lam CM, Rajagopal S, et al. Distinct phosphorylation sites on the $\beta(2)$-adrenergic receptor establish a barcode that encodes differential functions of $\beta$-arrestin. Sci Signal. 2011 Aug 9;4(185):ra51.

35. Butcher AJ, Prihandoko R, Kong KC, McWilliams P, Edwards JM, Bottrill A, et al. Differential G-protein-coupled receptor phosphorylation provides evidence for a signaling bar code. J Biol Chem. 2011 Apr 1;286(13):11506-18.

36. Busillo JM, Armando S, Sengupta R, Meucci O, Bouvier M, Benovic JL. Site-specific phosphorylation of CXCR4 is dynamically regulated by multiple kinases and results in differential modulation of CXCR4 signaling. J Biol Chem. 2010 Mar 5;285(10):7805-17.

37. Wisler JW, DeWire SM, Whalen EJ, Violin JD, Drake MT, Ahn S, et al. A unique mechanism of beta-blocker action: carvedilol stimulates beta-arrestin signaling. Proc Natl Acad Sci U S A. 2007 Oct 16;104(42):16657-62.

38. Tobin AB, Butcher AJ, Kong KC. Location, location, location...site-specific GPCR phosphorylation offers a mechanism for cell-type-specific signalling. Trends Pharmacol Sci. 2008 Aug;29(8):413-20.

39. Moulédous L, Froment C, Dauvillier S, Burlet-Schiltz O, Zajac J-M, Mollereau C. GRK2 protein-mediated transphosphorylation contributes to loss of function of $\mu$-opioid receptors induced by neuropeptide FF (NPFF2) receptors. J Biol Chem. 2012 Apr 13;287(16):12736-49. 
40. Moreno JL, Holloway T, Albizu L, Sealfon SC, González-Maeso J. Metabotropic glutamate mGlu2 receptor is necessary for the pharmacological and behavioral effects induced by hallucinogenic 5-HT2A receptor agonists. Neurosci Lett. 2011 Apr $15 ; 493(3): 76-9$.

41. González-Maeso J, Weisstaub NV, Zhou M, Chan P, Ivic L, Ang R, et al. Hallucinogens recruit specific cortical $5-\mathrm{HT}(2 \mathrm{~A})$ receptor-mediated signaling pathways to affect behavior. Neuron. 2007 Feb 1;53(3):439-52.

42. Nicoletti F, Bockaert J, Collingridge GL, Conn PJ, Ferraguti F, Schoepp DD, et al. Metabotropic glutamate receptors: from the workbench to the bedside. Neuropharmacology. 2011 Jun;60(7-8):1017-41.

43. Knippschild U, Gocht A, Wolff S, Huber N, Löhler J, Stöter M. The casein kinase 1 family: participation in multiple cellular processes in eukaryotes. Cell Signal. 2005 Jun 1;17(6):675-89.

44. Yang $Y, X u T$, Zhang $Y$, Qin X. Molecular basis for the regulation of the circadian clock kinases CK1ס and CK1ع. Cell Signal. 2017 Feb 1;31:58-65.

45. El Moustaine D, Granier S, Doumazane E, Scholler P, Rahmeh R, Bron P, et al. Distinct roles of metabotropic glutamate receptor dimerization in agonist activation and G-protein coupling. Proc Natl Acad Sci U S A. 2012 Oct 2;109(40):16342-7.

46. Dean B. The cortical serotonin2A receptor and the pathology of schizophrenia: a likely accomplice. J Neurochem. 2003 Apr;85(1):1-13. 


\section{Figure legends}

Figure 1. Agonist-stimulated $\mathrm{mGlu}_{2}$ receptor phosphorylation at $\mathrm{Ser}^{843}$ requires coexpression of $5-\mathrm{HT}_{2 \mathrm{~A}}$ receptor in $\mathrm{HEK}-293$ cells and mouse prefrontal cortex. A, Schematic overview of the position of phosphorylated residues identified by MS/MS in

human $\mathrm{mGlu}_{2}$ receptor. B, Sequence alignment of the receptor region containing $\mathrm{Ser}^{843}$ in human, mouse and rat $\mathrm{mGlu}_{2}$ orthologs. Note that $\mathrm{Ser}^{843}$ is conserved in the three orthologs, while $\operatorname{Ser}^{844}$ in the human receptor is replaced by an alanine in murine orthologs. The sequences in bold correspond to peptides identified by MS/MS. C, HEK-293 cells transiently expressing human or rat $\mathrm{mGlu}_{2}$ receptor in the absence or presence of $5-\mathrm{HT}_{2 \mathrm{~A}}$ receptor were exposed to vehicle or LY379268 (LY37, $1 \mu \mathrm{M})$ for $15 \mathrm{~min}$. The histograms represent the means \pm SEM of ion signal intensities (expressed in $\%$ of signal intensity measured in cells co-expressing $\mathrm{mGlu}_{2}$ and $5-\mathrm{HT}_{2 \mathrm{~A}}$ receptors and treated with $\mathrm{LY} 379268$ ) measured in three replicates. One-way ANOVA (Post-hoc: Tukey's range test): $F(3,12)=14.91, p=0.0002$ and $F(3,8)=5.558, p=0.0234$, in cells expressing human and rat $m G l u_{2}$, respectively. ${ }^{*} p<0.05$; ${ }^{* *} p<0.01 ;{ }^{* * *} p<0.001$. D, Wild type, $5-\mathrm{HT}_{2 \mathrm{~A}}{ }^{-/-}$and $\mathrm{mGlu}_{2}{ }^{-/-}$mice were injected with either vehicle or LY379268 (10 mg/kg, i.p) for $30 \mathrm{~min}$. LY341495 (3 mg/kg i.p.) was injected $15 \mathrm{~min}$ before vehicle/LY379268 administration. Representative images showing phospho-Ser ${ }^{843}$ $\mathrm{mGlu}_{2}$ immunofluorescent staining in prefrontal cortex are illustrated. The histogram shows the mean \pm SEM of values (expressed in \% of anti-phospho-Ser ${ }^{843}$-positive cells relative to DAPI-stained cells) obtained in four animals per group. One-way ANOVA (Post-hoc: Tukey's range test): $F(5,18)=8.967, p=0.0002$. ${ }^{*} p<0.05 ;{ }^{* *} p<0.01,{ }^{* * *} p<0.001$. Scale bar: $100 \mu \mathrm{m}$. ns: not significant.

Figure 2. 5-HT $2 \mathrm{~A}$ receptor-dependent phosphorylation of $\mathrm{Ser}^{843}$ elicited by LY379268 is mediated by casein kinase 1 . A, HEK-293 cells co-expressing rat Flag-tagged $\mathrm{mGlu}_{2}$ and $\mathrm{HA}$-tagged $5-\mathrm{HT}_{2 \mathrm{~A}}$ receptors were pre-incubated with either vehicle or the CK1 inhibitor (D4476, $10 \mu \mathrm{M})$ or the PKA inhibitor (KT5720, $1 \mu \mathrm{M})$ for $60 \mathrm{~min}$ and then challenged with vehicle or LY379268 (LY37, $1 \mu \mathrm{M})$ for 15 min. B, HEK-293 cells co-expressing Flag-tagged 
rat $\mathrm{mGlu}_{2}$ and $\mathrm{HA}$-tagged $5-\mathrm{HT}_{2 \mathrm{~A}}$ receptors were transfected with either control or $\mathrm{CK} 1 \varepsilon$ siRNA and challenged for 15 min with vehicle or LY379268 (LY37, $1 \mu \mathrm{M})$. Phosphorylation of

$\mathrm{mGlu}_{2}$ receptor at $\mathrm{Ser}^{843}$ was assessed by sequential immunoblotting with the anti-phospho$\mathrm{Ser}^{843}-\mathrm{mGlu}_{2}$ receptor antibody and the anti-Flag antibody. Representative blots of three independent experiments performed on different sets of cultured cells are illustrated. The histograms show the means \pm SEM of the anti-phospho-Ser ${ }^{843} \mathrm{mGlu}_{2}$ receptor immunoreactive signal relative to Flag immunoreactive signal (expressed in arbitrary units, a.u.) obtained in the three experiments. One-way ANOVA (Post-hoc: Tukey's range test): A, $F(5,12)=10.23, p=0.0005 . B, F(3,8)=8.114, p=0.0082 .{ }^{*} p<0.05,{ }^{* *} p<0.01$ vs. corresponding vehicles. ns: not significant.

Figure 3. Potentiation of $\mathrm{mGlu}_{2}$ receptor-operated $\mathrm{G}_{\mathrm{i} / \mathrm{o}}$ signaling elicited by $5-\mathrm{HT}_{2 \mathrm{~A}}$ receptor expression depends on Ser $^{843}$ phosphorylation. A, Schematic overview of $\mathrm{N}$ type calcium channel inhibition elicited upon activation of $\mathrm{G}_{\mathrm{i} / \mathrm{o}^{-}}$-coupled receptors. B, Left panel: representative current traces obtained in response to vehicle (open circles) or $1 \mu \mathrm{M}$ LY379268 (filled circles) in HEK-293 cells expressing Flag-tagged wild type mGlu 2 receptor alone or in combination with HA-tagged 5-HT $2 \mathrm{~A}$ receptor. Right panel: HEK-293 cells, transiently expressing Flag-tagged wild type $\mathrm{mGlu}_{2}$ receptor alone or in combination with HA-tagged 5- $\mathrm{HT}_{2 \mathrm{~A}}$ receptor, were exposed to increasing concentrations of LY379268. Each point represents the means \pm SEM of percentage of $\mathrm{N}$-type calcium channel current inhibition measured in 10 cells from three different sets of cultured cells. C, Left panel: cells, expressing Flag-tagged $\mathrm{mGlu}_{2}$ receptor alone or co-expressing $\mathrm{HA}$-tagged $5-\mathrm{HT}_{2 \mathrm{~A}}$ receptor and either wild type or $S^{843} A$ or $S^{843} D$ Flag-tagged $\mathrm{mGlu}_{2}$ receptor, were exposed to $1 \mu \mathrm{M}$ LY379268. Right panel: HEK-293 cells, expressing Flag-tagged $\mathrm{mGlu}_{2}$ receptor alone or coexpressing $\mathrm{HA}$-tagged $5-\mathrm{HT}_{2 \mathrm{~A}}$ receptor and either wild type or $\mathrm{S}^{843} \mathrm{D} \mathrm{mGlu}_{2}$ receptor, were treated with vehicle or D4476 $(10 \mu \mathrm{M}$, delivered via the patch pipette 5 min before the LY379268 challenge). Representative traces of $\mathrm{N}$-type calcium channel currents in conditions not depicted in B are illustrated. Histograms represent the means \pm SEM of $\mathrm{N}$ - 
type calcium channel current inhibition induced by LY379268 in 10 cells from three independent cultures. One-way ANOVA (Post-hoc: Tukey's range test): $F(3,36)=16.94$, $p<0.0001 ; F(5,54)=17.15, p<0.0001$ in left and right panels, respectively. ${ }^{* *} p<0.001$.

Figure 4. $5-\mathrm{HT}_{2 \mathrm{~A}}$ receptor stimulation promotes phosphorylation of $\mathrm{mGlu}_{2}$ at $\mathrm{Ser}^{843}$ in HEK-293 cells and mouse prefrontal cortex. A, HEK-293 cells co-expressing Flag-tagged $\mathrm{mGlu}_{2}$ receptor and $\mathrm{HA}$-tagged $5-\mathrm{HT}_{2 \mathrm{~A}}$ receptor were exposed to vehicle or $5-\mathrm{HT}(1 \mu \mathrm{M}, 15$ min) in the absence or presence of M100907 (100 nM). B, Cells were exposed to either vehicle or 5 -HT $(1 \mu \mathrm{M})$, or DOI $(10 \mu \mathrm{M})$ or lisuride $(10 \mu \mathrm{M})$ in the absence or presence of LY379268 $(1 \mu \mathrm{M})$ for $15 \mathrm{~min}$. Phosphorylation of $\mathrm{mGlu}_{2}$ receptor at $\mathrm{Ser}^{843}$ was assessed by sequential immunoblotting with the anti-phospho-Ser ${ }^{843}-\mathrm{mGlu}_{2}$ receptor antibody and the anti-Flag antibody. In $A$ and $B$, representative blots of three independent experiments performed on different sets of cultured cells are illustrated. The histograms show the means \pm SEM of anti-phospho-Ser ${ }^{843} \mathrm{mGlu}_{2}$ receptor immunoreactive signal relative to Flag immunoreactive signal (expressed in arbitrary units) obtained in the three experiments. A, One-way ANOVA (Post-hoc: Tukey's range test): $F(2,6)=16.63, p<0.0036$. B, One-way ANOVA (Post-hoc: Dunnett's range test): $F(6,14)=7.779, p<0.0008 .{ }^{*} p<0.05 ;{ }^{* *} p<0.01$; ${ }^{* *} p<0,001$ vs. Vehicle. $\S p<0.05$ vs. 5-HT. C, Wild type mice were injected with either vehicle or DOI (10 mg/kg, i.p) or lisuride (10 mg/kg, i.p). $\mathrm{mGlu}_{2}{ }^{-1-}$ mice were injected with DOI (10 mg/kg, i.p). M100907 (5 mg/kg, i.p.) was injected $15 \mathrm{~min}$ before vehicle/DOI administration. Representative images showing phospho-Ser ${ }^{843}-\mathrm{mGlu}_{2}$ immunofluorescent staining in prefrontal cortex are illustrated. The histogram shows the mean \pm SEM of values (expressed in \% of anti-phospho-Ser ${ }^{843}$-positive cells relative to DAPI-stained cells) obtained in four animals per group. One-way ANOVA (Post-hoc: Tukey's range test): $F(4,15)=33.62$, $p<0.0001 .{ }^{* * *} p<0.001$. Scale bar: $100 \mu \mathrm{m}$. 
Figure 5. Reciprocal influence of $\mathrm{mGlu}_{2}$ and $5-\mathrm{HT}_{2 \mathrm{~A}}$ receptor stimulation upon $\mathrm{G}_{\mathrm{i} / \mathrm{o}}$ signaling depends on Ser $^{843}$ phosphorylation. A, HEK-293 cells co-expressing Flagtagged $\mathrm{mGlu}_{2}$ receptor and $\mathrm{HA}$-tagged $5-\mathrm{HT}_{2 \mathrm{~A}}$ receptor were exposed to vehicle or $5-\mathrm{HT}$ (1 $\mu \mathrm{M})$, alone or in combination with LY341495 $(10 \mu \mathrm{M})$, or to LY341495 alone (10 $\mu \mathrm{M})$ for 15 min. B, HEK-293 cells co-expressing Flag-tagged $\mathrm{mGlu}_{2}$ receptor and $\mathrm{HA}$-tagged $5-\mathrm{HT}_{2 \mathrm{~A}}$ receptor were exposed for $15 \mathrm{~min}$ to vehicle or LY379268 (10 nM), in the absence or presence of M100907 (100 nM). In A and B, mGlu ${ }_{2}$ receptor phosphorylation was analyzed by sequential immunoblotting with the anti-phospho-Ser ${ }^{843}$ antibody and the anti-Flag antibody. Representative blots of three independent experiments performed on different sets of cultured cells are illustrated. The histograms show the means \pm SEM of the anti-phospho$\mathrm{Ser}^{843} \mathrm{mGlu}_{2}$ receptor immunoreactive signal relative to Flag immunoreactive signal (expressed in arbitrary units, a.u.) obtained in the three experiments. One-way ANOVA (Post-hoc: Tukey's range test): $F(3,8)=22.49, p=0.0003$ and $F(3,8)=28.97, p=0.0001$ in $A$ and $B$, respectively. ${ }^{* *} p<0.01,{ }^{* * *} p<0.001$. C, Mice were injected with either DOI $(10 \mathrm{mg} / \mathrm{kg}$, i.p), LY379268 (10 mg/kg, i.p). M100907 (5 mg/kg, i.p.) and LY341495 (3 mg/kg, i.p.) were injected $15 \mathrm{~min}$ before vehicle/LY379268/DOI administration. Representative images showing phospho-Ser ${ }^{843}-\mathrm{mGlu}_{2}$ immunofluorescent staining in prefrontal cortex are illustrated. The histogram shows the mean \pm SEM of values (expressed in $\%$ of antiphospho-Ser ${ }^{843}$-positive cells relative to DAPI-stained cells) obtained in four animals per group. One-way ANOVA (Post-hoc: Tukey's range test): $F(5,18)=24.57, p<0.0001$. ${ }^{* * *} p<0.001$. Scale bar: $100 \mu \mathrm{m}$. D, HEK-293 cells, transiently expressing $5-\mathrm{HT}_{2 \mathrm{~A}}$ receptor alone or in combination with either wild type or $\mathrm{S}^{843} \mathrm{~A}$ or $\mathrm{S}^{843} \mathrm{D} \mathrm{mGlu}$ receptor, were exposed to $1 \mu \mathrm{M} 5-\mathrm{HT}$. Representative traces of $\mathrm{N}$-type calcium channel currents obtained after exposure to vehicle or $5-\mathrm{HT}$ are shown. The histograms represent the means \pm SEM of $\mathrm{N}$ type calcium channel current inhibition measured for each treatment in 10 cells originating from three independent cultures. One-way ANOVA (Post-hoc: Tukey's range test): $F(3,36)=13.45, p<0.0001 .{ }^{* * *} p<0.001$. E, Left panels: HEK-293 cells co-expressing $5-\mathrm{HT}_{2 \mathrm{~A}}$ and $\mathrm{mGlu}_{2}$ receptors were sequentially challenged with LY3792968 (10 nM), LY341495 (10 $\mu \mathrm{M})$ and LY3792968 + LY341495 or with 5-HT (1 $\mu \mathrm{M})$, M100907 (100 nM) and 5-HT + 
M100907. Right panels: cells were sequentially challenged with LY3792968, M100907 and LY3792968 + M100907 or with 5-HT, LY341495 and 5-HT + LY341495. Representative traces of N-type calcium channel currents obtained after 5-HT or LY3792968 challenges (in absence or presence of M100907 or LY341495) are illustrated. The histograms represent the means \pm SEM of $\mathrm{N}$-type calcium channel current inhibition measured for each condition in 10 cells originating from three independent cultures. Note that M100907 or LY341495 alone did not alter the N-type calcium channel current. One-way ANOVA (Post-hoc: Tukey's range test): $F(3,36)=89.9, p<0.0001 ; F(3,36)=78.18, p<0.0001$ in left and right panels, respectively. ${ }^{* * *} p<0.001$. 


\begin{tabular}{|c|c|c|c|c|c|c|c|c|c|c|}
\hline \multirow{3}{*}{ Modified sequence } & \multirow{3}{*}{ Species } & \multirow{3}{*}{ Start-end } & \multirow{3}{*}{$\begin{array}{c}\text { Experimental } \\
\mathrm{m} / \mathrm{z}(\mathrm{Th})\end{array}$} & \multirow{3}{*}{$\begin{array}{l}\text { Theoretical } \\
\text { mass (Da) }\end{array}$} & \multirow{3}{*}{$\begin{array}{c}\Delta \text { mass } \\
(\mathrm{ppm})\end{array}$} & \multirow{3}{*}{$\begin{array}{l}\text { Mascot } \\
\text { score }\end{array}$} & \multicolumn{4}{|c|}{ Phosphorylation site occupancy index } \\
\hline & & & & & & & \multicolumn{2}{|c|}{$\mathrm{mGlu}_{2}$} & \multicolumn{2}{|c|}{$\mathrm{mGlu}_{2}+5-\mathrm{HT}_{2 \mathrm{~A}}$} \\
\hline & & & & & & & Vehicle & LY37 & Vehicle & LY37 \\
\hline $\mathrm{REVVt}^{718} \mathrm{LR}+$ Phospho (ST) & Human & $714-720$ & 477,2515 & 951,4903 & $-5,40$ & 23 & $0,059 \pm 0.03$ & $0,057 \pm 0.03$ & $0,028 \pm 0.02$ & $0,042 \pm 0.02$ \\
\hline APTs ${ }^{833}$ RFGs $^{837}$ AAAR + 2 Phospho (ST) & Human & $830-841$ & 676,2813 & 1350,5482 & $-0,18$ & 31 & $0,222 \pm 0.10$ & $0,237 \pm 0.12$ & $0,228 \pm 0.10$ & $0,276 \pm 0.10$ \\
\hline $\mathrm{AS}^{843} \mathrm{~S}^{844} \mathrm{SLGQGSGSQFVPTVCNGR} \mathrm{+} \mathrm{Phospho} \mathrm{(ST)}$ & Human & $842-862$ & 1088,476 & 2174,9416 & $-1,93$ & 136 & $0,004 \pm 0.001$ & $0,010 \pm 0.001$ & $0,006 \pm 0.0007$ & $0,025 \pm 0.004^{\star * *}$ \\
\hline EVVDSTTSs $^{871} \mathrm{~L}+$ Phospho (ST) & Human & $863-872$ & 559,2383 & 1116,4588 & 2,9 & 53 & $0,052 \pm 0.02$ & $0,041 \pm 0.01$ & $0,052 \pm 0.01$ & $0,047 \pm 0.003$ \\
\hline $\mathrm{As}^{843} \mathrm{ANLGQGSGSQFVPTVCNGR} \mathrm{+} \mathrm{Phospho} \mathrm{(ST)}$ & Rat & $842-862$ & 1093,9878 & 2185,9576 & 1,57 & 60 & $0,040 \pm 0.01$ & $0,041 \pm 0.01$ & $0,032 \pm 0.01$ & $0,112 \pm 0.02^{*}$ \\
\hline
\end{tabular}

Table 1. List of phosphorylated peptides identified from purified $\mathbf{m G l u}_{2}$ receptors by nano-LC-MS/MS. HEK-293 cells transiently expressing human or rat Flag-tagged $\mathrm{mGlu}_{2}$ receptor, with or without HA-tagged 5- $\mathrm{HT}_{2 \mathrm{~A}}$ receptor, were exposed to either Vehicle or LY379268 (1 $\mu \mathrm{M}$, $15 \mathrm{~min}$ ). Solubilized receptors were immunoprecipitated with the anti-Flag M2 antibody, resolved by SDS-PAGE and digested in-gel with trypsin. Peptides were analyzed by nano-LC-MS/MS using multistage activation on the neutral loss of phosphoric acid. MS/MS spectra were manually interpreted. For each peptide, the position of modified residue(s), the position in the protein sequence, experimental mass/charge, theoretical mass, mass deviation, Mascot score, and relative abundance compared with the nonphosphorylated peptide (site occupancy index: maximal intensity observed in the phosphorylated peptide extracted ion chromatogram/sum of the maximal intensities observed in the phosphorylated and the non-phosphorylated peptide extracted ion chromatograms) are indicated. The data are the means of values calculated from three independent experiments performed on different sets of cultured cells. ${ }^{*} p<0.05,{ }^{* * *} p<0.001$ vs. corresponding vehicles. 
A

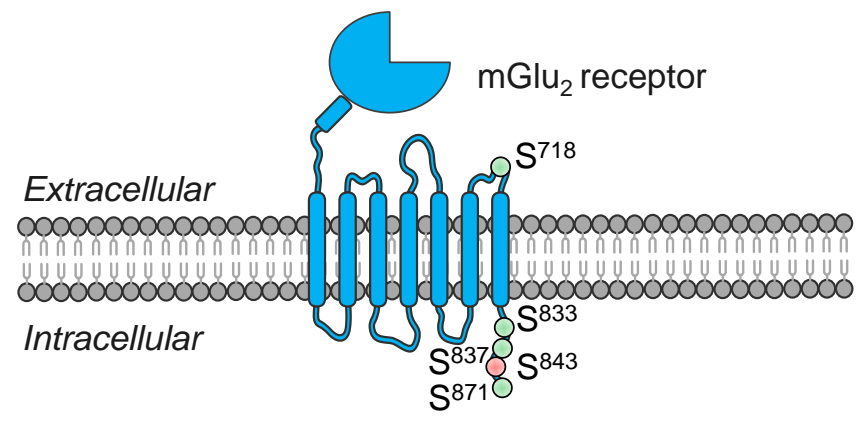

B

${ }^{836}$ GSAAARASSSLGQGSGSQFVPTVCNGR ${ }^{862}$ Human ${ }^{836}$ GSAAPRASANLGQGSGSQLVPTVCNGR ${ }^{862}$ Mice ${ }^{836}$ GSAAPRASANLGQGSGSQFVPTVCNGR ${ }^{862}$ Rat

D

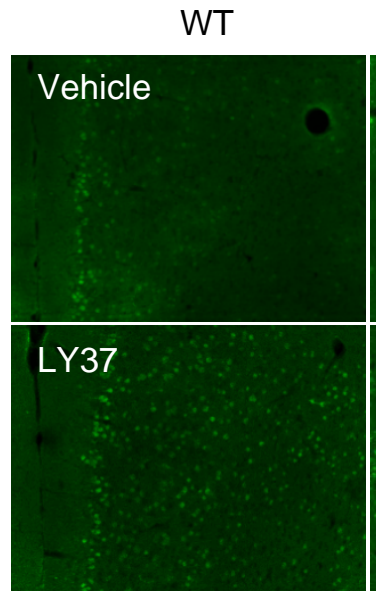

$5-\mathrm{HT}_{2 \mathrm{~A}}{ }^{-1-}$
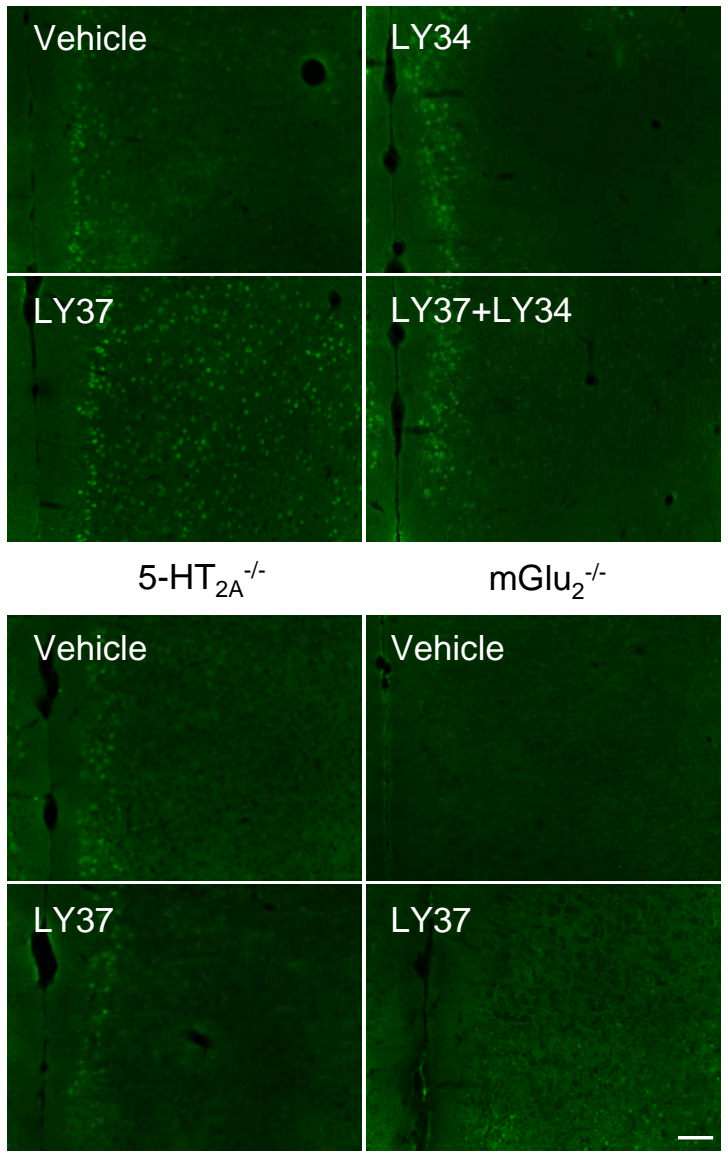

WT
C

Human $\mathrm{mGlu}_{2}$

Rat $\mathrm{mGlu}_{2}$
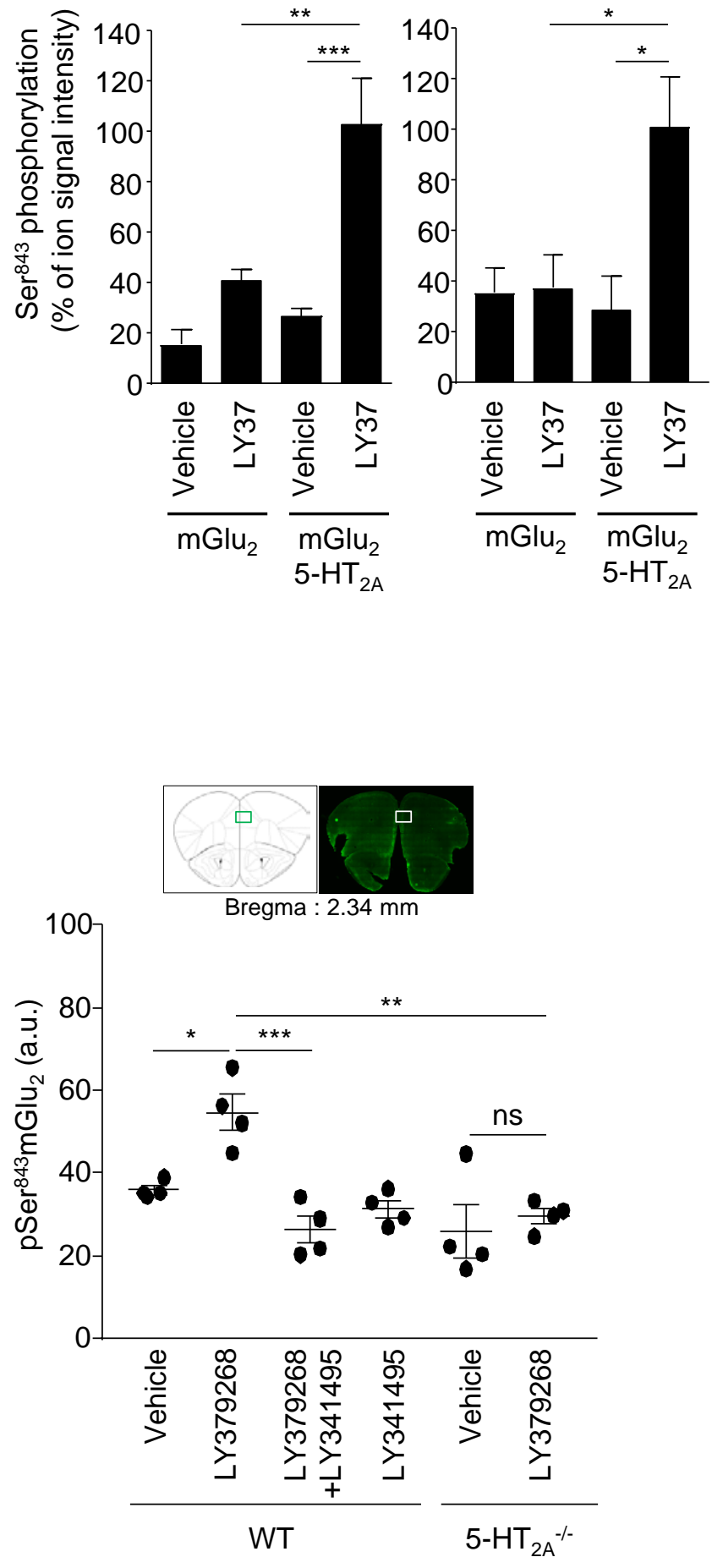


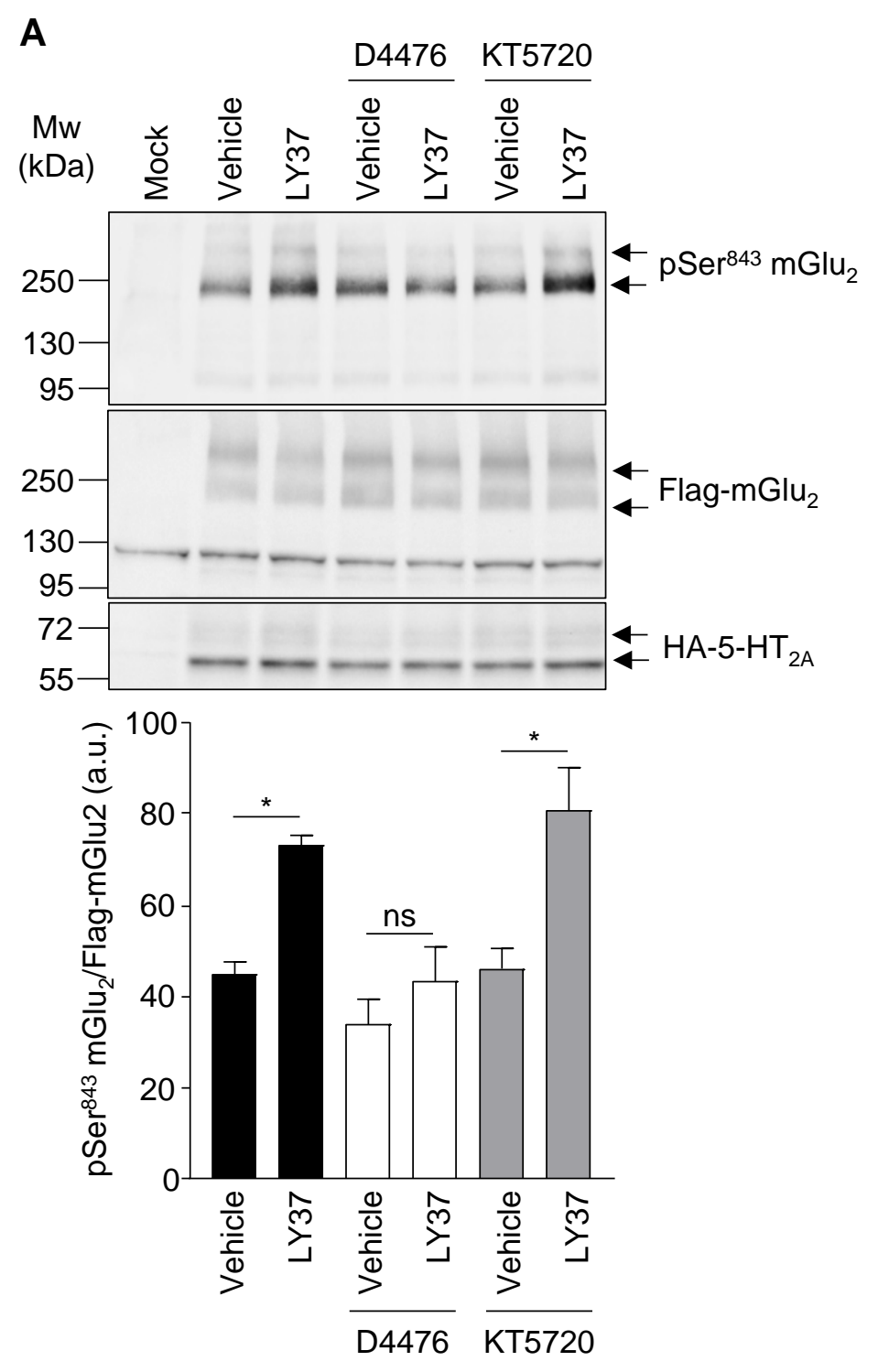

Control $\mathrm{CK} 1 \varepsilon$

SiRNA SiRNA
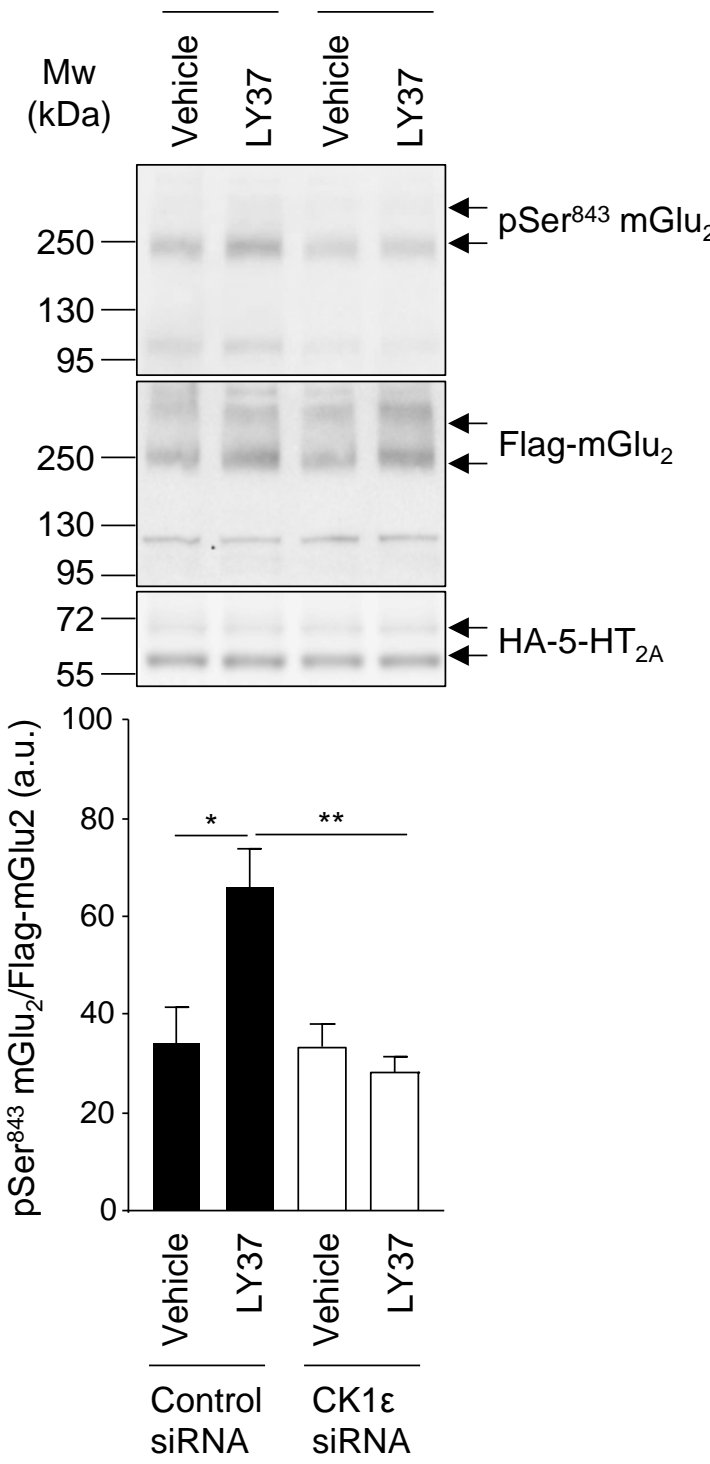

Figure 2 
A

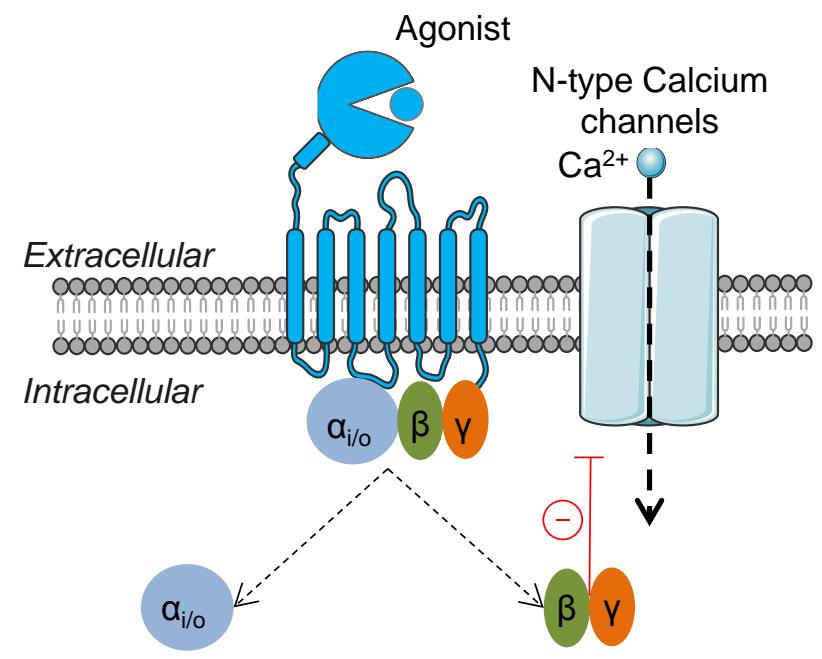

B
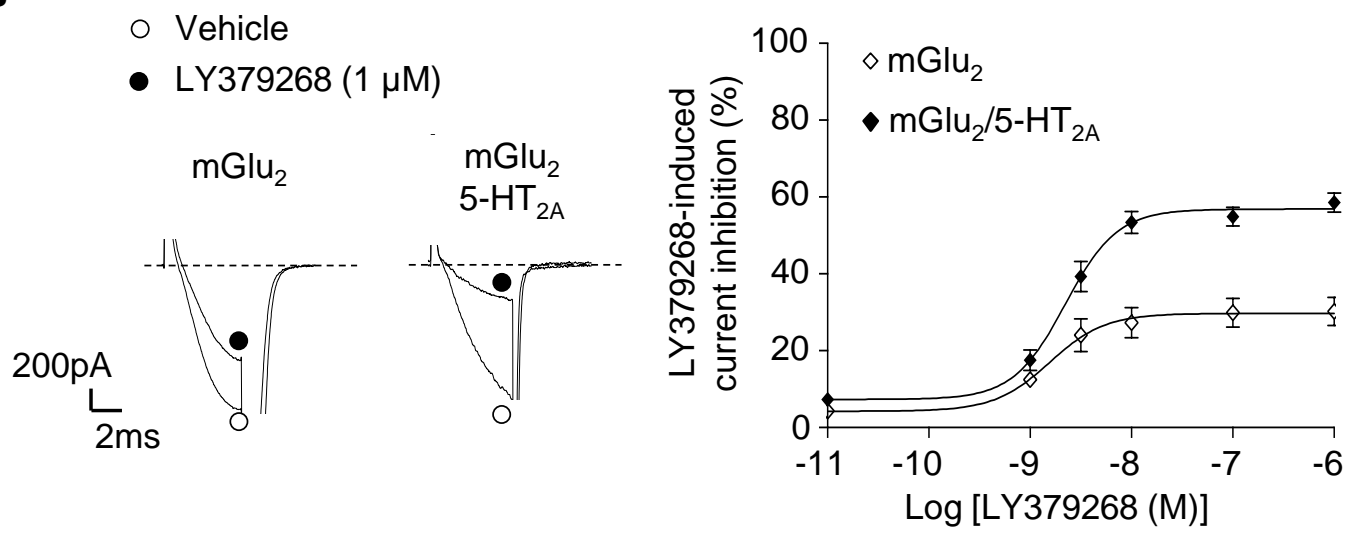

C
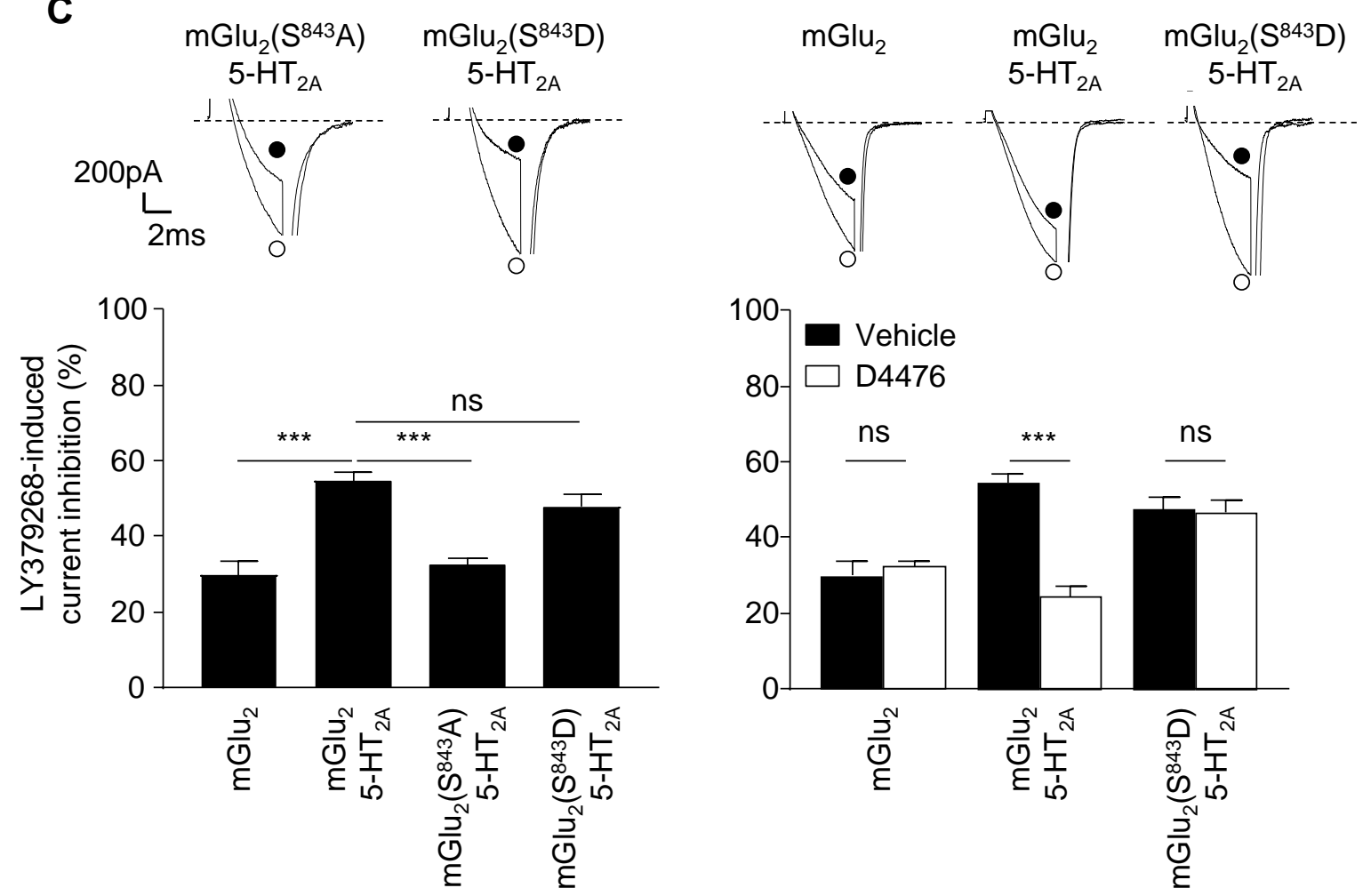

Figure 3 
A

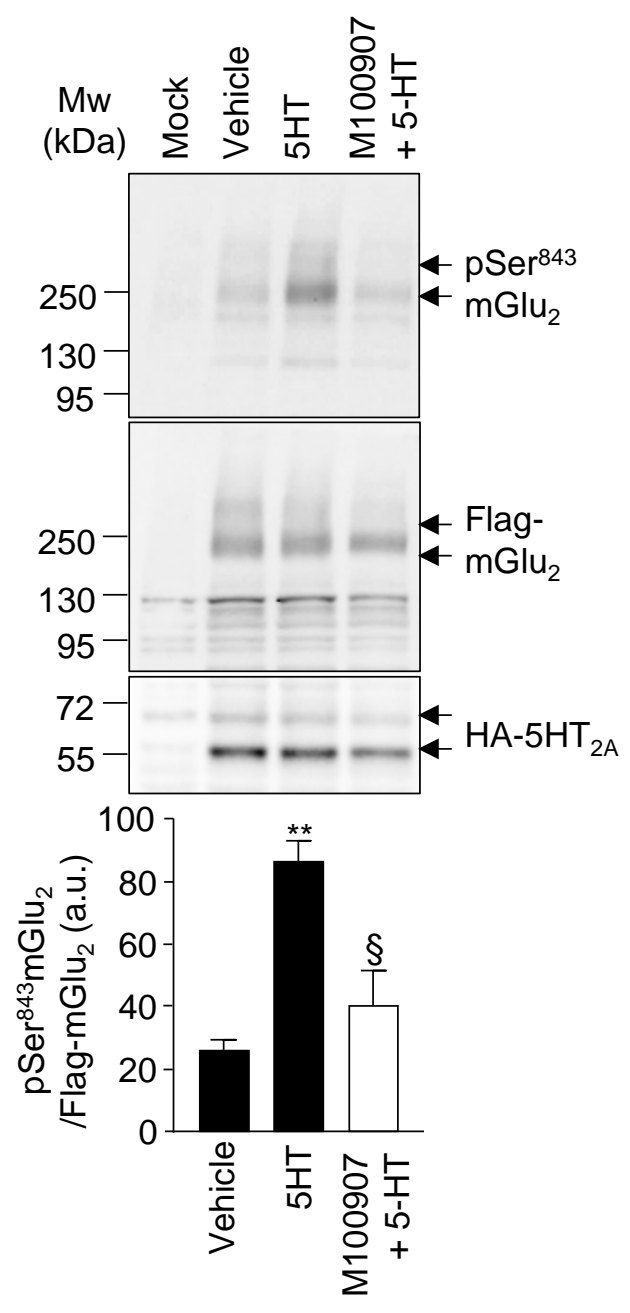

B

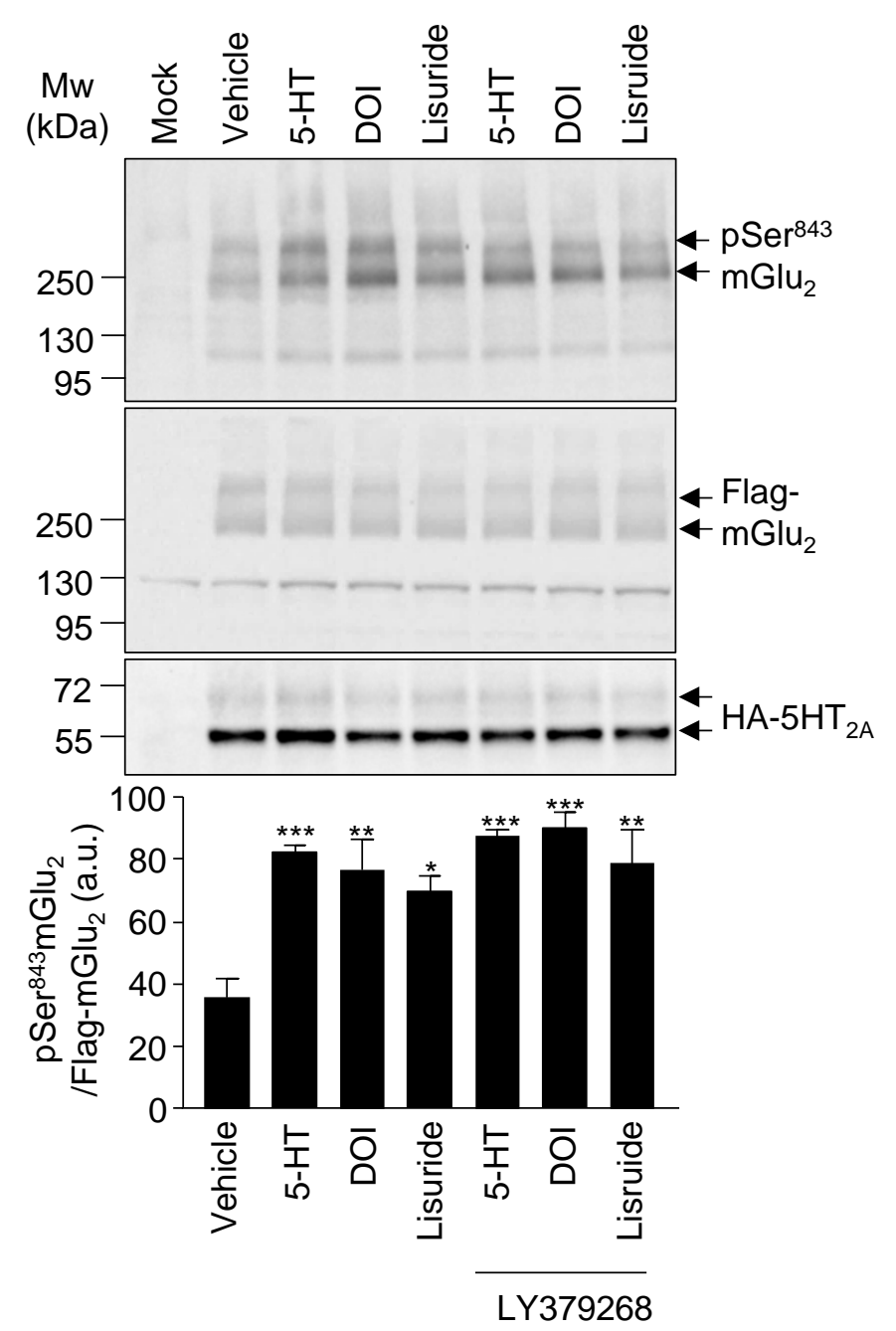

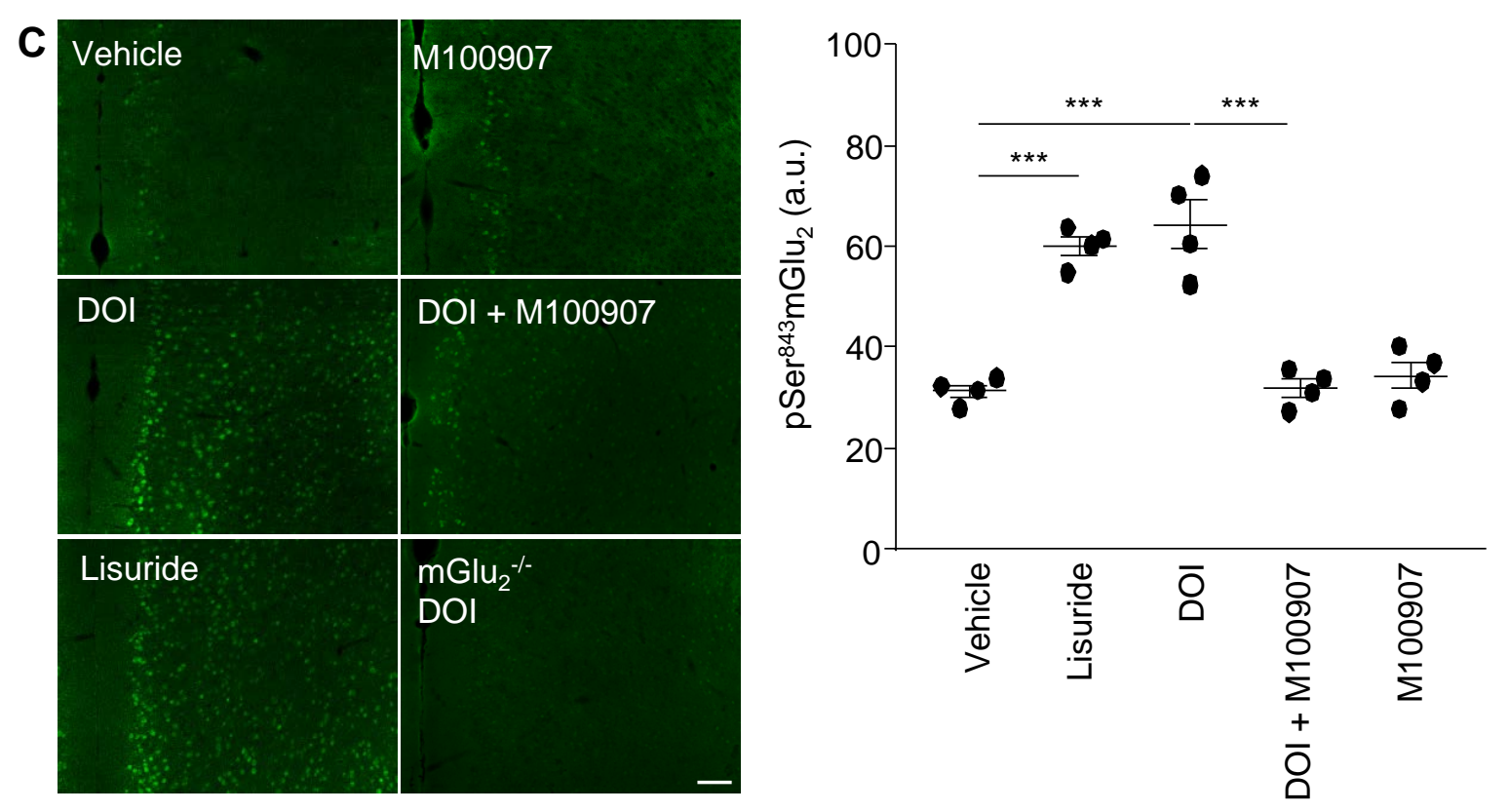

Figure 4 
A
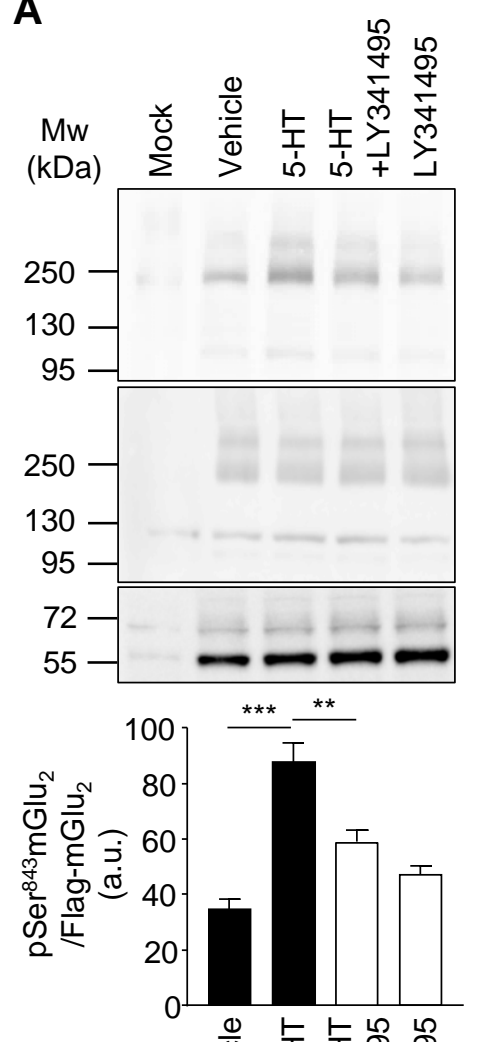

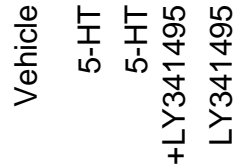

D

$$
5-\mathrm{HT}_{2 \mathrm{~A}} \quad \mathrm{mGlu}_{2}\left(\mathrm{~S}^{843} \mathrm{~A}\right) / 5-\mathrm{HT}_{2 \mathrm{~A}}
$$

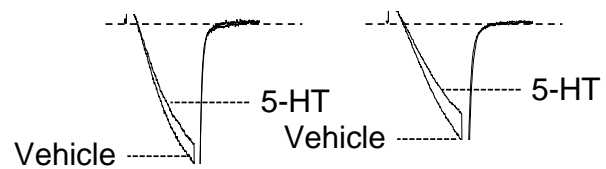

$$
\mathrm{mGlu}_{2} / 5-\mathrm{HT}_{2 \mathrm{~A}} \quad \mathrm{mGlu}_{2}\left(\mathrm{~S}^{843} \mathrm{D}\right) / 5-\mathrm{HT}_{2 \mathrm{~A}}
$$
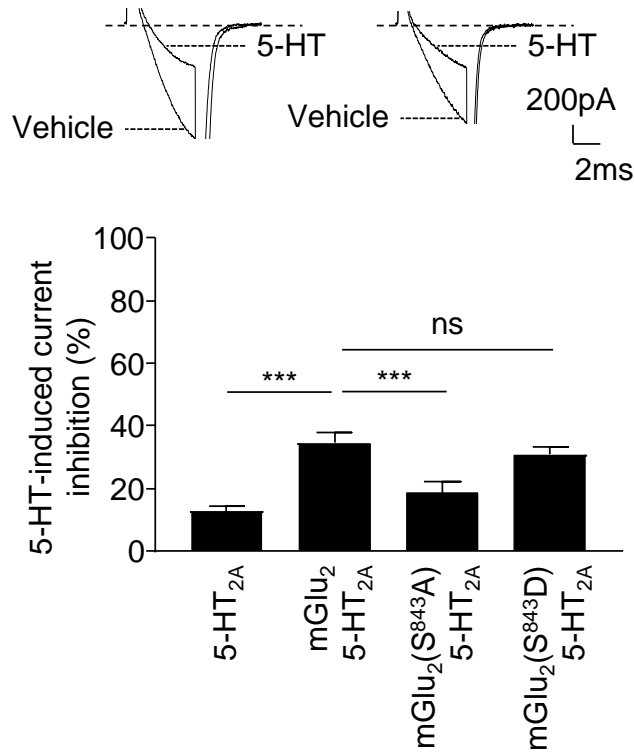

C

Prefrontal cortex

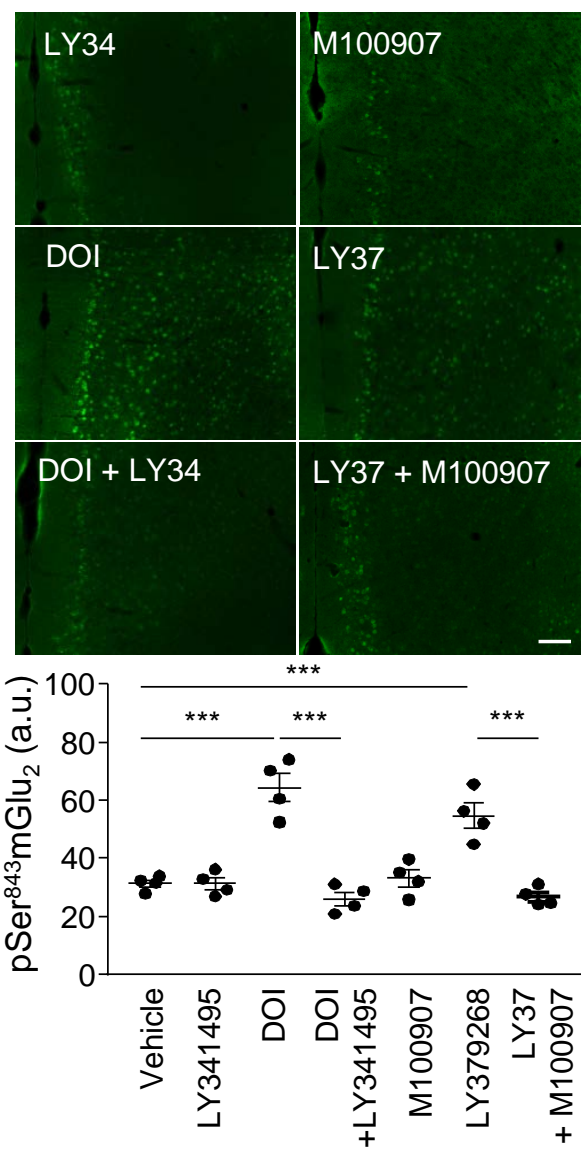

E $\mathrm{mGlu}_{2} / 5-\mathrm{HT}_{2 \mathrm{~A}}$

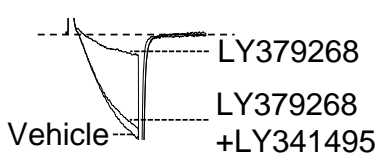

$\mathrm{mGlu}_{2} / 5-\mathrm{HT}_{2 \mathrm{~A}}$
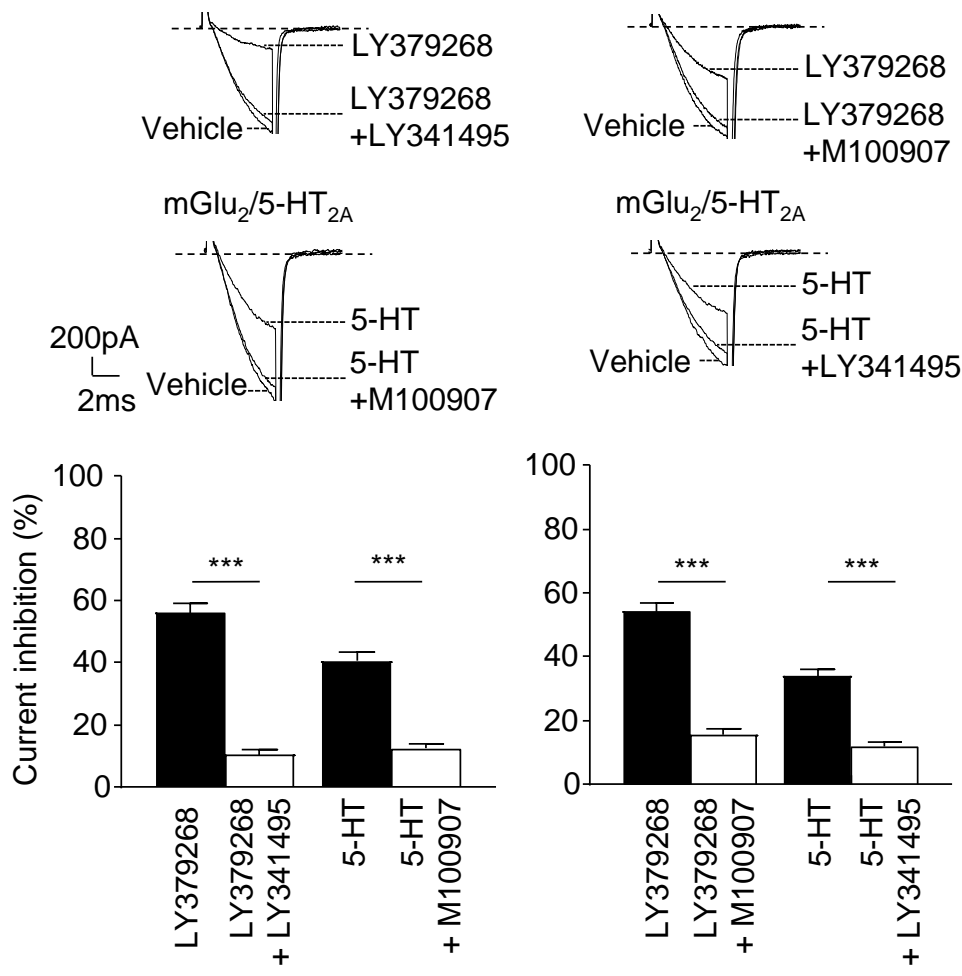
$\mathrm{mGlu}_{2}$ receptor coverage (Human) : $57 \%$ (exp pvalue cut off <0.05)

\begin{tabular}{|c|c|c|c|c|c|c|}
\hline 1 & MGSLLALLAL & LLLWGAVAEG & PAKKVLTLEG & \multicolumn{2}{|l|}{ DLVLGGLFPV } & HQKGGPAEDC \\
\hline 51 & GPVNEHRGIQ & RLEAMLFALD & RINRDPHLLP & \multicolumn{2}{|l|}{ GVRLGAHILD } & SCSKDTHALE \\
\hline 101 & QALDFVRASL & SRGADGSRHI & CPDGSYATHG & \multicolumn{2}{|l|}{ DAPTAITGVI } & GGSYSDVSIQ \\
\hline 151 & VANLLRLFQI & PQISYASTSA & KLSDKSRYDY & \multicolumn{2}{|l|}{ FARTVPPDFF } & QAKAMAEILR \\
\hline 201 & FFNWTYVSTV & ASEGDYGETG & IEAFELEARA & \multicolumn{2}{|l|}{ RNICVATSEK } & VGRAMSRAAF \\
\hline 251 & EGVVRALLQK & PSARVAVLFT & RSEDARELLA & \multicolumn{2}{|l|}{ ASQRLNASFT } & WVASDGWGAL \\
\hline 301 & ESVVAGSEGA & AEGAITIELA & SYPISDFASY & \multicolumn{2}{|l|}{ FQSLDPWNNS } & RNPWFREFWE \\
\hline 351 & QRFRCSFRQR & DCAAHSLRAV & PFEQESKIMF & \multicolumn{2}{|l|}{ VVNAVYAMAH } & ALHNMHRALC \\
\hline 401 & PNTTRLCDAM & RPVNGRRLYK & DFVLNVKFDA & \multicolumn{2}{|l|}{ PFRPADTHNE } & VRFDRFGDGI \\
\hline 451 & GRYNIFTYLR & AGSGRYRYQK & VGYWAEGLTL & \multicolumn{2}{|l|}{ DTSLIPWASP } & SAGPLPASRC \\
\hline 501 & SEPCLQNEVK & SVQPGEVCCW & LCIPCQPYEY & \multicolumn{2}{|l|}{ RLDEFTCADC } & GLGYWPNASL \\
\hline 551 & TGCFELPQEY & IRWGDAWAVG & PVTIACLGAL & \multicolumn{2}{|l|}{ ATLFVLGVFV } & RHNATPVVKA \\
\hline 601 & SGRELCYILL & GGVFLCYCMT & FIFIAKPSTA & \multicolumn{2}{|l|}{ VCTLRRLGLG } & TAFSVCYSAL \\
\hline 651 & LTKTNRIARI & FGGAREGAQR & PRFISPASQV & \multicolumn{2}{|l|}{ AICLALISGQ } & LLIWAWLVV \\
\hline 701 & EAPGTGKETA & PERREVV t ${ }^{718}$ LR & CNHRDASMLG & \multicolumn{2}{|l|}{ SLAYNVLLIA } & LCTLYAFKTR \\
\hline 751 & KCPENFNEAK & FIGFTMYTTC & IIWLAFLPIF & \multicolumn{2}{|c|}{ YVTSSDYRVQ } & TTTMCVSVSL \\
\hline 801 & SGSWLGCLF & APKLHIILFQ & PQKNVVSHRA & \multicolumn{2}{|c|}{ PTs $\mathbf{s}^{833}$ RFG $^{837}$ AAA } & RAS $^{843} \mathrm{~S}^{844}$ SLGQGS \\
\hline \multirow[t]{2}{*}{851} & GSQFVPTVCN & GREVVDSTTS & $S^{871} \mathbf{L}$ & & & \\
\hline & \multicolumn{6}{|c|}{ mGlu $_{2}$ receptor coverage (Rat) : 40\% (exp pvalue cut off <0.05) } \\
\hline 1 & MESLLGFLAL & LLLWGAVAEG & PAKKVLTLEG & DLVLGGLFPV & \multicolumn{2}{|c|}{ HQKGGPAEEC } \\
\hline 51 & GPVNEHRGIQ & RLEAMLFALD & RINRDPHLLP & GVRLGAHILD & \multicolumn{2}{|c|}{ SCSKDTHALE } \\
\hline 101 & QALDFVRASL & SRGADGSRHI & CPDGSYATHS & DAPTAVTGVI & \multicolumn{2}{|c|}{ GGSYSDVSIQ } \\
\hline 151 & VANLLRLFQI & PQISYASTSA & KLSDKSRYDY & FARTVPPDFF & \multicolumn{2}{|c|}{ QAKAMAEILR } \\
\hline 201 & FFNWTYVSTV & ASEGDYGETG & IEAFELEARA & RNICVATSEK & \multicolumn{2}{|c|}{ VGRAMSRAAF } \\
\hline 251 & EGVVRALLQK & PSARVAVLFT & RSEDARELLA & ATQRLNASFT & \multicolumn{2}{|c|}{ WVASDGWGAL } \\
\hline 301 & ESVVAGSERA & AEGAITIELA & SYPISDFASY & FQSLDPWNNS & \multicolumn{2}{|c|}{ RNPWFREFWE } \\
\hline 351 & ERFHCSFRQR & DCAAHSLRAV & PFEQESKIMF & VVNAVYAMAH & \multicolumn{2}{|c|}{ ALHNMHRALC } \\
\hline 401 & PNTTHLCDAM & RPVNGRRLYK & DFVLNVKFDA & PFRPADTDDE & VRF & DRFGDGI \\
\hline 451 & GRYNIFTYLR & AGSGRYRYQK & VGYWAEGLTL & DTSFIPWASP & SAC & PLPASRC \\
\hline 501 & SEPCLQNEVK & SVQPGEVCCW & LCIPCQPYEY & RLDEFTCADC & GLC & YYWPNASL \\
\hline 551 & TGCFELPQEY & IRWGDAWAVG & PVTIACLGAL & ATLFVLGVFV & RHI & NATPWVKA \\
\hline 601 & SGRELCYILL & GGVFLCYCMT & FVFIAKPSTA & VCTLRRLGLG & TAF & SVCYSAL \\
\hline 651 & LTKTNRIARI & FGGAREGAQR & PRFISPASQV & AICLALISGQ & LLI & /AAWLVV \\
\hline 701 & EAPGTGKETA & PERREVVTLR & CNHRDASMLG & SLAYNVLLIA & LCT & LYAFKTR \\
\hline 751 & KCPENFNEAK & FIGFTMYTTC & IIWLAFLPIF & YVTSSDYRVQ & TTT & MCVSVSL \\
\hline 801 & SGSWLGCLF & APKLHIILFQ & PQKNVVSHRA & PTSRFGSAAP & RA & ${ }^{843}$ ANLGQGS \\
\hline 851 & GSQFVPTVCN & GREVVDSTTS & $S^{871} \mathbf{L}$ & & & \\
\hline
\end{tabular}

\section{Supplementary Figure 1 . Sequence coverage of human and rat $\mathrm{mGlu}_{2}$ receptors}

obtained by LC-MS/MS. The sequence covered by LC-MS/MS analysis is highlighted in red. Identified phosphorylated residues in human $m$ Glu 2 receptor $\left(\operatorname{Thr}^{718}, \operatorname{Ser}^{833}, \operatorname{Ser}^{837}\right.$, $\left.\operatorname{Ser}^{843 / 844}, \operatorname{Ser}^{871}\right)$ and rat $\mathrm{mGlu}_{2}$ receptor $\left(\operatorname{Ser}^{843}, \mathrm{Ser}^{871}\right)$ and their positions are highlighted in blue. 

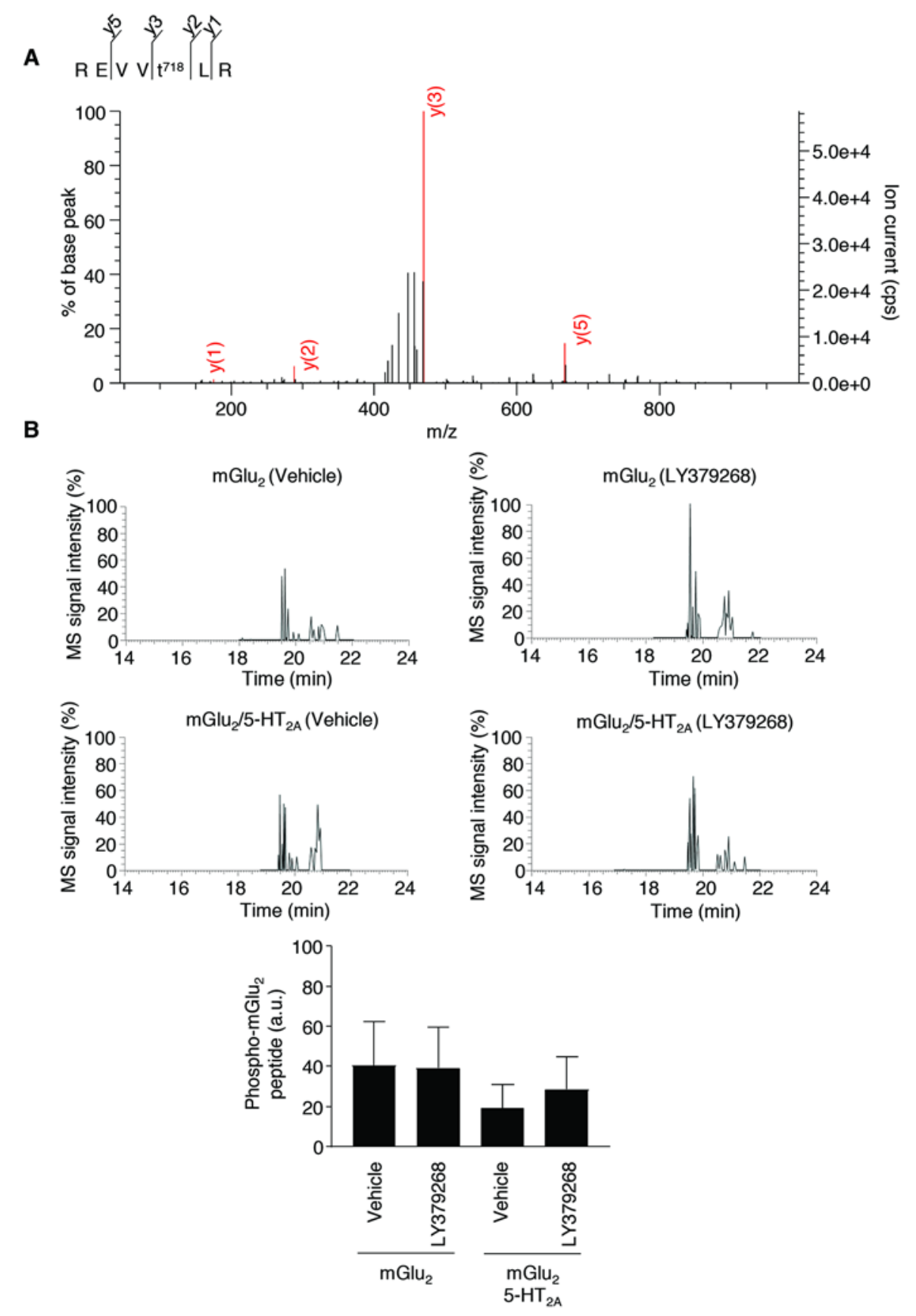

Supplementary Figure 2. Identification and quantification of the REVVt ${ }^{718} \mathrm{LR}$ phosphorylated peptide by LC-MS. A, The MS/MS spectrum that yielded the highest Mascot score, matched $b$ and $y$ ions, peptide sequence and position of the phosphorylated residue in the full-length human $\mathrm{mGlu}_{2}$ receptor are illustrated. $\mathbf{B}$, Representative extracted ion chromatograms of this peptide in cells expressing $\mathrm{mGlu}_{2}$ receptor alone or in combination with 5- $\mathrm{HT}_{2 \mathrm{~A}}$ receptor, and exposed to either vehicle or LY379268 (1 $\left.\mu \mathrm{M}\right)$ for 15 $\min$. The histogram represents the means \pm SEM of ion signal intensities of $R E V V t^{718} L R$ phosphorylated peptide obtained in three independent experiments performed on independent cultures. One-way ANOVA (Post-hoc: Tukey's range test): $F(3,12)=0.3072$, $\mathrm{p}=0.8197$. 


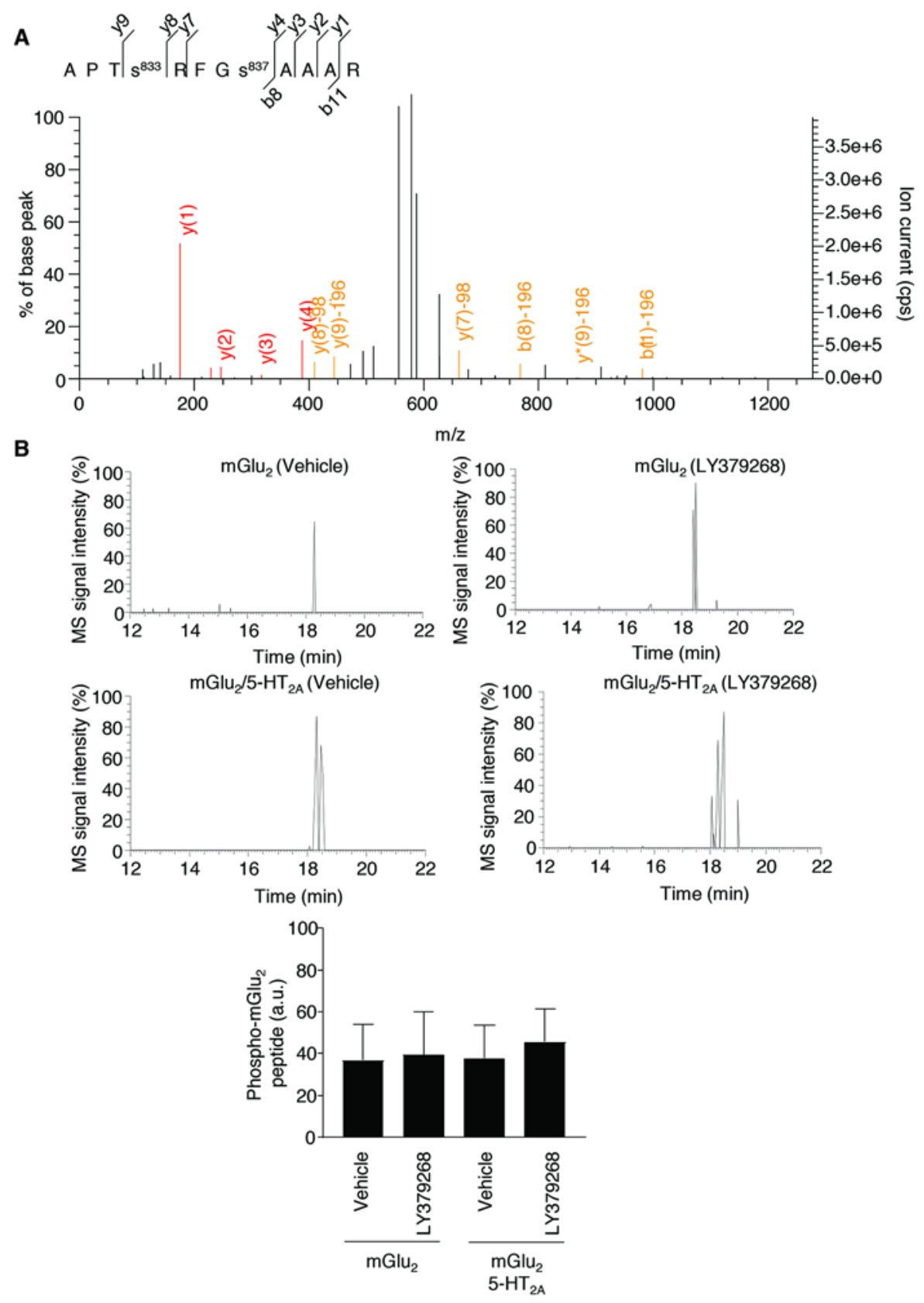

Supplementary Figure 3. Identification and quantification of the APTs ${ }^{833}$ RFG $^{837}$ AAAR phosphorylated peptide by LC-MS. A, The MS/MS spectrum that yielded the highest Mascot score, matched $\mathrm{b}$ and $\mathrm{y}$ ions, peptide sequence and position of the phosphorylated residue in the full-length human mGlu $_{2}$ receptor are illustrated. $\mathbf{B}$, Representative extracted ion chromatograms of this peptide in cells expressing $\mathrm{mGlu}_{2}$ receptor alone or in combination with 5- $\mathrm{HT}_{2 \mathrm{~A}}$ receptor, and exposed to either vehicle or $\mathrm{LY} 379268(1 \mu \mathrm{M})$ for 15 min. The histogram represents the means \pm SEM of ion signal intensities of APTs ${ }^{833}{ }^{2} F G s^{837}$ AAAR phosphorylated peptide obtained in three independent experiments performed on independent cultures. One-way ANOVA (Post-hoc: Tukey's range test): $F(3,12)=0.05346, p=0.9829$. 

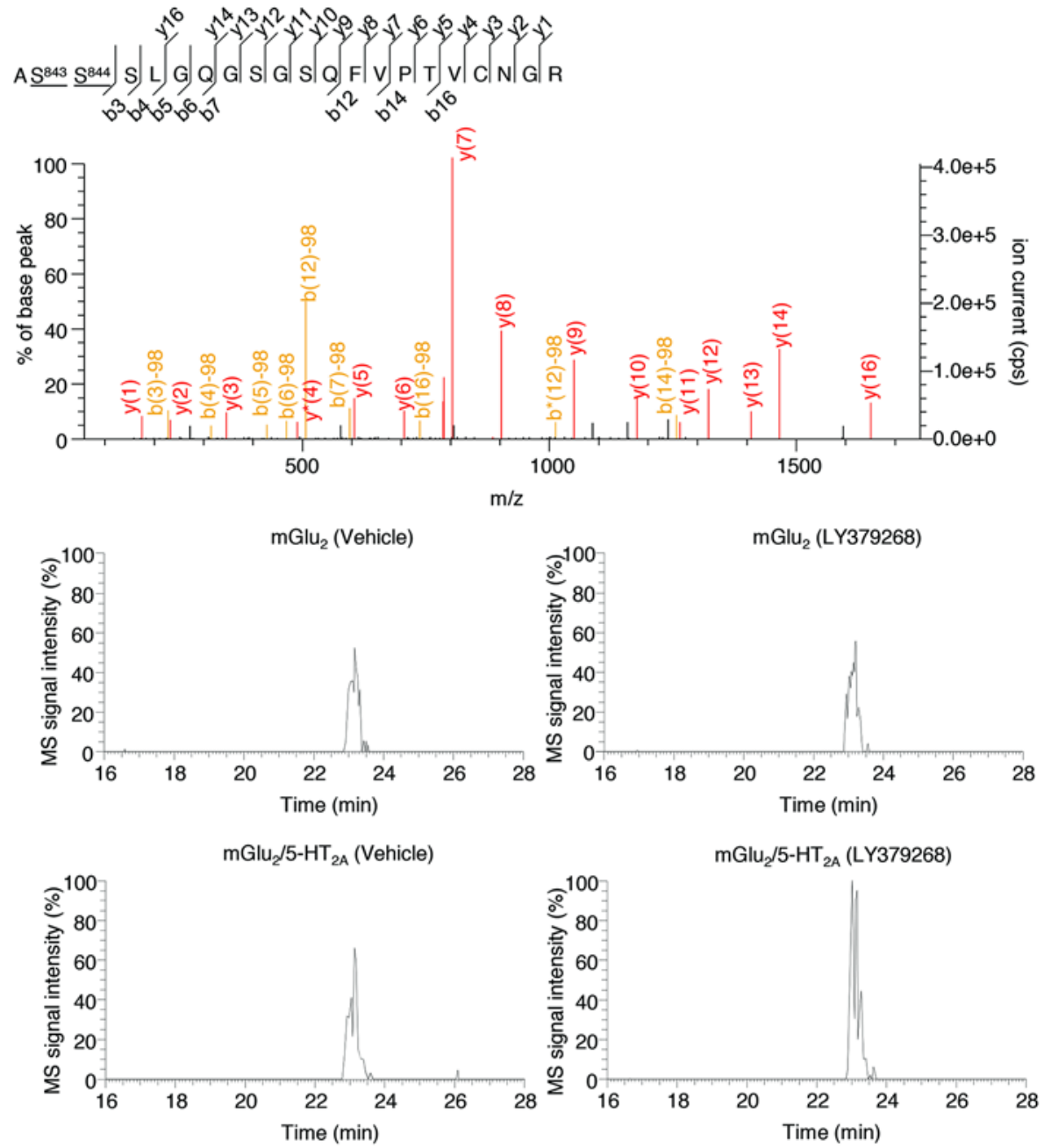

Supplementary Figure 4. Identification and quantification of the $\mathrm{AS}^{843} \mathrm{~S}^{844}$ SLGQGSGSQFVPTVCNGR phosphorylated peptide by LC-MS. The MS/MS spectrum that yielded the highest Mascot score, matched b and y ions, peptide sequence and position of the phosphorylated residue in the full-length human $\mathrm{mGlu}_{2}$ receptor are illustrated (top panel). The bottom panels show representative extracted ion chromatograms of the peptide in cells expressing $\mathrm{mGlu}_{2}$ receptor alone or in combination with $5-\mathrm{HT}_{2 \mathrm{~A}}$ receptor, and exposed to either vehicle or LY379268 (1 $\mu \mathrm{M})$ for $15 \mathrm{~min}$. 


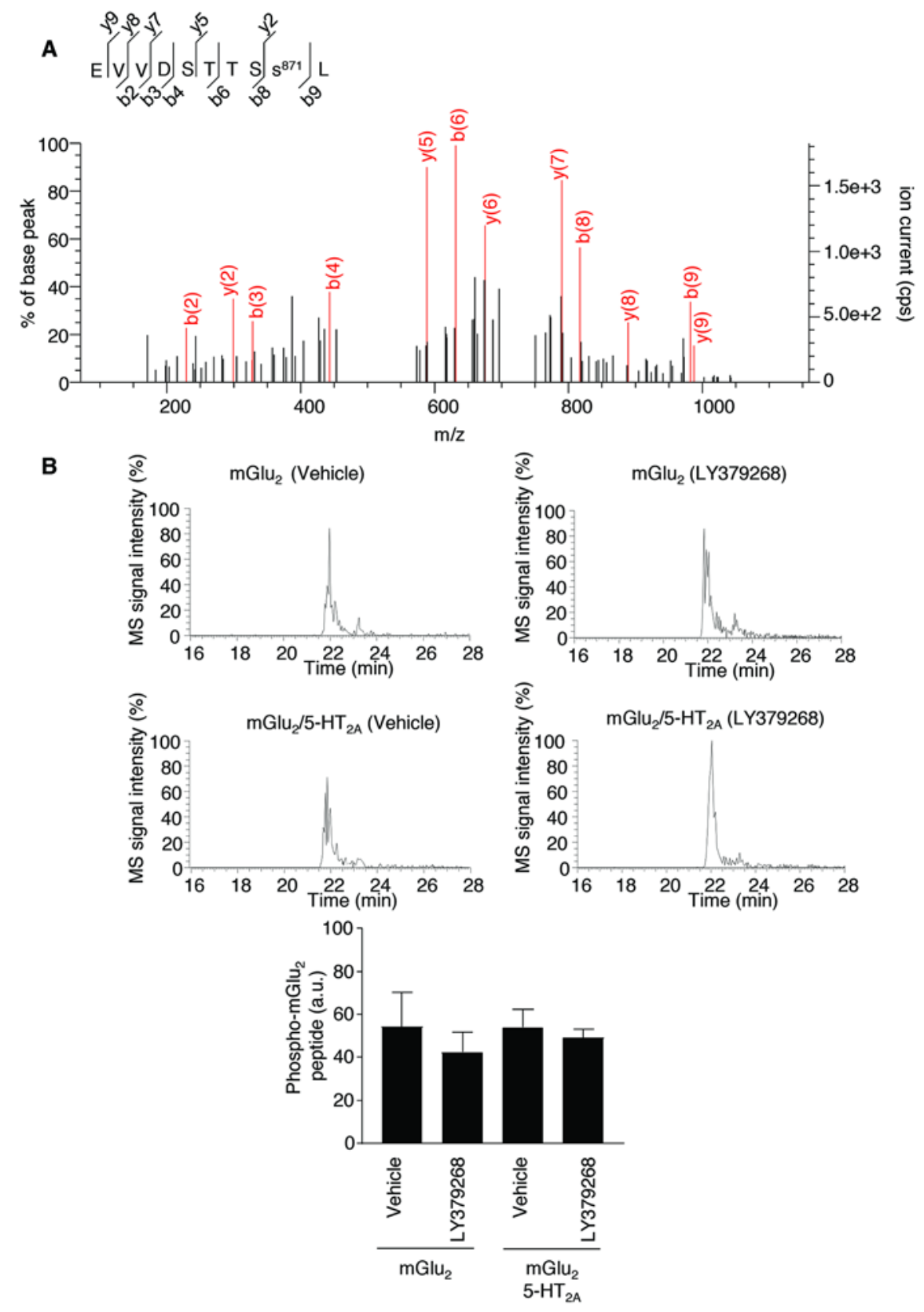

Supplementary Figure 5. Identification and quantification of the EVVDSTTSs ${ }^{871} L$ phosphorylated peptide by LC-MS. A, The MS/MS spectrum that yielded the highest Mascot score, matched $\mathrm{b}$ and $\mathrm{y}$ ions, peptide sequence and position of the phosphorylated residue in the full-length human $\mathrm{mGlu}_{2}$ receptor are illustrated. $\mathbf{B}$, Representative extracted ion chromatograms of this peptide in cells expressing $\mathrm{mGlu}_{2}$ receptor alone or in combination with 5- $\mathrm{HT}_{2 \mathrm{~A}}$ receptor, and exposed to either vehicle or LY379268 (1 $\left.\mu \mathrm{M}\right)$ for 15 $\min$. The histogram represents the means \pm SEM of ion signal intensities of EVVDSTTSs ${ }^{871} L$ phosphorylated peptide obtained in three independent experiments performed on independent cultures. One-way ANOVA (Post-hoc: Tukey's range test): $F(3,12)=0.2874$, $\mathrm{p}=0.8337$. 
A $\mathrm{mGlu}_{2}$ receptor coverage (Human) : $31 \%$ (exp pvalue cut off $<0.05$ )

\begin{tabular}{|c|c|c|c|c|c|}
\hline 1 & MGSLLALLAL & LLLWGAVAEG & PAKKVLTLEG & DLVLGGLFPV & HQKGGPAEDC \\
\hline 51 & GPVNEHRGIQ & RLEAMLFALD & RINRDPHLLP & GVRLGAHILD & SCSKDTHALE \\
\hline 101 & QALDFVRASL & SRGADGSRHI & CPDGSYATHG & DAPTAITGVI & GGSYSDVSIQ \\
\hline 151 & VANLLRLFQI & PQISYASTSA & KLSDKSRYDY & FARTVPPDFF & QAKAMAEILR \\
\hline 201 & FFNWTYVSTV & ASEGDYGETG & IEAFELEARA & RNICVATSEK & VGRAMSRAAF \\
\hline 251 & EGVVRALLQK & PSARVAVLFT & RSEDARELLA & ASQRLNASFT & WVASDGWGAL \\
\hline 301 & ESVVAGSEGA & AEGAITIELA & SYPISDFASY & FQSLDPWNNS & RNPWFREFWE \\
\hline 351 & QRFRCSFRQR & DCAAHSLRAV & PFEQESKIMF & VVNAVYAMAH & ALHNMHRALC \\
\hline 401 & PNTTRLCDAM & RPVNGRRLYK & DFVLNVKFDA & PFRPADTHNE & VRFDRFGDGI \\
\hline 451 & GRYNIFTYLR & AGSGRYRYQK & VGYWAEGLTL & DTSLIPWASP & SAGPLPASRC \\
\hline 501 & SEPCLQNEVK & SVQPGEVCCW & LCIPCQPYEY & RLDEFTCADC & GLGYWPNASL \\
\hline 551 & TGCFELPQEY & IRWGDAWAVG & PVTIACLGAL & ATLFVLGVFV & RHNATPVWKA \\
\hline 601 & SGRELCYILL & GGVFLCYCMT & FIFIAKPSTA & VCTLRRLGLG & TAFSVCYSAL \\
\hline 651 & LTKTNRIARI & FGGAREGAQR & PRFISPASQV & AICLALISGQ & LLIWVAWLW \\
\hline 701 & EAPGTGKETA & PERREWTLR & CNHRDASMLG & SLAYNVLLIA & LCTLYAFKTR \\
\hline 751 & KCPENFNEAK & FIGFTMYTTC & IIWLAFLPIF & YVTSSDYRVQ & TTTMCVSVSL \\
\hline 801 & SGSWLGCLF & APKLHIILFQ & PQKNVVSHRA & PTSRFGSAAA & RA $S^{843} S^{844} S^{845} \mathbf{L}$ \\
\hline 851 & GSQFVPTVCN & GREVVDSTTS & $S^{871} \mathbf{L}$ & & \\
\hline
\end{tabular}

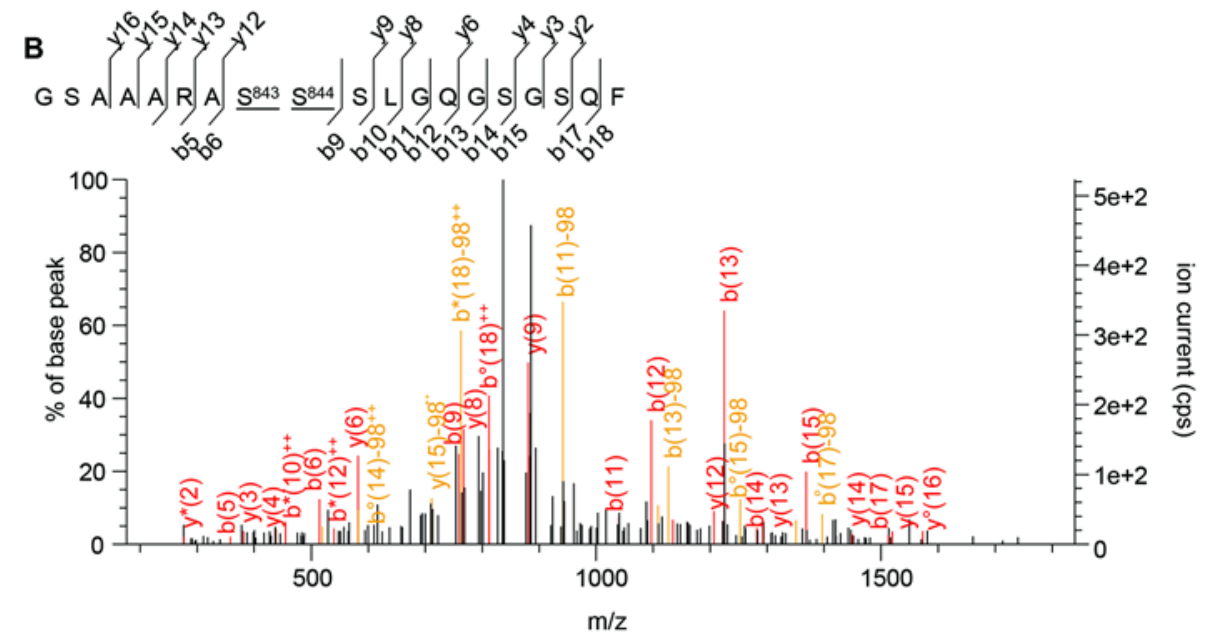

\section{Supplementary Figure 6. LC-MS analysis of human $\mathrm{mGlu}_{2}$ receptor digested with}

chymotrypsin. A, The sequence covered by LC-MS/MS analysis after in-gel digestion of human $\mathrm{mGlu}_{2}$ receptor with chymotrypsin is highlighted in red. Identified phosphorylated residues and their positions in the protein sequence are highlighted in blue. $\mathbf{B}$, The MS/MS spectrum of the GSAAARAS ${ }^{843} \mathrm{~S}^{844}$ SLGQGSGSQF phosphorylated peptide that yielded the highest Mascot score, matched $\mathrm{b}$ and $\mathrm{y}$ ions, peptide sequence and position of the possible phosphorylated residues in the full-length receptor are underlined. 

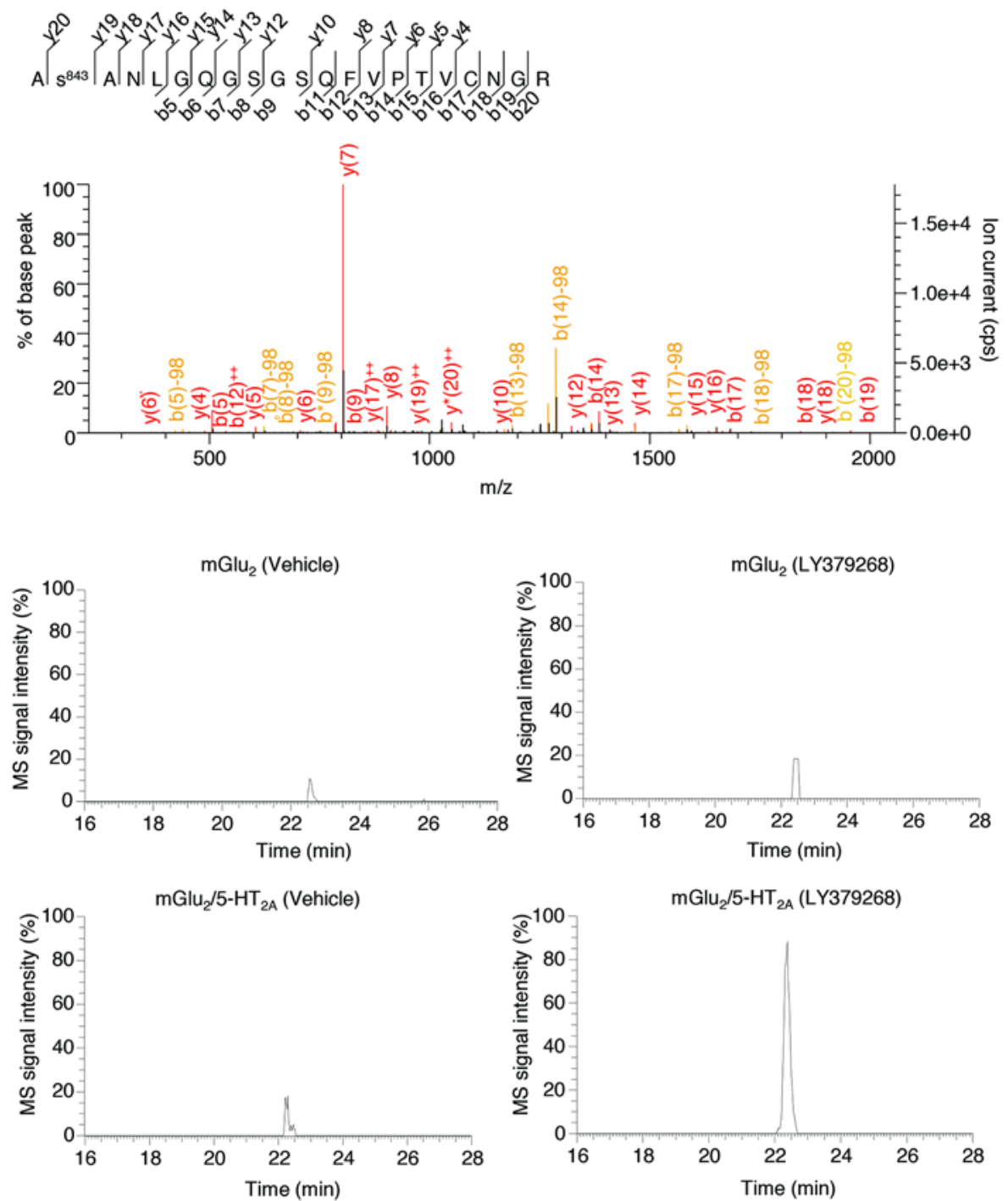

Supplementary Figure 7. Identification and quantification of the $\mathrm{As}^{843}$ ANLGQGSGSQFVPTVCNGR phosphorylated peptide by LC-MS. The MS/MS spectrum that yielded the highest Mascot score, matched $b$ and $y$ ions, peptide sequence and position of the phosphorylated residue in the full-length rat $\mathrm{mGlu}_{2}$ receptor are illustrated (top panel). The bottom panels show representative extracted ion chromatograms of the $A s^{843}$ ANLGQGSGSQFVPTVCNGR peptide in cells expressing $\mathrm{mGlu}_{2}$ receptor alone or in combination with 5- $\mathrm{HT}_{2 \mathrm{~A}}$ receptor and treated with either vehicle or LY379268 (1 $\left.\mu \mathrm{M}\right)$ for 15 $\min$. 


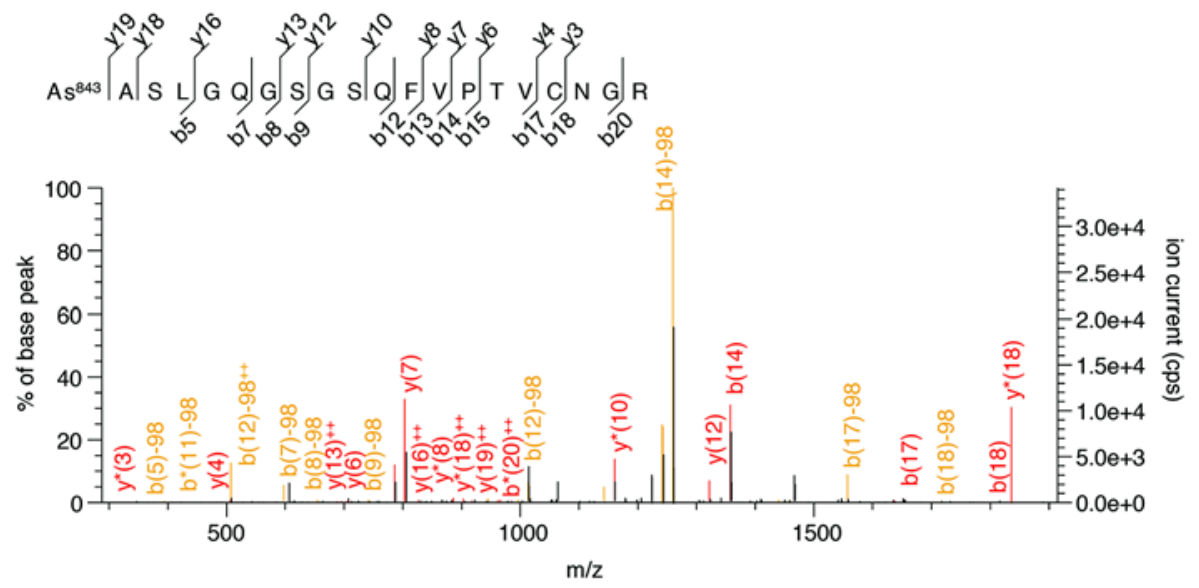

Supplementary Figure 8. Identification of the $\mathrm{As}^{843}$ ASLGQGSGSQFVPTVCNGR phosphorylated peptide in $\mathrm{S}^{844} \mathbf{A} \mathbf{m G l u}_{2}$ receptor. The MS/MS spectrum that yielded the highest Mascot score, matched $\mathrm{b}$ and $\mathrm{y}$ ions, peptide sequence and position of the phosphorylated residue in the full-length human $\mathrm{S}^{844} \mathrm{~A} \mathrm{mGlu}_{2}$ receptor are illustrated. 


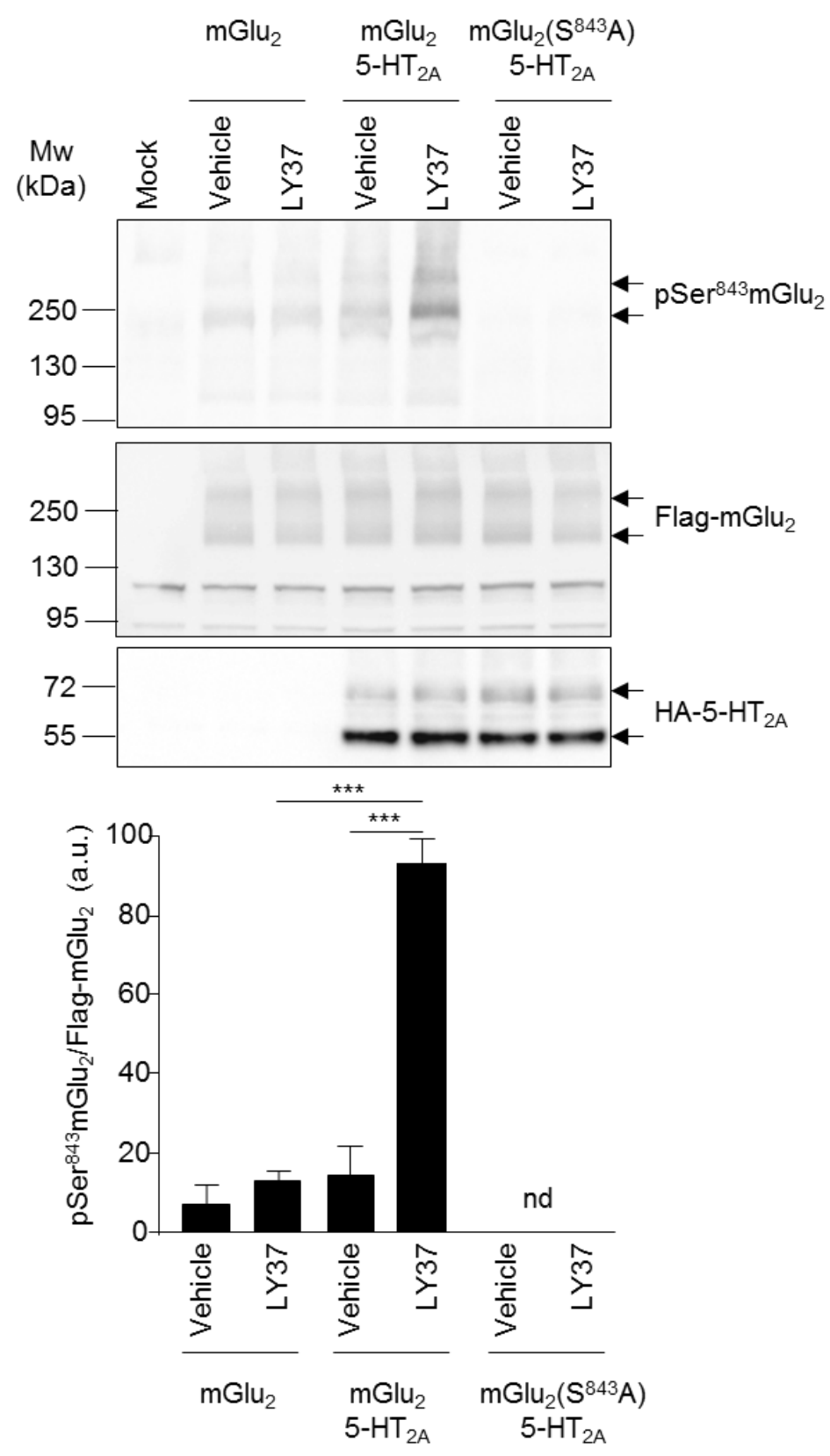

Supplementary Figure 9. Validation of the anti-phospho-Ser ${ }^{843} \mathbf{m G l u}_{2}$ receptor antibody by Western blotting. HEK-293 cells transiently expressing rat Flag-tagged $\mathrm{mGlu}_{2}$ receptor alone or in combination with $\mathrm{HA}$-tagged $5-\mathrm{HT}_{2 \mathrm{~A}}$ receptor or co-expressing rat Flagtagged $\mathrm{S}^{843} \mathrm{~A} \mathrm{mGlu}_{2}$ receptor and $\mathrm{HA}$-tagged $5-\mathrm{HT}_{2 \mathrm{~A}}$ receptor were exposed to vehicle or LY379268 (LY37, $1 \mu \mathrm{M})$ for $15 \mathrm{~min}$. mGlu $_{2}$ receptor phosphorylation was analyzed by sequential immunoblotting with the antibody raised against the CAAPRAsANLGQG peptide and the anti-Flag antibody. Representative blots of three independent experiments performed on different sets of cultured cells are illustrated. The generated antibody provided an immunoreactive signal in Western blots from cells expressing Flag-tagged $\mathrm{mGlu}_{2}$ receptors at a molecular weight corresponding to the signal obtained with the anti-Flag antibody. The histograms show the means \pm SEM of the anti-phospho-Ser ${ }^{843} \mathrm{mGlu}_{2}$ receptor immunoreactive signal relative to Flag immunoreactive signal (expressed in arbitrary units, a.u.) obtained in the three experiments. One-way ANOVA (Post-hoc: Tukey's range test): $F(5,12)=58.02, p<0.0001 .{ }^{* \star *} p<0.001$. nd: non-detectable. 

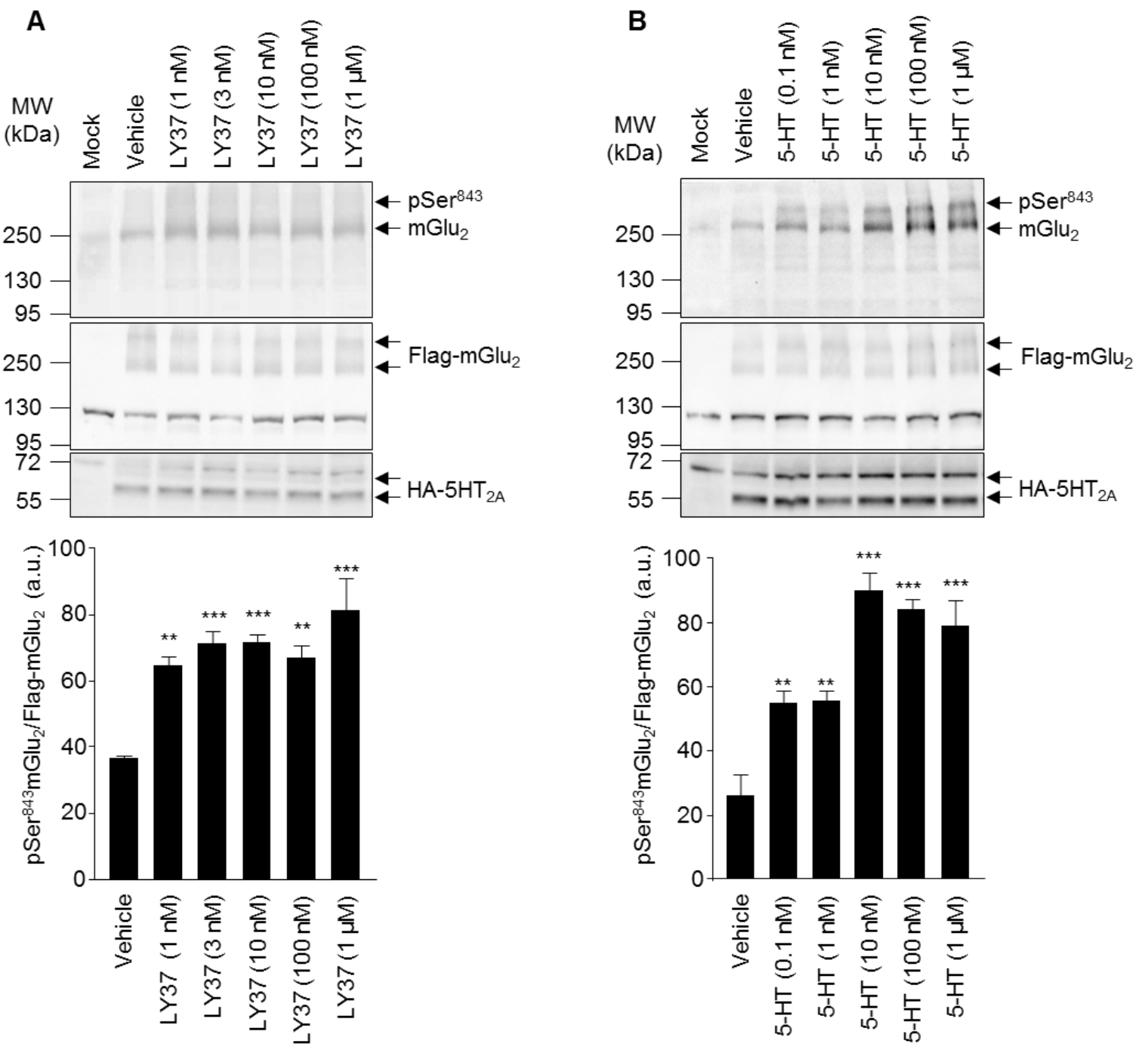

\section{Supplementary Figure 10. Effects of increasing concentrations of LY379268 and 5-HT} on Ser $^{843}$ phosphorylation. A, HEK-293 cells co-expressing Flag-tagged mGlu ${ }_{2}$ receptor and $\mathrm{HA}$-tagged $5-\mathrm{HT}_{2 \mathrm{~A}}$ receptor were exposed to vehicle or increasing concentrations of LY379268 (LY37, 1 nM, 3 nM, 10 nM, 100 nM, 1 MM) for 15 min. B, Cells were exposed to vehicle or increasing concentrations of $5-\mathrm{HT}(0.1 \mathrm{nM}, 1 \mathrm{nM}, 10 \mathrm{nM}, 100 \mathrm{nM}, 1 \mu \mathrm{M})$ for 15 min. Phosphorylation of $\mathrm{mGlu}_{2}$ receptor at $\mathrm{Ser}^{843}$ was assessed by immunoblotting with the anti-phospho-Ser ${ }^{843}-\mathrm{mGlu}_{2}$ receptor antibody and $\mathrm{mGlu}_{2}$ receptor expression by immunoblotting with the anti-Flag antibody. Representative blots of three independent experiments performed on different sets of cultured cells are illustrated. The histograms show the means \pm SEM of the anti-phospho-Ser ${ }^{843} \mathrm{mGlu}_{2}$ receptor immunoreactive signal relative to Flag immunoreactive signal (expressed in arbitrary units, a.u.). One-way ANOVA (Post-hoc: Dunnett's range test): $A, F(5,12)=9.884, p=0.0005$. $B, F(5,12)=20.46, p<0.0001$. ${ }^{*} \mathrm{p}<0.05$ vs. corresponding vehicle conditions. 


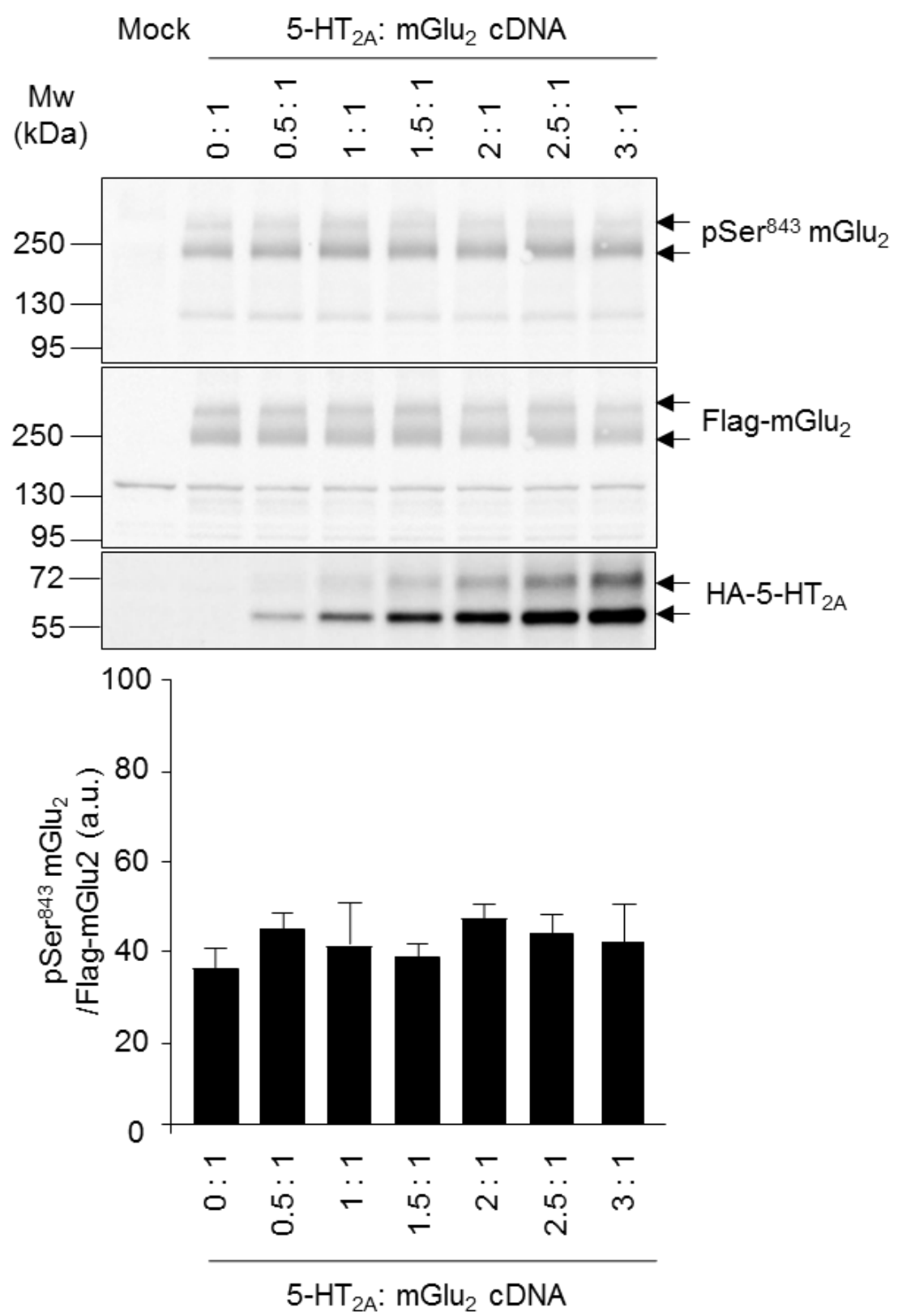

Supplementary Figure 11. Basal $\mathrm{mGlu}_{2}$ receptor $\mathrm{Ser}^{843}$ phosphorylation level does not depend on 5-HT $2 \mathrm{~A}$ receptor expression level. HEK-293 cells co-expressing rat Flagtagged $\mathrm{mGlu}_{2}$ receptor and increasing amounts of $\mathrm{HA}$-tagged $5-\mathrm{HT}_{2 \mathrm{~A}}$ receptor were challenged with vehicle or LY379268 for $15 \mathrm{~min}$. Phosphorylation of $\mathrm{mGlu}_{2}$ receptor at $\mathrm{Ser}^{843}$ was assessed by sequential immunoblotting with the anti-phospho-Ser ${ }^{843}-\mathrm{mGlu}_{2}$ receptor antibody and with the anti-Flag antibody. Representative blots of three independent experiments performed on different sets of cultured cells are illustrated. The histograms show the means \pm SEM of the anti-phospho-Ser ${ }^{843} \mathrm{mGlu}_{2}$ receptor immunoreactive signal relative to Flag immunoreactive signal (expressed in arbitrary units, a.u.). One-way ANOVA (Post-hoc: Tukey's range test): $F(6,14)=0.4493, p=0.8338$. 


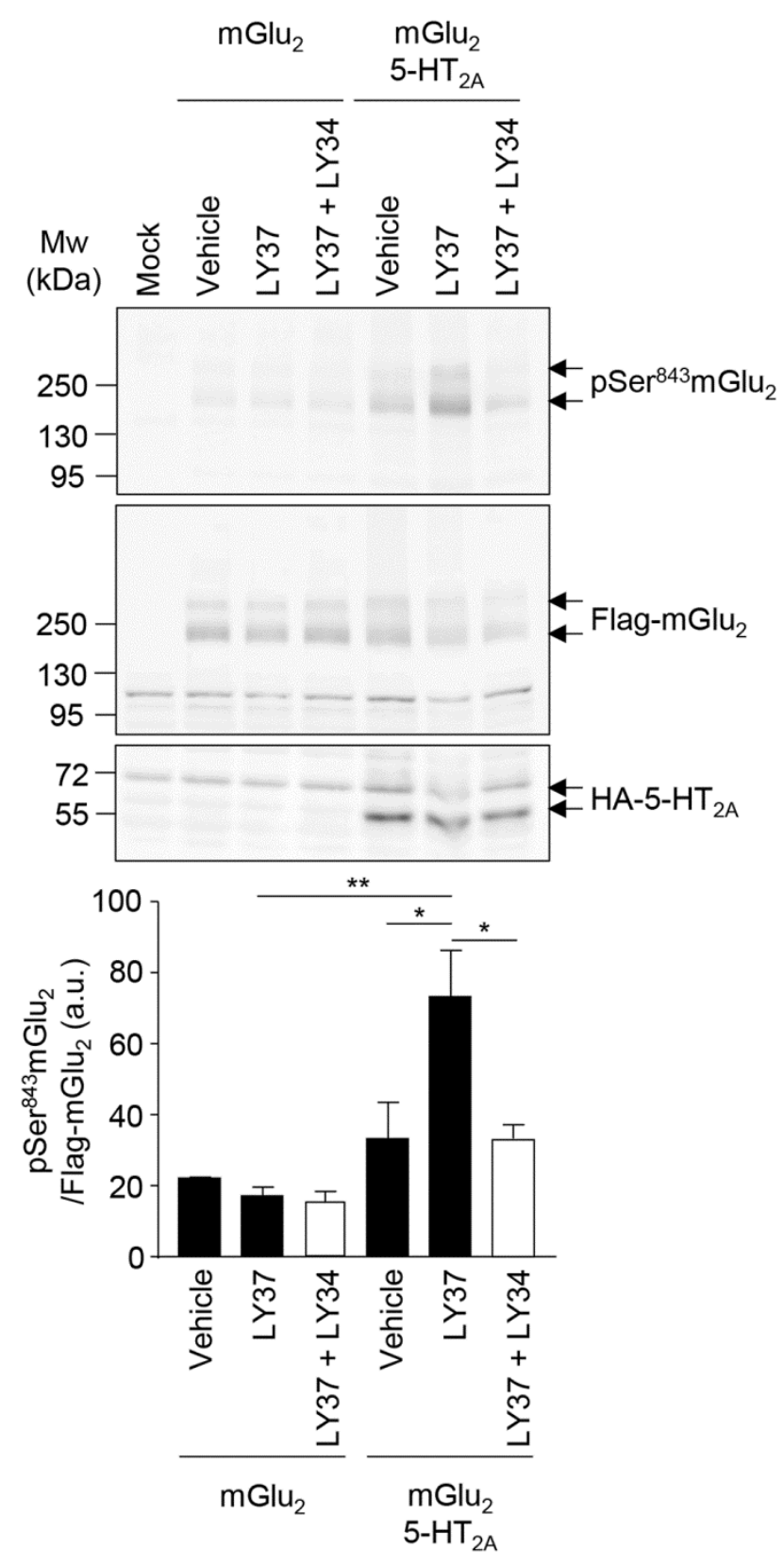

Supplementary Figure 12. LY379268-elicited $\mathrm{mGlu}_{2}$ receptor phosphorylation at Ser ${ }^{843}$ in cells co-expressing $5-\mathrm{HT}_{2 \mathrm{~A}}$ receptor is prevented by the $\mathrm{mGlu}_{2}$ receptor antagonist LY341495. HEK-293 cells transiently expressing rat Flag-tagged $\mathrm{mGlu}_{2}$ receptor alone or in combination with HA-tagged 5- $\mathrm{HT}_{2 \mathrm{~A}}$ receptor were exposed to vehicle or LY379268 (LY37, $10 \mathrm{nM}$ ), in absence or presence of LY341495 (LY34, $10 \mu \mathrm{M})$ for $15 \mathrm{~min}$. mGlu 2 receptor phosphorylation was analyzed by sequential immunoblotting with the anti-phospho-Ser ${ }^{843}$ antibody and the anti-Flag antibody. Representative blots of three independent experiments performed on different sets of cultured cells are illustrated. The histograms show the means \pm SEM of the anti-phospho-Ser ${ }^{843} \mathrm{mGlu}_{2}$ receptor immunoreactive signal relative to Flag immunoreactive signal (expressed in arbitrary units, a.u.) obtained in the three experiments. One-way ANOVA (Post-hoc: Tukey's range test): $F(5,12)=8.407, \quad p=0.0013$. ${ }^{*} p<0.05$; ${ }^{* *} \mathrm{p}<0.01$. 


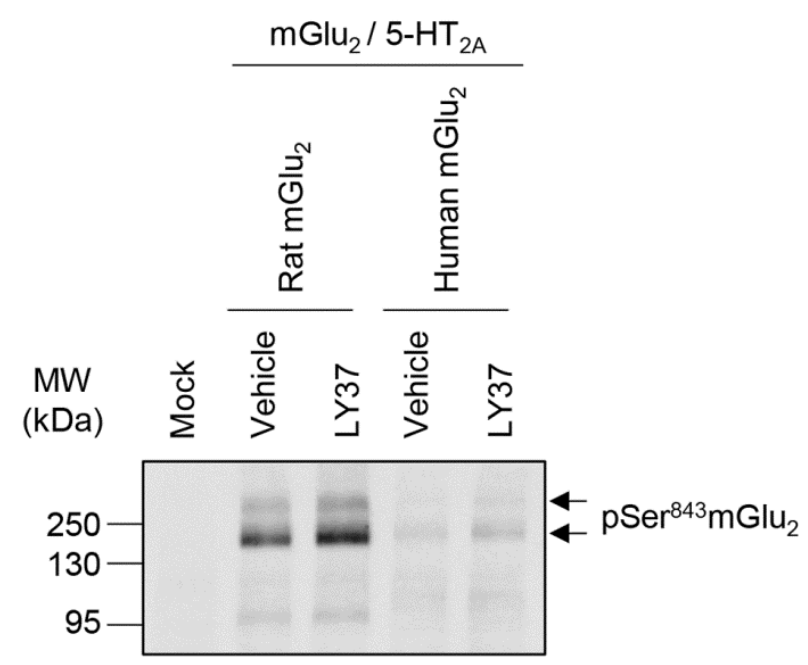

Supplementary Figure 13. Western blot analysis of rat and human $\mathrm{mGlu}_{2}$ receptor phosphorylation at Ser ${ }^{843}$. HEK-293 cells co-expressing HA-tagged 5- $\mathrm{HT}_{2 \mathrm{~A}}$ receptor and either rat or human Flag-tagged mGlu $_{2}$ receptor were exposed to vehicle or LY379268 $(\mathrm{LY} 37,1 \mu \mathrm{M})$ for $15 \mathrm{~min}$. The phosphorylation of rat and human $\mathrm{mGlu}_{2}$ receptor at $\mathrm{Ser}^{843}$ was analyzed by Western blotting using the newly generated anti-phospho-Ser ${ }^{843} \mathrm{mGlu}_{2}$ receptor antibody. Note that LY379268 treatment increased the immunoreactive signal of both rat and human orthologs, but the signal intensity was much higher for the rat receptor. 


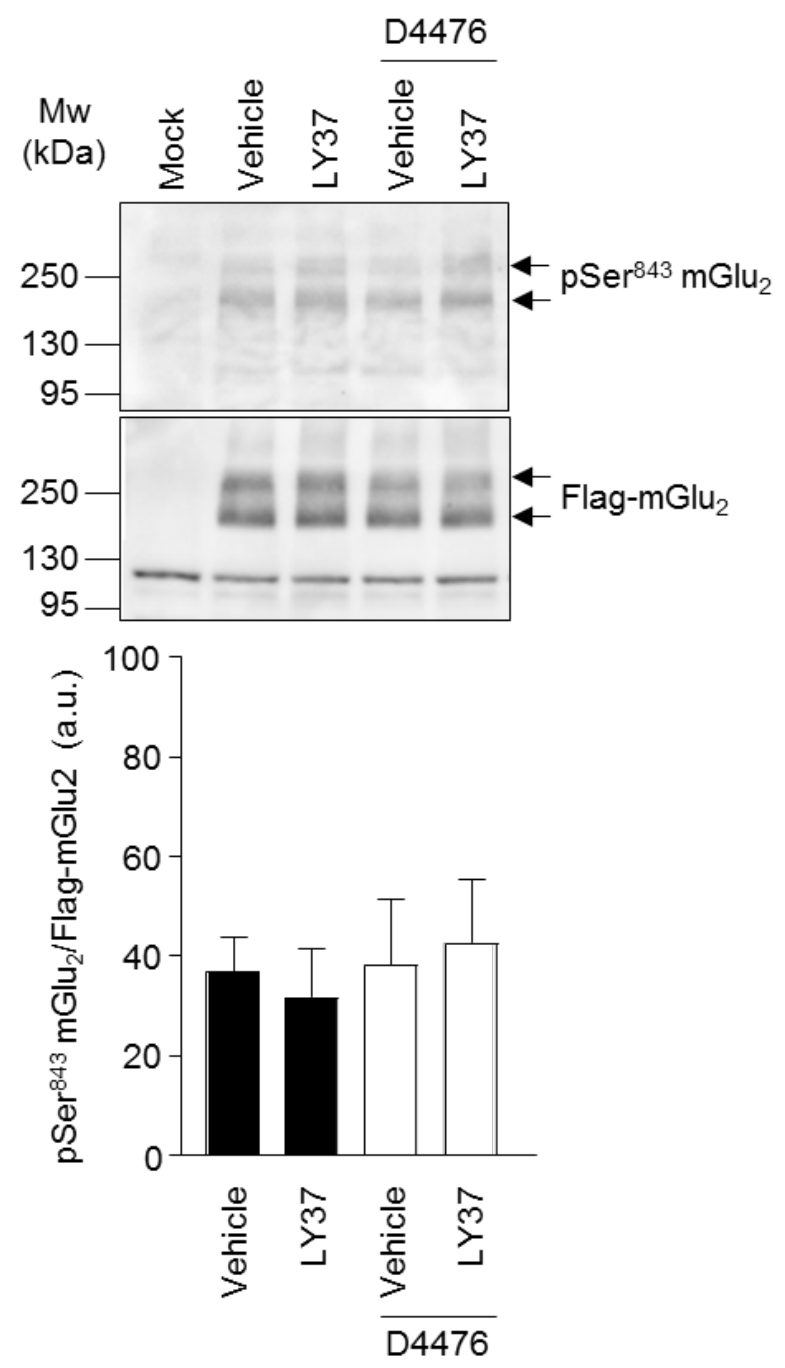

Supplementary Figure 14. LY379268-induced $\operatorname{Ser}^{843}$ phosphorylation in cells expressing mGlu $_{2}$ receptor alone is not mediated by casein kinase 1 . HEK-293 cells expressing rat Flag-tagged $\mathrm{mGlu}_{2}$ alone were pre-incubated with either vehicle or the CK1 inhibitor (D4476, $10 \mu \mathrm{M}$ ) for 60 min and then challenged with vehicle or LY379268 (LY37, 1 $\mu \mathrm{M}$ ) for $15 \mathrm{~min}$. Phosphorylation of $\mathrm{mGlu}_{2}$ receptor at $\mathrm{Ser}^{843}$ was assessed by sequential immunoblotting with the anti-phospho-Ser ${ }^{843}-\mathrm{mGlu}_{2}$ receptor antibody and the anti-Flag antibody. Representative blots of three independent experiments performed on different sets of cultured cells are illustrated. The histograms show the means \pm SEM of the anti-phospho$\mathrm{Ser}^{843} \mathrm{mGlu}_{2}$ receptor immunoreactive signal relative to Flag immunoreactive signal (expressed in arbitrary units, a.u.) obtained in the three experiments. One-way ANOVA (Post-hoc: Tukey's range test): $F(3,8)=0.1738, p=0.9112$ 

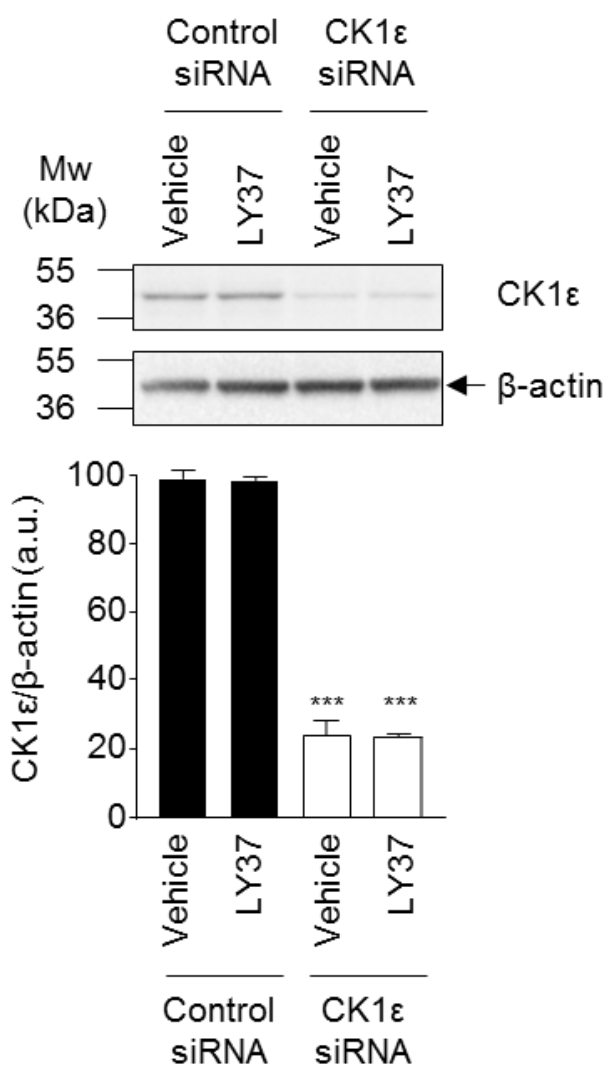

Supplementary Figure 15. Silencing casein kinase $1 \varepsilon(C K 1 \varepsilon)$ expression in HEK-293 cells by RNA interference. HEK-293 cells co-expressing rat Flag-tagged mGlu 2 and HA-

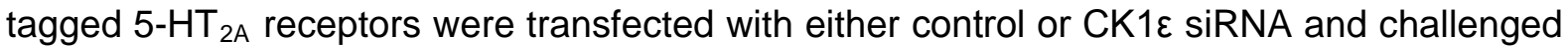
with vehicle or LY379268 (LY37, $1 \mu \mathrm{M})$ for $15 \mathrm{~min}$. CK1 $\varepsilon$ protein expression was assessed by sequential immunoblotting with the anti-CK1 $1 \varepsilon$ antibody and the anti- $\beta$-actin antibody. Representative blots of three independent experiments performed on different sets of cultured cells are illustrated. The histograms show the means \pm SEM (expressed in arbitrary

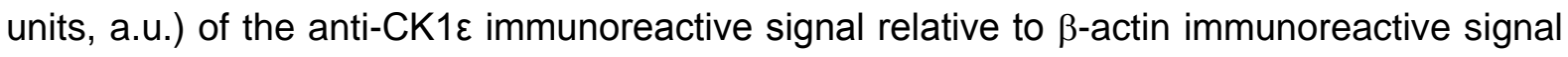
obtained in the three experiments. One-way ANOVA (Post-hoc: Tukey's range test): $F(3$, $8)=230, p<0.0001$. ${ }^{\star \star *} p<0.001$ vs. corresponding condition in presence of control siRNA. 

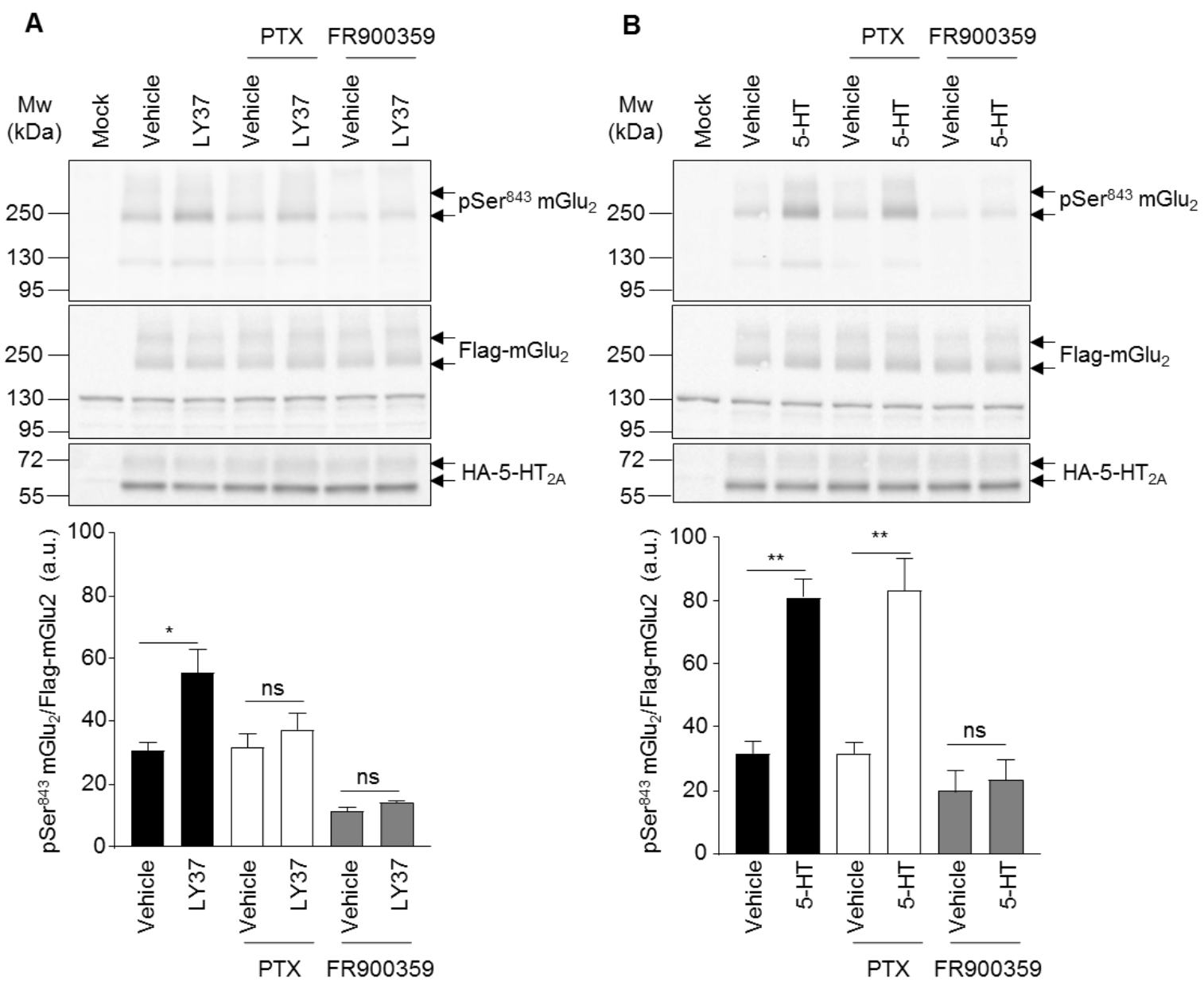

Supplementary Figure 16. Role of $G_{i / o}$ and $G_{q}$ proteins in the phosphorylation of mGlu $_{2}$ receptor at Ser ${ }^{843}$. A, HEK-293 cells co-expressing rat Flag-tagged mGlu ${ }_{2}$ and HAtagged $5-\mathrm{HT}_{2 \mathrm{~A}}$ receptors were pre-incubated with either vehicle or Pertussis toxin (PTX, 0.1 $\mu \mathrm{g} / \mathrm{mL}, 18 \mathrm{~h})$ or FR900359 (1 $\mu \mathrm{M}, 2 \mathrm{~h})$ and challenged with either vehicle or LY379268 (LY37, $1 \mu \mathrm{M}, 15$ min). B, HEK-293 cells were challenged with either vehicle or 5-HT (1 $\mu \mathrm{M}$, $15 \mathrm{~min}$ ). Phosphorylation of $\mathrm{mGlu}_{2}$ receptor at $\mathrm{Ser}^{843}$ was assessed by immunoblotting with the anti-phospho-Ser ${ }^{843}-\mathrm{mGlu}_{2}$ receptor antibody and $\mathrm{mGlu}_{2}$ receptor expression by immunoblotting with the anti-Flag antibody. Representative blots of three independent experiments performed on different sets of cultured cells are illustrated. The histograms show the means \pm SEM of the anti-phospho-Ser ${ }^{843} \mathrm{mGlu}_{2}$ receptor immunoreactive signal relative to Flag immunoreactive signal (expressed in arbitrary units, a.u.). One-way ANOVA (Post-hoc: Tukey's range test): $A, F(5,12)=14.82, p<0.0001 . B, F(5,12)=17.37, p<0.0001$. ${ }^{*} p<0.05 ;{ }^{* \star} p<0.01$ vs. corresponding vehicles. 

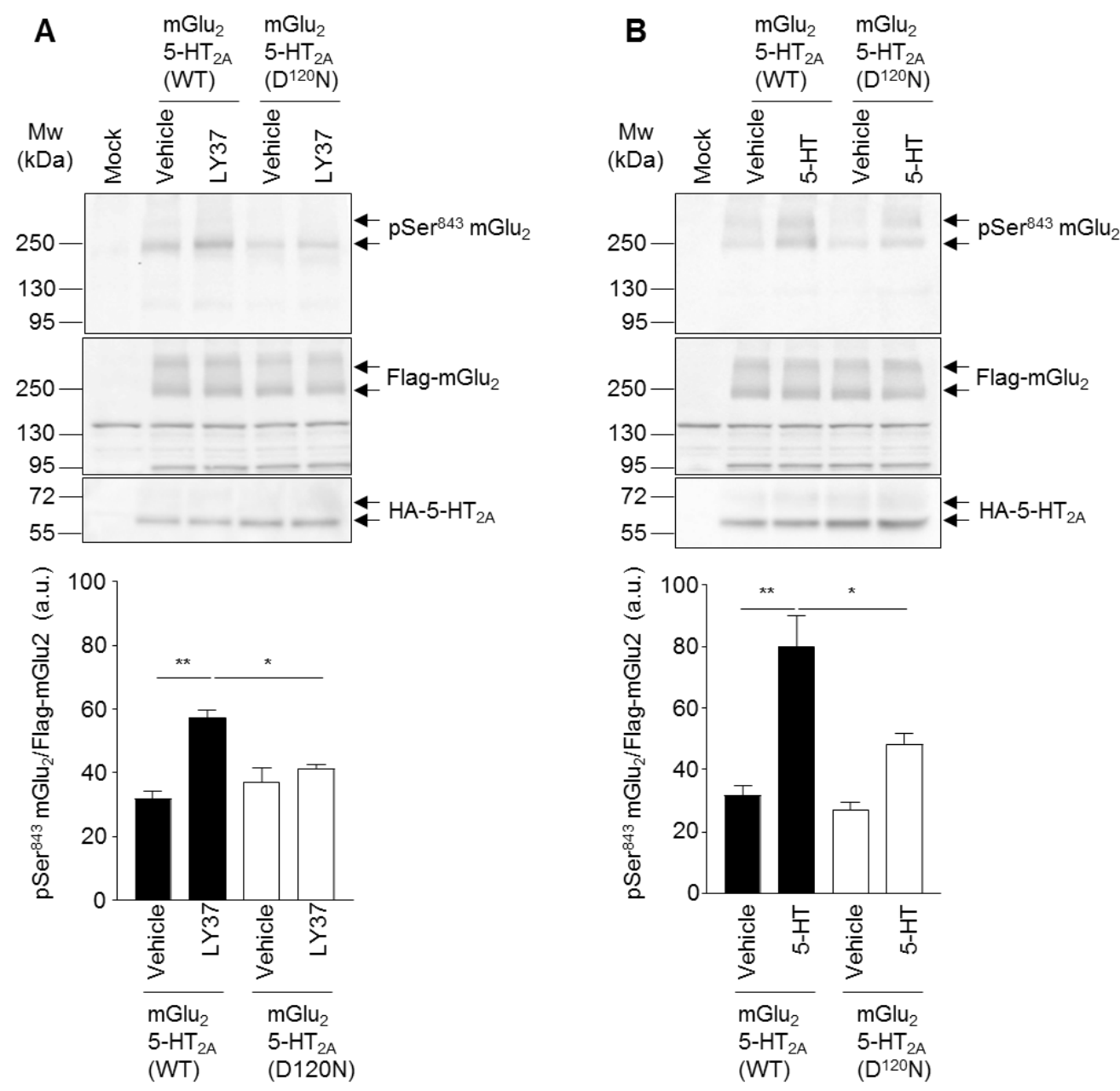

Supplementary Figure 17. Neither LY379268 nor 5-HT promote Ser ${ }^{843}$ phosphorylation in cells expressing $G_{q}$ signaling-dead $D^{120} N 5-H_{2 A}$ receptor. $A$, HEK-293 cells coexpressing rat Flag-tagged $\mathrm{mGlu}_{2}$ in combination with $\mathrm{HA}$-tagged wild type or $\mathrm{D}^{120} \mathrm{~N} 5-\mathrm{HT}_{2 \mathrm{~A}}$ receptor were treated with either vehicle or LY379268 (LY37, $1 \mu \mathrm{M})$ for 15 min. B, HEK-293 cells were treated with either vehicle or $5-\mathrm{HT}(1 \mu \mathrm{M})$ for $15 \mathrm{~min}$. Phosphorylation of $\mathrm{mGlu}_{2}$ receptor at $\operatorname{Ser}^{843}$ was assessed by immunoblotting with the anti-phospho-Ser ${ }^{843}-\mathrm{mGlu}_{2}$ receptor antibody and $\mathrm{mGlu}_{2}$ receptor expression by immunoblotting with the anti-Flag antibody. Representative blots of three independent experiments performed on different sets of cultured cells are illustrated. The histograms show the means \pm SEM of the anti-phospho$\mathrm{Ser}^{843} \mathrm{mGlu}_{2}$ receptor immunoreactive signal relative to Flag immunoreactive signal (expressed in arbitrary units, a.u.). One-way ANOVA (Post-hoc: Tukey's range test): A, $F(3,8)=14.92, p=0.0012$. $B, F(3,8)=17.79, p=0.0007$. ${ }^{*} p<0.05 ;{ }^{* *} p<0.01$ vs. corresponding vehicles. 

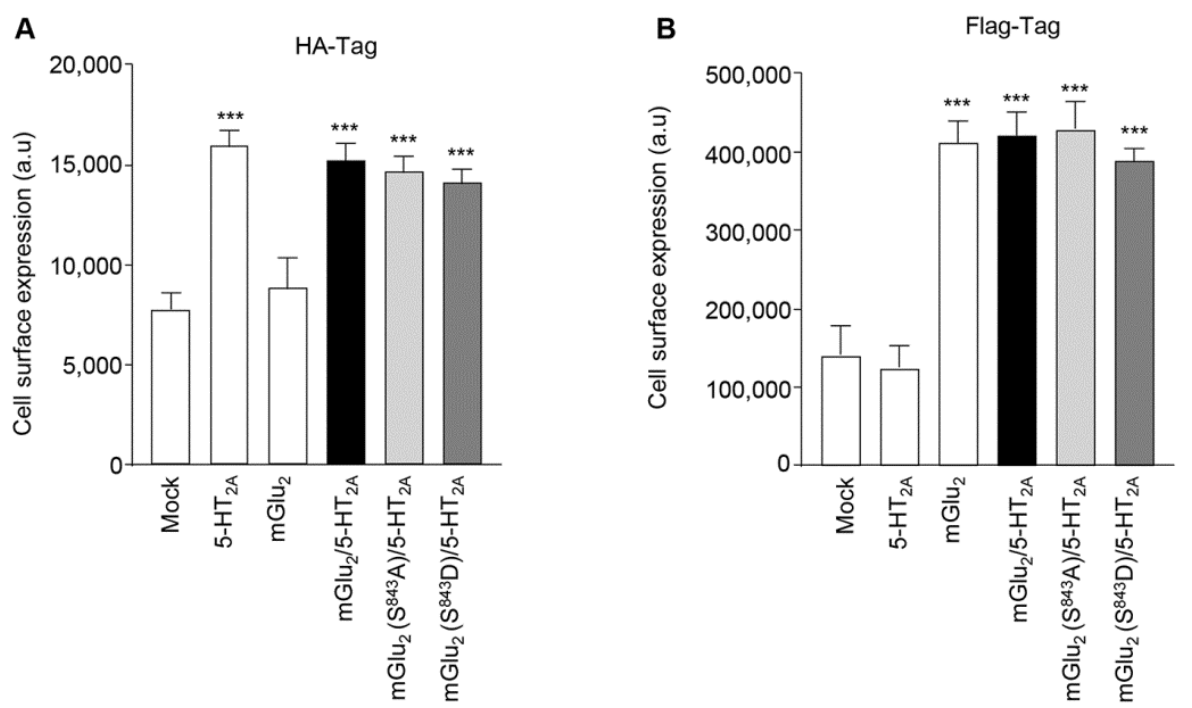

Supplementary Figure 18. $\operatorname{Ser}^{843}$ phosphorylation does not affect cell surface expression of $\mathrm{mGlu}_{2}$ and $5-\mathrm{HT}_{2 \mathrm{~A}}$ receptors. Quantification of cell surface expression of HA-tagged 5- $\mathrm{HT}_{2 \mathrm{~A}}$ receptors $(\mathrm{A})$ and Flag-tagged $\mathrm{mGlu}_{2}$ receptors $(\mathrm{B})$ was performed by ELISA in non-permeabilizing conditions using anti-HA and anti-Flag antibodies, respectively, in cells expressing $5-\mathrm{HT}_{2 \mathrm{~A}}$ or wild type $\mathrm{mGlu}_{2}$ receptor alone or $5-\mathrm{HT}_{2 \mathrm{~A}}$ receptor in combination with either wild type or $\mathrm{S}^{843} \mathrm{~A}$ or $\mathrm{S}^{843} \mathrm{D} \mathrm{mGlu}_{2}$ receptor. Data are the means \pm SEM of values obtained in three independent experiments. One-way ANOVA (Post-hoc: Tukey's range test): $A, F(5.48)=12.97, p<0.0001 ; B, F(5.48)=23.64 . p<0.0001 .{ }^{* \star *} p<0.001$ vs. cells transfected with empty vectors (Mock). 